\title{
Archaeological Studies for the San Antonio Channel Improvement Project, including Investigations at Guenther's Upper Mill
} (41BX342)

Anne A. Fox

Lois M. Flynn

I. Waynne Cox

Follow this and additional works at: https://scholarworks.sfasu.edu/ita

Part of the American Material Culture Commons, Archaeological Anthropology Commons, Environmental Studies Commons, Other American Studies Commons, Other Arts and Humanities Commons, Other History of Art, Architecture, and Archaeology Commons, and the United States History Commons

Tell us how this article helped you.

This Article is brought to you for free and open access by the Center for Regional Heritage Research at SFA ScholarWorks. It has been accepted for inclusion in Index of Texas Archaeology: Open Access Gray Literature from the Lone Star State by an authorized editor of SFA ScholarWorks. For more information, please contact cdsscholarworks@sfasu.edu. 


\section{Archaeological Studies for the San Antonio Channel Improvement Project, including Investigations at Guenther's Upper Mill (41BX342)}

\section{Creative Commons License}

\section{(c) (1) (8)}

This work is licensed under a Creative Commons Attribution-NonCommercial 4.0 International License 


\section{ARCHAEOLOGICAL STUDIES FOR THE SAN ANTONIO CHANNEL IMPROVEMENT PROJECT, INCLUDING INVESTIGATIONS AT GUENTHER'S UPPER MILL (41 BX 342)}

Anne A. Fox, Lois M. Flynn, and I. Waynne Cox

With A Contribution By Robert Harrison

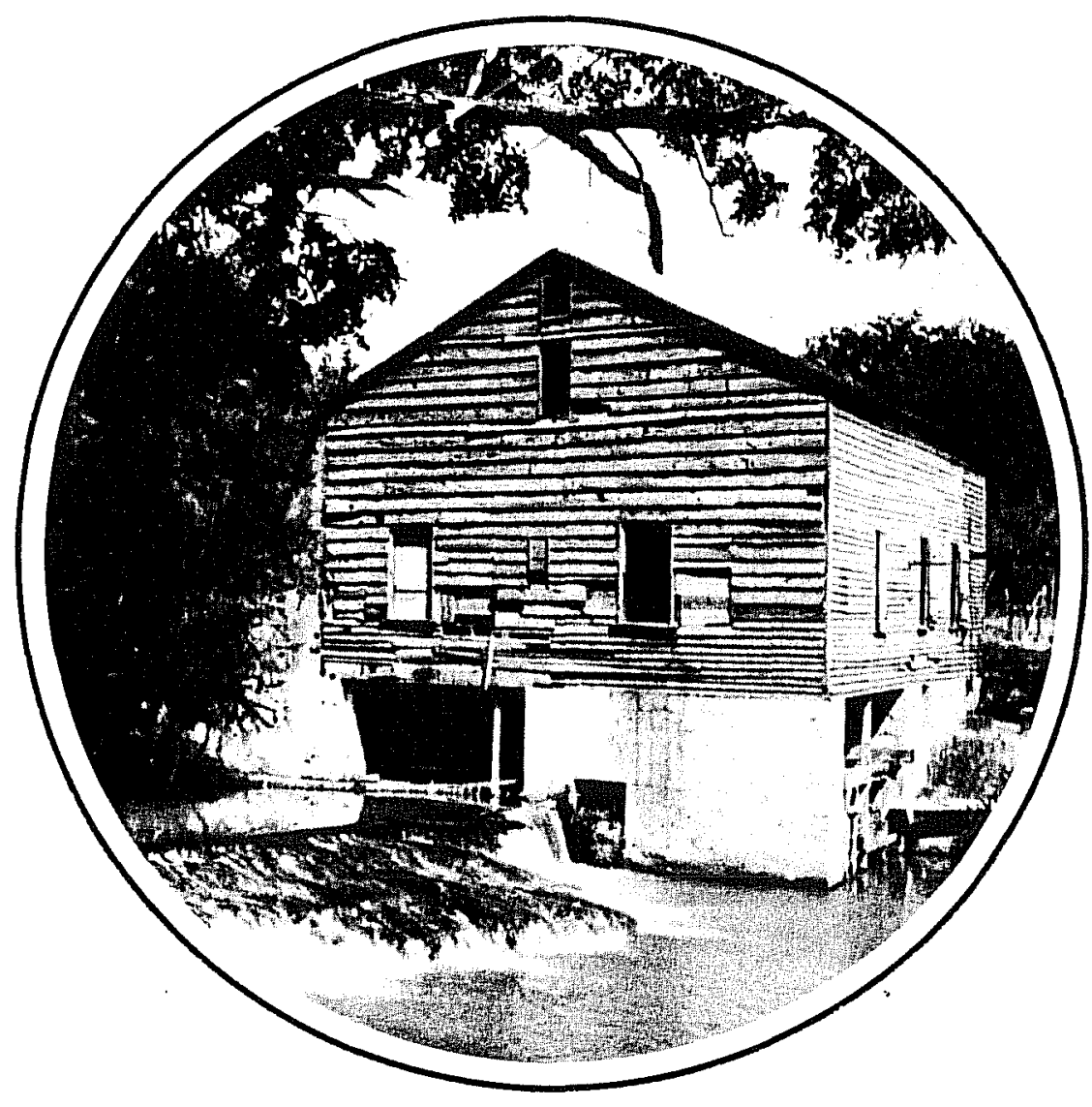

Center for Archaeological Research The University of Texas at San Antonio Archaeological Survey Report, No. 136 



\section{ARCHAEOLOGICAL STUDIES FOR THE \\ SAN ANTONIO CHANNEL IMPROVEMENT PROJECT, \\ INCLUDING INVESTIGATIONS AT \\ GUENTHER'S UPPER MILL (41 BX 342)}

Anne A. Fox, Lois M. Flynn, and I. Waynne Cox

With a contribution by Robert Harrison

Department of the Army, Corps of Engineers,

Fort Worth District, Contract No. DACW63-81-C-0022

Texas Antiquities Committee Permit No. 272

Report prepared under the supervision of

Thomas R. Hester, Principal Investigator

Center for Archaeological Research

The University of Texas at San Antonio (i)

Archaeological Survey Report, No. 136 
The following information is provided in accordance with Generat Rules of Practice and Procedure Chapter 41.11 (Investigation Reports), Texas Antiquities Committee:

1. Type of investigation: archaeological survey and testing and historical research along the San Antonio River;

2. Project name: San Antonio Channe1 Improvement Project, Unit 8-3-2;

3. County: Bexar County, Texas;

4. Principal Investigator: Thomas R. Hester; Co-Principal Investigators: Jack D. Eaton and Anne A. Fox; and Field Director: Lois M. Flynn;

5. Name and location of sponsoring agency: Department of the Army, Corps of Engineers, Fort Worth District, Fort Worth, Texas;

6. Texas Antiquities Committee Permit No. 272;

7. Published by the Center for Archaeological Research, The University of Texas at San Antonio, San Antonio, Texas 782850658, 1987.

A list of publications offered by the Center for Archaeological Research can be obtained by sending $\$ 1.00$ to the Center for Archaeological Research, The University of Texas at San Antonio, San Antonio, Texas 78285-0658. 


\section{ABSTRACT}

Under Contract No. DACW63-81-C-0022 to the Department of the Army, Corps of Engineers, Fort Worth District, the Center for Archaeological Research, The University of Texas at San Antonio, in the spring of 1981, conducted historic research and survey in the areas to be affected by the San Antonio Channel Improvement Project. In the summer of 1981, extensive archaeological testing and excavation were done to determine the extent of the structural remains on the sites of Guenther's Upper Mill and the Stribling House. In the spring and summer of 1982, the Center documented the removal and replacement of the mi11's west wa11.

As a result of the investigations, it can now be affirmed that most of the foundation of the east section of the mill is still present beneath the ground. The main foundation walls are made of cut 7 imestone and measure two feet in thickness, except for the west wall which is three feet thick. of the other buildings at various times related to the mill, only portions of a late (ca. 1910) stone and cement foundation for the Reigler Creamery still remain in the ground. The survey revealed no other cultural resources to be affected by the project. 

ABSTRACT

LIST OF FIGURES

LIST OF TABLES

ACKNOWLEDGMENTS

I. INTRODUCTION

SCOPE OF WORK

RESEARCH DESIGN

METHODOLOGY.

ORGANIZATION OF THE REPORT

II. THE RIVER VALLEY

THE SAN ANTONIO RIVER

III. MILLS AND MILLING IN 19TH-CENTURY TEXÁ

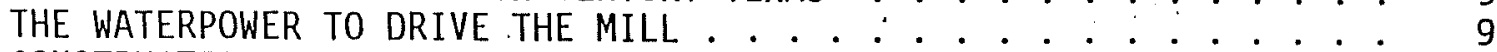

CONSTRUCTION OF THE MILL . . . . . . . . . . . . . . . . . . . . . 10

GRINDING . . . . . . . . . . . . . . . . . . . . . 13

THE MILLSTONES . . . . . . . . . . . . . . . . . . . . . . . . . . . 15

SOCIAL ASPECTS OF THE MILL . . . . . . . . . . . . . . . . . . . . 16

THE MILLER . . . . . . . . . . . . . . . . . . . . . . . 16

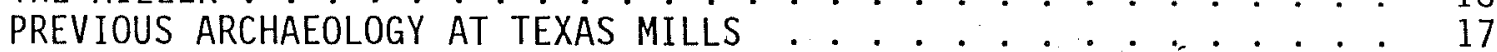

IV. HISTORY OF GUENTHER'S UPPER MILL . . . . . . . . . . . . . . . . . . . 19

OWNERSHIP HISTORY . . . . . . . . . . . . . . . . . . . . . . . 19

THE GUENTHER MILLS . . . . . . . . . . . . . . . . . . . . . 21

V. ARCHAEOLOGY AT THE MILL SITE . . . . . . . . . . . . . . . . . 35

SURFACE SURVEY AND SHOVEL TESTS . . . . . . . . . . . . . . 35

PRELIMINARY WORK AT THE MILL SITE . . . . . . . . . . . . . . . . . 37

THE MILL EXCAVATIONS ....................... . . 39

Unit 1....................... 39

Area A . . . . . . . . . . . . . . . . . . 41

Area B ...................... 42

Unit 2................... . . . 42

Unit 4...................... 44

Unit 3..................... 44

Unit 5..................... 44

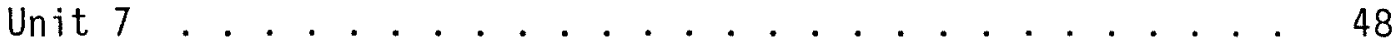

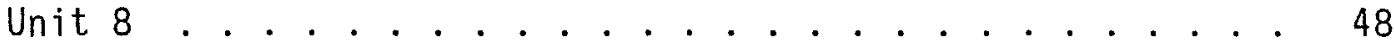

SEARCH FOR THE RETAINING WALL TO THE SOUTH . . . . . . . . . . . . 50

WAREHOUSE AND OFFICE INVESTIGATIONS . . . . . . . . . . . . . . . 50

Unit $6 . . . . . . . . . . . . . .550$

Unit 9....................... . 52

Unit 21....................... 52

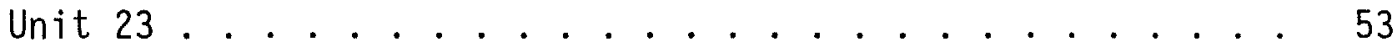

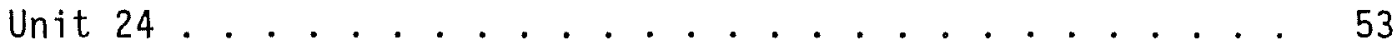

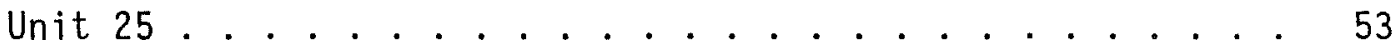

MACARONI FACTORY INVESTIGATIONS . . . . . . . . . . . . . . 53

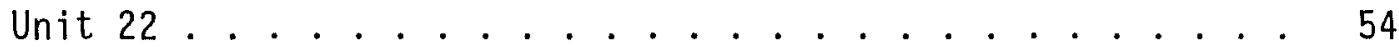

RIEGLER CREAMERY INVESTIGATIONS . . . . . . . . . . . . . . . . 54

Units 9-15 .. . . . . . . . . . . . . . . . . . 54

THE STRIBLING HOUSE INVESTIGATIONS . . . . . . . . . . . . . . 57

Unit 16 . . . . . . . . . . . . . . . . . . . 57

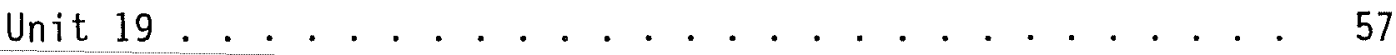

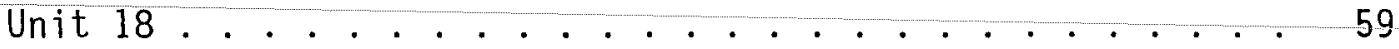


This page has been

redacted because it

contains restricted

information. 


\section{LIST OF FIGURES}

1. Location Maps .. . . . . . . . . . . . . . . . . . . . . . . 2

2. Composite Map of Mill Site, Showing Pre-Channelization and Post-Channelization Contours . . . . . . . . . . . . 8

3. Various Types of Water Wheel Installation . . . . . . . . . . . 12

4. Diagram of Mill Operation ................... . 14

5. Ownership History of Mill Area . . . . . . . . . . . . . . 20

6. Guenther's Upper Mill in the 1870s . . . . . . . . . . . . . . . 25

7. Sanborn's Insurance Map of 1885 and 1888 . . . . . . . . . . . . 26

8. Guenther's Upper Mill in 1888 . . . . . . . . . . . . . . . . . . 29

9. Sanborn's Insurance Map of 1896 . . . . . . . . . . . . . . . . . . 30

10. Sanborn's Insurance Map of 1904 . . . . . . . . . . . . . . . . . 32

11. Sanborn's Insurance Map of 1912 . . . . . . . . . . . . . . . . . 33

12. Guenther's Upper Mi11 in the 1920s . . . . . . . . . . . . . . . . 34

13. The Mill Site at the Start of Investigations . . . . . . . . . . . 38

14. Plan Map of Relationship of Excavation Units . . . . . . . . . . . 40

15. Views of Area B... . . . . . . . . . . . . . . . . . . . 43

16. Foundations of the Mill . . . . . . . . . . . . . . . . . . 45

17. West Wall Profile of Unit 5.................. . 47

18. North Wall Profile of Unit 7 . . . . . . . . . . . . . . . . 49

19. Profiles of Excavation Units 6 and 22 . . . . . . . . . . . . . . 51

20. North Wall Profile of Unit 9 . . . . . . . . . . . . . . . . . 55

21. Plan of Stribling House Excavations, Units 16 and 19 . . . . . . 58

22. Wheel Pit and Forebay Before Clearing, Looking West . . . . . . . . 61

23. Plan of Wheel Pit Timbers . . . . . . . . . . . . . . . . 62

24. Cross Sections .. . . . . . . . . . . . . . . . . 64

25. Record Drawings of West Wall . . . . . . . . . . . . . . 65

26. Removal of Wheel Pit Timbers . . . . . . . . . . . . . . . 67

27. Removing West Wall . . . . . . . . . . . . . . . . . 68

28. Reconstruction of West Wal1................. . . . . 70

29. Millstone..... . . . . . . . . . . . . . . . . 75

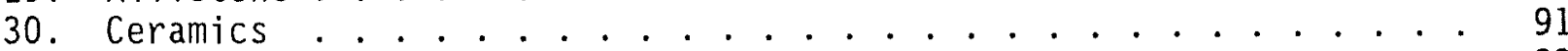

31. Glass Containers . . . . . . . . . . . . . . . . 93

32. Tablewares . . . . . . . . . . . . . . . . . . . 95

33. Miscellaneous Small objects . . . . . . . . . . . . . . . . 97

34. Miscellaneous Tools and Machine Parts... . . . . . . . . . . . 101

\section{LIST OF TABLES}

1. Mills in San Antonio in the 19th Century . . . . . . . . . . . . 28

2. Provenience of Artifacts . . . . . . . . . . . . . . . . . . 87

3. Species List and Specimen Information . . . . . . . . . . . . . 104 


\section{ACKNOWLEDGMENTS}

As with most historical investigations, work started before excavation began and continued long after excavation ended. Every phase of the work has been aided by the help of numerous people to whom we owe thanks.

The research into the history of the Guenther family and the mills was greatly expedited by the cooperation of descendants of the family and by various people who have been connected in one way or another with the operation of the mill over the years. The first and most detailed source of information has been the collection of papers of Ernst Schuchard at the Daughters of the Republic of Texas (DRT) Research Library at the Alamo. These, along with the invaluable book compiled by Mr. Schuchard (1951) on the 100th anniversary of the Pioneer Flour Mills provided important technical and historical information. Also in the collections of the DRT Library is a translation of Carl H. Guenther's diary (Hurst n.d.) which gave us many insights into Guenther's 7 ife and personality. We are grateful to the staff of the library for their help in our research.

Of the many other members of the staff and family of the Guenther mills who offered help, we should single out in particular Anna Laura Beckman and Amanda Ochse who loaned family photographs and personal notebooks of Carl Guenther and numerous mill photographs. These photographs were extremely helpful in attempting to reconstruct the history of the mill buildings. Another person who was most cordial and gracious in his sharing of milling information and photographs was Mr. Brentano Harnisch, formerly treasurer of the Pioneer Flour Mills. We sincerely regret that Mr. Harnish passed away recently and will not see the publication that results from this project.

Mr. Charles Howell, miller in residence at the Philipsburg Manor in Terrytown, New York, and a friend of long standing, has been most helpful in providing technical information and sage advice.

The cooperation of employees of the Department of the Army, Corps of Engineers, Fort Worth District; The San Antonio River Authority; the Texas Historical Commission; and the San Antonio Parks and Recreation Department has resulted in project flexibility and unusually close harmony in decision making for which we are grateful. We are particularly beholden to the patience and good humor of archaeologist Robert Burton and to the helpful suggestions of Stephen $C$. Helfert, Chief of the Environmental Resources Branch of the Fort Worth Corps.

We are grateful, also, to employees of the San Antonio River Authority (SARA) for their help and cooperation. Rebecca Cate and Dorian French deserve special mention.

The personnel of the Rosiek Construction Company were pleasant and helpful. Special thanks to Getty Skinner and Paul Doege for their patience in working around and with our crew in what must have been at times a great nuisance. We are particularly grateful for the skill and dexterity of crane operators Don Westfall and Terry Joe Etzberger. 
Stonemasons from the Wallace Masonry Company of San Antonio were professional and diligent in their work. We particularly thank Tommy Kosub, Nelson Padalecki, Juan Neaves, Chuck Friske, and Ronnie Kosub.

The hard work of the archaeological crew is most appreciated. Full time members were Elaine Brown, I. Waynne Cox, Katherine Gonzales, Betty Markey, Cecil Peel, Joan Sherwood, and Greg Sundborg. There were also numerous volunteers who participated for varying periods of time. Among these we would particularly single out James Ivey for his advice on recording and archaeological approaches, Dixie Watkins for his fine work in recording structures, and Capt. Michael Block, USAF, for excellent photodocumentation of the entire project.

David Hafernik of the Center staff produced the drawings and diagrams for this report. Editors were Sharon Quirk and Elizabeth Gibson, and typists were Ann Young, Mary Lou E1lis, and Mary Lehr. 


\section{INTRODUCTION}

The San Antonio Channel Improvement Project consists of clearing, widening, deepening, and straightening the channel of the San Antonio River and its tributary, San Pedro Creek, in San Antonio and Bexar County, Texas. The project has been undertaken as part of the comprehensive plan of development of the Guadalupe-San Antonio River basin, as authorized by the Flood Control Act of September 3, 1954 (PL 780, 83rd Congress, 2nd Session). The project has been divided into units for efficient implementation. The unit discussed in this report is Unit 8-3-2, which is bounded by Johnson and Nueva Streets and consists of approximately 0.75 miles of the San Antonio River channel (Fig. 1). The unit is a contributing property included within the boundaries of the King Wit7iam Historic District.

The Center for Archaeological Research (CAR) of The University of Texas at San Antonio (UTSA) entered into contract No. DACW63-81-C-0022 with the Department of the Army, Corps of Engineers, Fort Worth District, in April 1981. The contract provided for archaeological and historical assessment, information recovery, and professional recommendations on cultural resources to be affected by the San Antonio Channel Improvement Project. The work was conducted in accordance with the Department of the Army, Corps of Engineers, Fort Worth District's obligation under the National Historic Preservation Act of 1966 (PL 89-665); the National Environmental Policy Act of 1969 (PL 91190); Preservation of Historical and Archeological Data, 1974 (PL 93-291); the Procedures for the Protection of Historical and Cultural Properties (36 CFR VIII Part 800), Advisory Council on Historic Preservation; and Identification and Administration of Cultural Resources (ER 1105-2-460, April 3, 1978) of the Corps of Engineers. Since the unit is also within the City of San Antonio King William Historic District, Permit No. 272 was granted to the Center by the Texas Antiquities Committee.

\section{SCOPE OF WORK}

The scope of work for the cultural resource investigations included a variety of objectives:

1. Survey of the channel edges and evaluation of houses to be affected by the project.

2. Survey of a proposed disposal site for dredged materials.

3. Excavation of the Guenther Upper Mi11 site (41 BX 342).

4. Periodic monitoring of construction work in highly sensitive areas identified during the survey.

5. Guidance on cultural resources affected by the project.

6. Possible resource recovery efforts necessitated by unexpected finds during construction. 


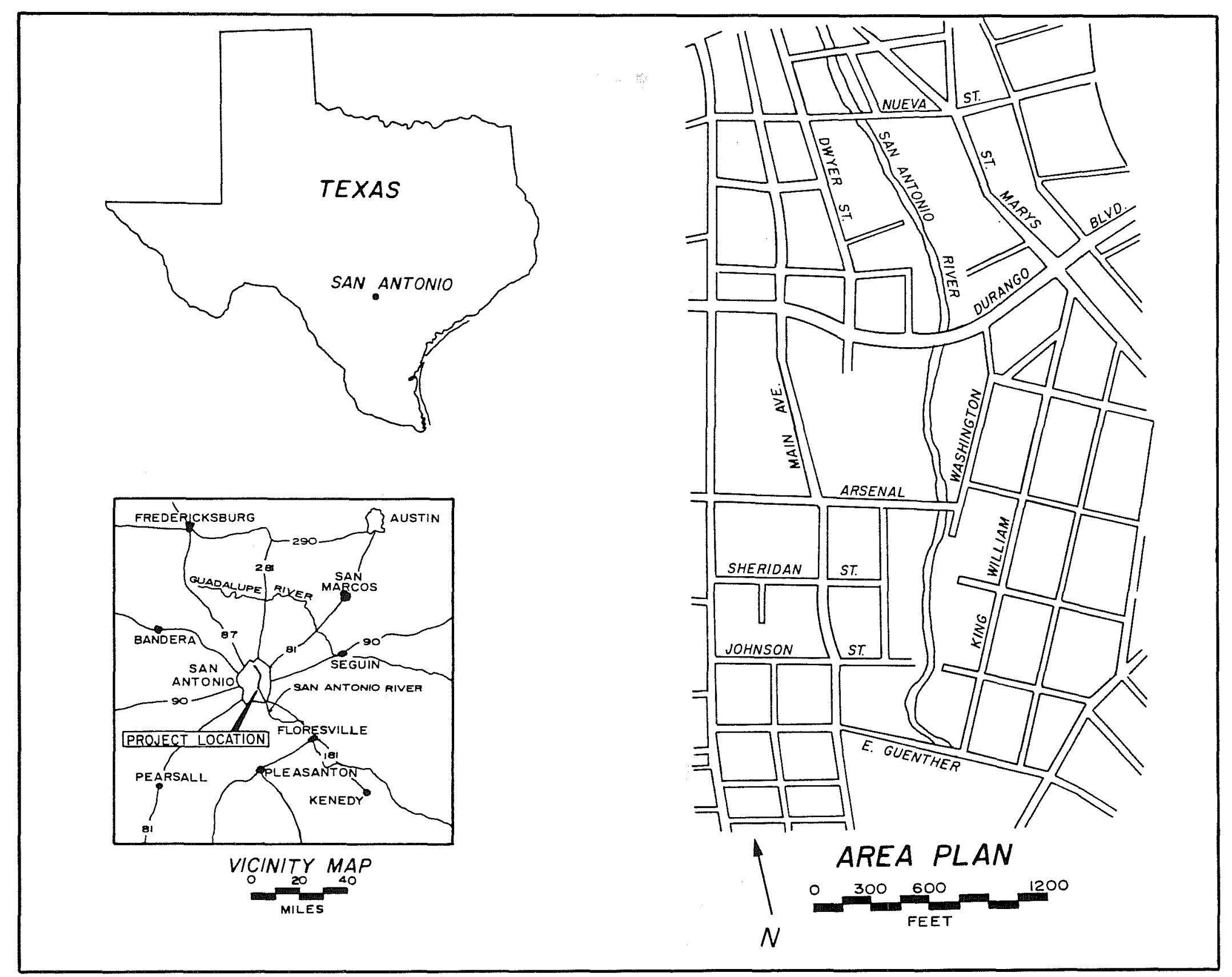

章

Figure 1. Location Maps. 
The intent of the investigations was to address problems important in anthropology and history, and to recover information important not only to local but to regional and national interests (Department of the Army, Corps of Engineers, Fort Worth District 1980:Appendix A). With these goals in mind, a research strategy was designed which would extract the maximum amount of information on Guenther's Upper Mill, in all stages of its existence from construction to the final demolition of the mill building during flood control efforts in 1926. Efforts were also organized to study the mill in relation to its setting on the river, its place in the community, and its importance to the total history of the San Antonio River valley.

\section{RESEARCH DESIGN}

A research design for excavations at Guenther's Upper Mill was submitted to the Department of the Army, Corps of Engineers, Fort Worth District on May 22, 1981. This document outiined plans to conduct testing and excavations to locate and examine the site of the mill itself and other buildings used in relation to it, such as warehouse and office facilities. Any surviving milling equipment still in the river was to be examined and thoroughly documented, and any items that could be feasibly removed would be taken from the water and properly stored. On-site supervision and documentation were to be provided by the archaeologists as the mill foundations were removed from the channel, since they could not remain there during construction. Detailed plans for the actual removal of the foundations were developed after their extent was revealed by the archaeologists.

\section{METHODOLOGY}

The overall methodology for the investigation called first for archival and historical research. This included deed research, collection and copying of all known photographs and maps of the mill property, interviews with officials and employees of Pioneer Flour Mills, Guenther family members and other citizens, extensive study of books on milling, and correspondence with millers and milling experts. After the history of the section of the river between Johnson and Nueva Streets had been reconstructed through research, the survey and excavations began.

The approximate locations of mill buildings were laid out with transit and tape, and excavation was done by stratigraphic levels, using hand tools except where a sufficient depth of overburden warranted the use of shovels. Soil removed, except recent fill, was screened through 1/4-inch mesh. Excavation was done in stratigraphic levels. All measurements were made in the English system (feet/inches), since preliminary measurements suggested that the structures on the site were built in that system (the mill building measured $20 \times 30$ feet, walls were 20, 24, and 36 inches thick). Comparative elevations were controlled and recorded with a transit. The field crew varied in size from eight during the excavation phase to two or three during the removal of the west wall and generally one during the reconstruction of the wall. More than $280 \mathrm{man} /$ days were expended during the field work, approximately 224 during excavation, 10 for survey, 50 on removal of debris and documentation and removal of milt remains, and three or four during 
supervision of replacement of the west wa11. This does not include volunteer time by graduate students and Center employees.

Documentation was done in a professional manner using standard record sheets, and numerous plans and profiles were drawn for each excavation unit. A daily log was kept of all work, and a record was kept for both black and white and color photographs. Artifacts were placed in bags marked with their provenience and were carried each evening to the UTSA campus laboratory where they were washed, marked, and cataloged. Detailed documentation in line drawings and photographs was done of the remnants of the mill in the riverbed. These proved extremely important and useful when it came time to reconstruct the west wall in the finished channel, and also for the interpretation of the workings of the mill during analysis. All photographs, field records, and artifacts are now curated at the laboratory of the Center for Archaeological Research, using standard methods of curation, storage, and retrieval.

\section{ORGANIZATION OF THE REPORT}

It has been difficult to evolve a method of organization for a report which must deal with such a wide variety of types of technical information, description, history, and archaeology. We have arbitrarily divided the body of the report much the way the work progressed from the beginning. Section II contains background information on the geography and history of the San Antonio River itself and its relationship to the 19 th-century town of San Antonio. Section III deals with mills, how they are built and operated, and previous investigations of mills in central Texas.

With these two sets of data, we are then ready in Section IV to introduce Carl Hilmar Guenther and to demonstrate how he, his family, and his mills entered into and helped shape the history of the river and of San Antonio. Section $V$ describes the survey and archaeological investigations, drawing on aspects of the previous sections to explain what was found. Section $V$ also details the removal of all the remaining traces of the mill in the channel, the treatment and storage of the timbers and stone, and the reconstruction of the west foundation wall after the channelization was completed. Section VI summarizes the project and presents our conclusions. Section VII is our recommendations for future modifications at the mill site. Section VIII is a glossary for specific terms pertaining to milling and the architecture thereof.

The production of the report has been a cooperative effort. Lois Flynn, who directed the field work and did by far the largest part of the background research, wrote the recording, demolition, and reconstruction section. Flynn and Fox together wrote the account of the excavations and the historical section. Cox described the survey portion of the project, which he directed, and he contributed substantially to the section on the history of the San Antonio River. Cox also is the author of Appendix III. Fox wrote the Introduction and the Summary and Conclusions, Appendix I, and used the considerable research done by Flynn to compose the section on milling. Robert Harrison is the author of Appendix II, the analysis of the faunal remains from the site. 


\section{THE RIVER VALLEY}

San Antonio and Bexar County are located at the boundary between the Edwards Plateau and the Texas Coastal Plain, and are located on part of the Balcones Fault Zone. Most of the water in the streams of the county flows from the Edwards Aquifer, which extends beneath five counties along the fault zone.

San Antonio has a modified subtropical climate, being continental in the winter and marine in the summer. Average temperatures vary from $53.7^{\circ} \mathrm{F}$ for December through February to $83.2^{\circ} \mathrm{F}$ for June through August. Rainfal1 is heaviest in May and September (Gerstle, Kelly, and Assad 1978:26).

The San Antonio River and its tributary, San Pedro Creek, arise from deep springs within the present city limits. They once carried sufficient water to irrigate the crop lands of a town and five Spanish missions. Although the flow of the springs has severely abated today, the situation of the city within a bowl-shaped valley invites disastrous flooding when heavy rains occur within the watershed.

Soils in the immediate vicinity of the San Antonio River are primarily Trinity and Frio soils. Both soil types are dark colored, alluvial, and relatively fertile. They can support a heavy cover of elm, oak, mesquite, thorny shrubs, and grasses (Southwest Research Institute 1979:n.p.).

\section{THE SAN ANTONIO RIVER}

The interaction of the city of San Antonio with the San Antonio River has been evident from its founding 266 years ago to the present day. The river originates from springs arising from the Edwards Aquifer and has provided moisture to support extensive flora and fauna in an otherwise semiarid landscape. The lush environment must have been an attractive resource to the earliest occupants of this relatively barren area. In fact, occupation by at least 8800 B.C. has been documented in the vicinity (Hester 1980:28). This association of the lands, river, and people formed a continuum that lasted until the arrival of the Spanish. In 1691, Father Massanet celebrated a Mass for Saint Anthony of Padua bestowing the name San Antonio upon both the river and upon the later settlement that was founded there in 1718 (Webb 1952 Vol. II:544).

One of the first acts of the new settlers was to utilize the river by construction of acequias or ditches for irrigation of the fields in the river valley. As a consequence, the town developed a linear, north-south growth pattern along the river valley. Even into the mid-19th century, after the arrival of Anglo-American and German immigrants, this pattern persisted due to their daily needs for water and the demands of their developing industries. The excellent volume of water and fa11 in elevation, 62.05 feet between the head springs and the southern city limits (Reilly 1885), invited its use for more than irrigation.

Near the end of the mission period, the Franciscans had built a grist mill at Mission San José. Just upstream from Mission Concepcion, the Yturri Mi11 apparently was in operation in the early 19th century (Cruse 1985:2), as was the Molino $\bar{B}$ ianco just north of the town (Southern Moving and Storage Co. 1970). 
By mid-century, these Spanish mills were superseded by the mills of newly arrived Anglo-American and German settlers, who used waterpower to drive not only grist and flour mills, but also sawmills, wool scouring machines, and cotton gins.

The symbiotic relationship between the river and the community was not without its cost. Proximity of the river also made the settlement vulnerable to the swift and often devastating floods that periodically transformed their usually tranquil benefactor into a raging torrent.

The first of these floods recorded occurred on March 30, 1779.

Tuesday of Holy week an extraordinarily heavy rain fell on the Missions of Texas. The river and all the streams were flooded. It rained incessantly from $3 \mathrm{pm}$ til $7 \mathrm{pm}$ and damaged gardens and farms. The water reached the patio of Mission San Juan Capistrano (Leutenegger and Habig 1977:15).

Again, in July of 1819, the river revealed the ugly side of its temperament to the little Spanish community:

- . an unusual flood, a cloudburst occurred about 5 o'clock on the morning of the 5 th of this month, and suddenly without the least chance of averting disaster, the torrent of water left its channel and spread over the town with a force beyond imagination; houses were washed from their foundations with the families inside, they were seen to revolve in whirlpools formed by the rushing waters, then lashed by the many logs that the river brought down with fury and violence, said houses began to disappear, leaving only fragments afloat to indicate the disaster that overtook them (Martinez 1819:174).

This flood resulted in total destruction not only in the town but of crops in the fields and storehouses, causing a famine thoughout the following year.

On October 1 and 2, 1845, 7.88 inches of rain fell within 24 hours on San Antonio. The next recorded floods occurred in 1853 and 1865; the 1atter was responsible for a cholera epidemic that took 293 lives. This led to a general clean-up of the city and a recommendation for installation of a water system to take the place of shallow wells and acequias (Herff 1973:71). From midnight July 3 to the morning of July $6,1869,14.5$ inches of rainfall were recorded (Corner 1890:149). Other major floods occurred in 1880, 1883, and 1889.

On October 1, 1913, flood water again swept San Antonio, peaking at 23 to 24 feet above norma1, the greatest in the vicinity since 1853 (Department of the Army, Corps of Engineers, Fort Worth District 1969:26). Four persons lost their lives, and property damage was reported at $\$ 250,000$. There was an immediate outcry of "dam the 0lmos" (San Antonio Express 1913). This flood so alarmed the city of San Antonio that the advice of the consulting engineering firm of Metcalf and Eddy was sought. Their report, completed in December 1920, warned: 
. . the city is constantly facing the menace of disastrous floods. We doubt if the citizens realize the ruinous loss which would result today with the present condition of the river channels, from such a flood as that of a century ago. When such a flood will recur, no man can say. But that it will recur is certain (SARA 1970:1).

The predicted flood occurred the following year on Saturday night September 10, 1921. The morning paper grimly announced, "River rise brings widespread loss, caught unaware, sleeping scores are suddenly swept off" (San Antonio Express 1921). The final estimates indicate a loss of 49 dead, 14 missing, and $\$ 8,000,000$ in property damage (SARA 1969:26).

After this disaster, there was little opposition to the adoption of a river control plan. The plan called for the re-channelization of certain reaches of the San Antonio River (see Fig. 2) and San Pedro, Alazan, Martinez, and Apache Creeks, as well as the 1ong-requested 01mos Creek Dam, at a cost of $\$ 4,555,000$ (SARA 1970:2). Work on the project continued over the next 19 years, but came to a halt with the onset of World War II. The events on September 16, 1946 demonstrated that the work had not been adequate. On this day a cold air mass stalled over the city and struck moisture-laden Gulf air currents; the resulting storm drenched the city with 10 inches of rain. Total damage to the city was reported at $\$ 8,000,000$ and the loss of 10 lives (Department of the Army, Corps of Engineers, Fort Worth District 1969:26).

In 1949, the State Legislature appropriated the state ad valorem tax from Bexar, Wilson, Karnes, and Goliad Counties to be used to straighten the channel at Ninth Street and to finance the Tainter Gate between Commerce and Market Streets (SARA 1970:6). Two additional floods in May and December showed that those areas that had received channel improvements could adequately protect their banks, but also dramatically indicated that unimproved portions of the project were still vulnerable. In addition, due to extensive runoff from urbanization of the San Antonio watershed, the Berg's Mill area was heavily struck. The high-intensity runoff was safely carried through the city's new flood channel, but spilled out of the natural channel when it reached the Ashley Road bridge. The unprotected residents of the area expressed urgent concern to have the project extended through Berg's Mi11 and south of I.H. 410. Such improvements were also required in order to protect Mission San Juan Capistrano (SARA 1980:9). This was accomplished, the project being extended through that area during the following few years.

Concern for the unprotected portions of the county also prompted the following actions. Structural modifications and the reinforcement of 01 mos Dam were completed in July 1981. The Corps of Engineers channelized the Piedras (Six Mile) Creek in such a manner as to protect the historic aquaduct at Mission Espada during high water and yet still allow the creek to flow during normal periods. The San Antonio River Authority (SARA) is currently constructing the Nueva Street Marina and Flood Control Dam, which will provide a docking facility for barges and patrol boats. The marina will also provide barge maintenance shops, storage facilities, and upper level office space and parking. The new dam will replace the current Tainter Gate located a few hundred feet upstream. Completion was scheduled for April 1986 (SARA 1985:15-16). 


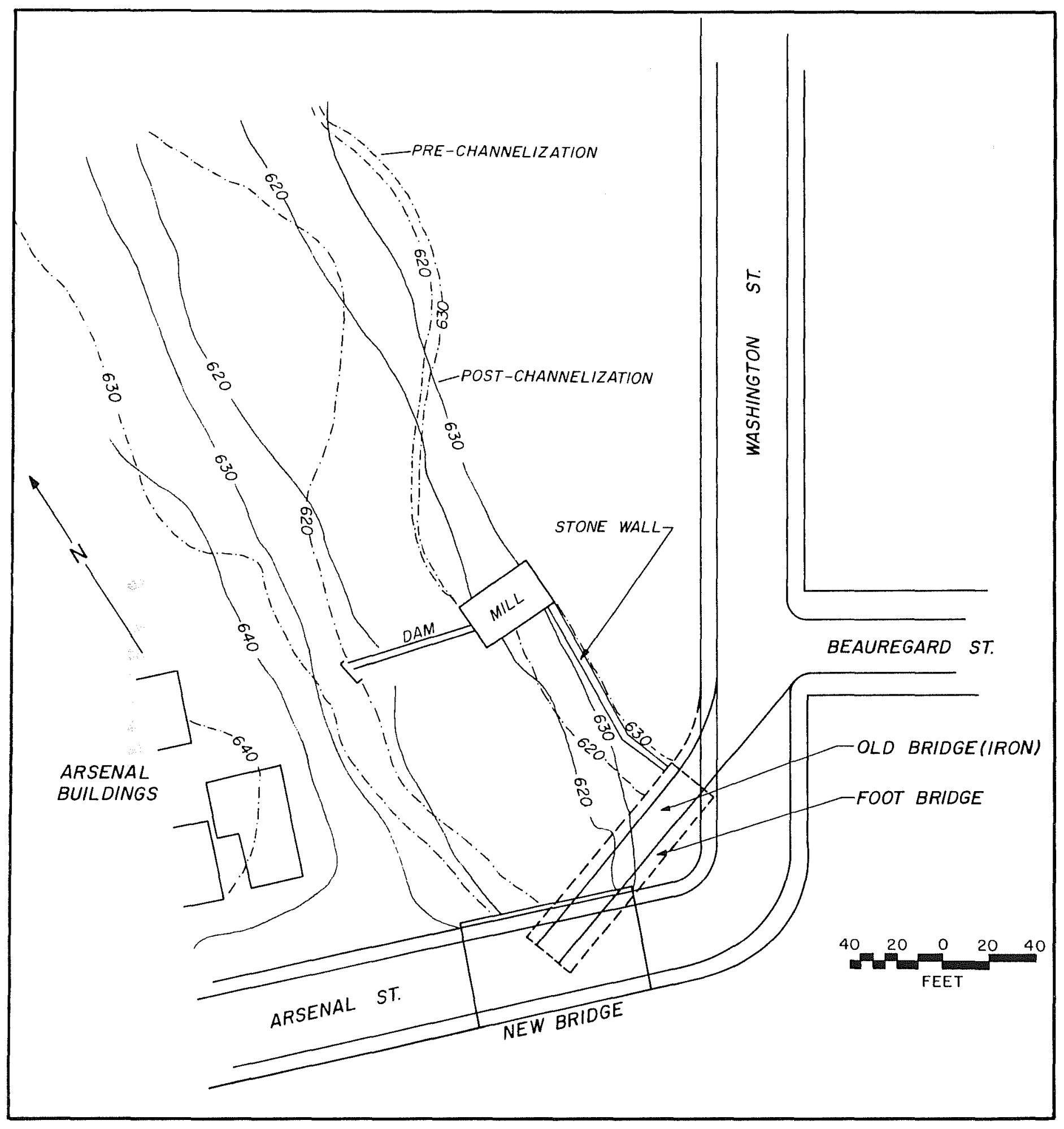

Figure 2. Composite Map of Mill Site, Showing Pre-Channelization and PostChannelization Contours. 


\section{MILLS AND MILLING IN 19TH-CENTURY TEXAS}

Long before the first Europeans arrived in Texas, the native Americans were using grinding implements to prepare the fruits and seeds of wild plants. Deep mortar holes in the bedrock, flat stones with smoothed concavities, and hand-sized quartzite grinding stones found on and near prehistoric sites demonstrate an early knowledge of grinding techniques (Turner and Hester 1985:249). The Spanish settlers who came to Texas in the early 18th century brought metates and manos of volcanic stone to prepare corn for their traditional recipes. Late in the Spanish colonial period a few small grist mills were built using waterpower.

The Ang10-Americans who immigrated to Texas in the early 19th century grew corn which they ground with much effort on small hand-powered steel mills (Jackson 1971:23-27), dreaming of the day when they could have wheat flour for real biscuits and white bread such as they had enjoyed "back home." They were soon joined by Europeans who also had a background of using wheat flour, and it was not long before grist mills appeared on many streams and rivers. At first they ground corn, a welcome relief to families who had been grinding by hand. Very soon fields of wheat were planted and harvested, and local milling technology was expanded to handle both corn and wheat in the same mi11. As the immigrant population expanded, so did the demand for white flour. By mid-century enterprising millers were importing wheat to keep up with the demand, and custom mills that had been grinding for farmers for a fixed share or "toll" of the grain to be ground became merchant millers, selling flour and meal to local residents (Kuhlmann 1973:xiii). Guenther's Upper Mi11, about which this report is written, was a part of this evolution of milling as it took place in the last half of the 19 th century in San Antonio.

In order to interpret what was found at the site of Guenther's Upper Mi11, it is necessary to understand how 19th-century mills were built and how they operated. Most of the information in this section is taken from either of two sources. The first is a book entitled The Young Mill-Wright and Miller's Guide published in 1832 by 07 iver Evans. We are fortunate to have an early edition of this excellent, detailed handbook available for researchers in the Ernst Schuchard collection of the Daughters of the Republic of Texas Research Library at the Alamo. A reprint (Evans 1972) of the 13th edition with additions and corrections by Thomas $P$. Jones of the Franklin Institute in Philadelphia can be found in the John Peace Library at The University of Texas at San Antonio. Another good source of milling background is a fine report by Gregory Jeane (1979) of the Department of Geography at Auburn University on his work in documenting McCosh's Mill in Alabama. A copy of this report is in the files of the Center laboratory.

\section{THE WATERPOWER TO DRIVE THE MILL}

The first and probably the most important consideration in construction of a water mill was the location and construction of the milldam that controlled the flow of water to the mill. Construction of the dam must be carefully thought out. Evans (1832:197-198) listed six considerations in building milidams: 
1. Construct them so, that the water, tumbling over them, cannot undermine their foundations at the lower side.

2. So that heavy logs, large pieces of ice, etc. floating down, cannot catch against any part of them, but slide easily over.

3. So that pressure or force of the current of the water will press their parts more firmly together.

4. Give them a sufficient tumbling space to vent all the water in time of freshets.

5. Make the abutments so high, that the water will not overflow them in time of freshets.

6. Let the dam and mill be a sufficient distance apart, so that the dam will not raise the water on the mill, in time of high floods.

Evans also remarked, as a footnote to the last point,

I have, in many instances, seen the mill set so close to the dam, that the pierhead or forebay was in the breast, so that in the case of a leak or breach about the forebay or mill, there was no chance of shutting off the water or conveying it another way; but al1 must be left to its fate. The mill is frequently broken down, and carried away; even the mill stones are carried a considerable distance down the stream, and sometimes buried under the sand, and never found.

Obviously such a catastrophe must be avoided if at all possible. The dam must have a flood control gate to allow the water to bypass the mill at the time of a flood. There also must be a head gate which could be raised to allow the water into the millrace, or, as in the Guenther's Upper Mill, directly into the mill. The millrace was a canal or flume through which the water flowed to reach the mill. Its length and design depended on the distance from the dam to the mill and their comparative elevations. Trash racks at either end of the millrace served to catch debris and keep it from fouting the wheet or turbine.

\section{CONSTRUCTION OF THE MILL}

Water flowed through the millrace to the forebay, an enclosure between the last trash rack and the wheel pit. The forebay delivered the water to the wheel in various ways depending upon the design of the whee?.

The wheel pit must be constructed so as to make maximum use of the head and fall of the water, and must be sufficiently wide so that there is no loss of power due to the water reacting upon the wheel. There must also be a uniform depth out into the tailrace which carried the water away from the wheel pit, to allow the water to discharge freely, again, to avoid loss of power. 
The choice of the type of wheel depended, among other things, upon the height of the water source in relationship to the mill and on the volume of water that could be delivered (Fig. 3). A wheel could be overshot, meaning the water was carried over the top to fall onto the far side of the wheel: For a breast or breast shot wheel, the water hit at about the center and flowed beneath the wheel. An undershot wheel was turned by the water flowing under it, hitting the wheel at a tangent near the bottom of its circumference. Evans (1832:278) stated that an undershot wheel, 18 feet in diameter with three feet total head and fall (the approximate description of Guenther's Upper Mi11), should be two feet wide for every foot of diameter of the millstones, that is eight feet for a four-foot stone or ten feet for a fivefoot stone. The shaft on which it turns should be at least 26 inches in diameter.

Mill wheels were built on the site according to the specifications of the millwright, as was most of the machinery for operating the mill, which was made of wood in the early days. All the shafts and gearing were made by local carpenters at the millwright's direction. Evans included careful descriptions of how to make various wheels, racks, gears, shafts, and other appurtenances necessary to run the mill. He also cautioned that all mill work is subject to constant vibration, or "tremor" that not only weakens the structure but can cause loss of power. "It ought, therefore, to be not only sufficiently strong and stiff, but sufficiently heavy, to give solidity and steadiness" (Evans 1832:391).

Horizontal water wheels, or turbines, enclosed in a metal casing, began to replace the vertical wooden water wheel about 1850 in Texas (Wimberley 1965:11). The insertion of a turbine into a traditional water mill entailed construction of a heavy wooden frame to support the turbine, using eightand/or ten-inch square timbers (Jeane 1979:46), but once installed little maintenance was needed (Reynolds 1970:66).

Evans (1832:199-200) also gave advice on the construction of the mill building itself. On building mill walls, he specified that the lower, foundation walls be of stone, stating important principles to be followed:

1. To lay the foundations with large good stones, so deep as to be out of danger of being undermined, in case of any accident of the water breaking through at the mill.

2. Set the center of gravity, or weight of the wall, on the centre of its foundation.

3. Use good mortar, and it will, in time, petrify and become as hard as stone.

Then, in a footnote, he (Evans 1832:200) remarks:

Good mortar, that is made of pure and well-burnt limestone, properly made up with sharp clean sand, free from any sort of earth, loam, or mud, will, in considerable time, actually petrify and as it were, turn to the consistency of stone. It is better to put too much sand into your mortar than too little. Workmen choose 


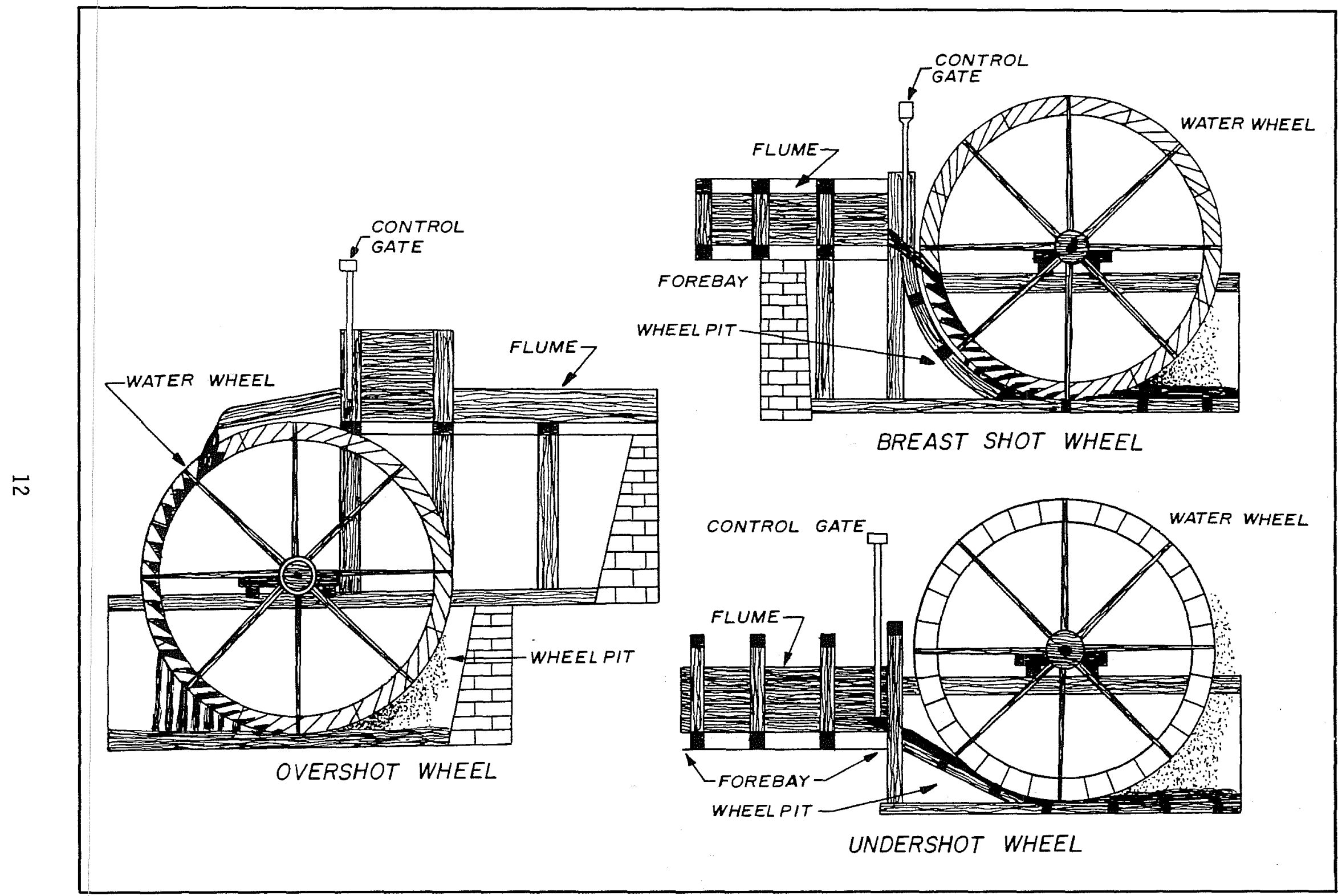

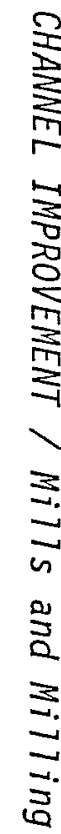

Figure 3. Various Types of Water Wheel Installation. 
their mortar rich, because it works pleasanter; but rich mortar will not stand the weather so well, nor grow so hard, as poor mortar will do. If it was all lime, it would have little more strength than clay.

\section{GRINDING}

The best way to understand the grinding process and the various steps and machines involved is to follow a sack of grain as it arrives at the mill. In order to set the scene, first picture a tall, frame structure (a1though some mi17s in Texas were built of stone, most were of frame construction) perched on the bank of a stream. Tied in front are a number of farm wagons and horses, their drivers gathered in the shade in front of the mil1 as they wait for their grain to be ground. You pull up your wagon and join the group.

When your turn arrives, the miller comes to the door and beckons to you to bring your sack inside. The volume of sound assaults your senses as you struggle to hoist the heavy sack into the mill door--the sound of water falling below, the thunder and creak of the gears, and the crunching of the stones make it necessary to yell to be heard. The whole building trembles with the vibration of the machinery. The odors of corn and other grains and freshly ground, warm meal fill the air. There is a fine dust in the air and over everything in the mill.

Your grain is weighed, and the miller measures out his toll, a set fraction of the total amount to be ground. This is his charge for grinding, and the miller sells either the grain or the resulting flour or meal in order to maintain the mill in operation and feed and clothe his family. The grain is next cleaned by sifting to remove dirt and other extraneous materials, then carried up to the top floor of the mill to begin the grinding process. In the older mills the sack of grain was hoisted by a rope and pulley attached to the power chain of the mill (Reynolds 1970:50), then hauled by hand to the bin. Later, a series of vertical and horizontal conveyors carried the grain throughout the mi11 (Evans 1832:P1ate VIII), saving the miller a great deal of 1 abor.

Once the grain is in the bin, the power of gravity takes over (Fig. 4) as the grain drops into a wooden hopper set over the millstones on the next floor. The hopper allows a controlled stream of grain to fall into the "eye" in the center of the upper or "runner" stone, to be ground between it and the lower or "bedder" stone. A wooden casing surrounds the stones, and brushes or tabs attached to the runner sweep the ground material around to a spout where it falls into a bin (Storck and Teague 1953:102).

If the grain was corn, at this point the meal may be returned to your sack ready to take to the wagon. If it was wheat, there is another process yet to do. After it is ground, wheat flour goes to a bolting machine where it is sifted to separate out various qualities of flour--bran, shorts, middlings, and white flour--each with its particular household uses. These different grades are then sacked and are ready to take home. 


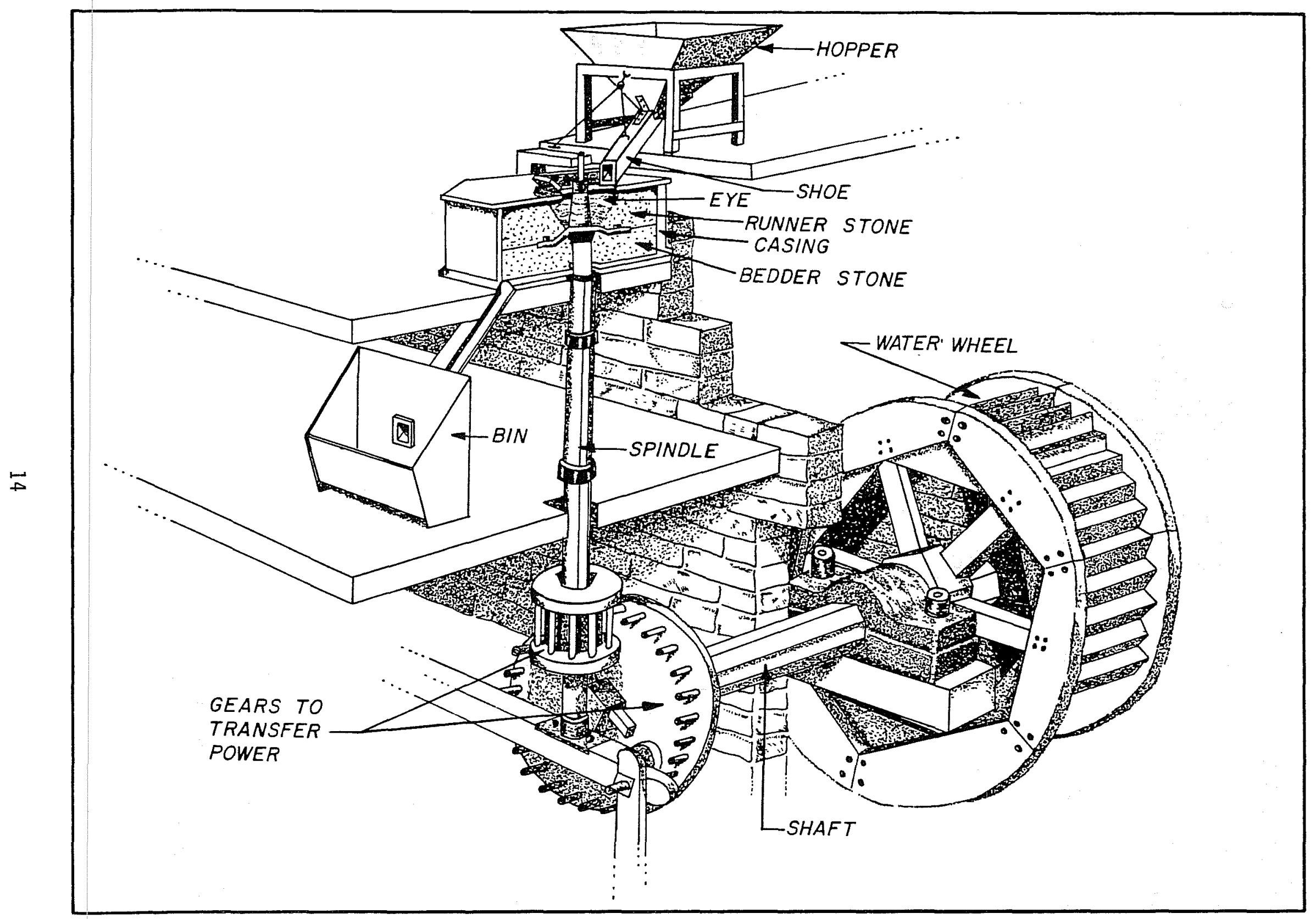

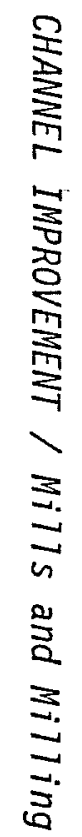

Figure 4. Diagram of Mill Operation. 


\section{THE MILLSTONES}

At the heart of the mill were the millstones. Since they had to withstand years of heavy use and continual resharpening, it was necessary that they be made of exceptionally durable stone. While a good millwright could design and build everything else in his mill, the stones were usually imported from Europe, at great labor and expense. The finest stones were French burr (or buhr) stones composed of blocks of a particular type of quartz quarried principally in the Marne Valley of northern France (Howell 1982). The pieces were shaped and matched with great care, set in cement, and bound with iron hoops (Reynolds 1970:44).

The working surfaces of the stones required careful preparation by skilled stone dressers. Soft millstones would have to be sharpened or dressed as often as every three weeks. Burr stones required dressing as 1ittle as once or twice a year (Jeane 1979:75). Since this process required that the stones be out of service for the time it took to hoist the runner, dress both stones laboriously with hand picks, then reinstall and carefully balance the runner stone, it was worth importing French stones.

The miller who continued to grind with dull millstones was defeating the purpose of grinding, which, according to Evans (1832:245) was to,

reduce it to such a degree of fineness, as is found by experience to make the best bread, and to put it in such a state, that the flour may be most effectually separated from the bran or skin of the grain, by means of sifting and bolting.

In order to grind properly, the stones must first cut the grain into several pieces, then grind these to a required degree of fineness, scraping the bran or skin cleanly from the meal. To accomplish these tasks, the grinding surfaces were commonly marked out into a number of equal sectors or "harps" by lines drawn tangent to the eye in the center of the stone. Harps were divided into alternating "lands" (flat areas) and "furrows" cut one-half to three-quarters of an inch deep. A system of fine parallel grooves called "stitching" or "cracking" was then added to each 1and. When the stones were installed face to face, the furrows crossed and cut with a scissorlike action (Reynolds 1970:44). The grain fragments were then crushed and ground on the lands, the meal or flour falling into the furrows and working toward the outer edge of the stones where it was swept into a bin, as described earlier.

Installation of the runner stone was a delicate job, requiring exact balance in order to maintain the proper clearance between the stones. First, the bearings of the spindle upon which the runner was placed had to be adjusted to make sure the stone would be absolutely horizontal. Then the stone was put in place and balanced by pouring melted lead into cavities cut into the back, or top, of the stone. These careful adjustments were essential to insure that the stones did not touch while in motion, or the resulting sparks could set fire to the mill. Friction from improperly balanced millstones could also produce rapid wear, making more frequent dressing necessary (Reynolds 1970:47). Toward the end of the 19th century, millstones were being replaced by rollers for milling wheat. These were made of casehardened iron, chitled in the mould (Amos 1912:136), and they did a more 
efficient job than the stones. However, at least one pair of millstones was generally retained for grinding corn (Howel1 1982).

\section{SOCIAL ASPECTS OF THE MILL}

On certain days and in particular seasons it was not at a71 unusual to see a line of horses and wagons drawn up outside the local mill waiting their turn for grinding. At such times there was much conversation among the waiting farmers--talk of politics, weather, local news. The location of the millpond behind the dam was an attractive place for fishing and swimming, and for church and school picnics. In some mills, one floor was occasionally cleared off to be used for dancing (Jeane 1979:86-87). Thus, the mill became a social center for the community, a place to meet and talk with neighbors and to hold community events.

A boy's first impressions of the mill were obtained when he went along with his father or older brother on the regular trip to have the grain ground. The day when he was entrusted with the responsibility of carrying the family meal sack to the mill was an important milestone in a young man's life.

A central Texas miller (Wimberley 1965:18) has left us this description of a family's preparation for the trip to the mill:

Preparing corn for the mill was, in the old days, a usual family chore. After the ears of corn had been brought from the field they shucked and nubbed (the faulty and insect damaged kernels were removed from the end of the cobs). The remainder of the grain was shelled from the cobs and winnowed. This was usually done by pouring the grain from one vessel to another, allowing the wind to carry away the chaff. It was then sacked and ready for milling. Filled with shelled corn at home and returned filled with meal, the family meal sack made regular round-trips to the mill. The old seamless meal sack was made of a coarse woven cotton cloth, white with red and blue pin-stripes down either side. It held two bushels of shelled corn when filled, and with a single bushel halved to the ends, it rode well when thrown across a horse's back.

The trip to the mill was often a long one, sometimes involving an overnight stay before the return trip home. On such occasions the entire family might go along. They would attend to numerous errands in town at the same time, then camp out at the mill overnight before going home the next day (Jeane 1979:142, 166).

\section{THE MILLER}

It was traditional that the miller learned his craft from his father. Working around the mill from his youth, he learned the complicated engineering necessary to keep the mill running. He became accustomed to handling heavy objects, from sacks of meal to millstones. Physical strength and ingenuity were two requirements for the job, which tended to make the miller more mentally alert and more independent than others (Reynolds 
1970:16). He was accomplished in many skills--carpentry, architecture, engineering, basic mechanics, and hydraulics. In order to understand the workings of the mill, he had to master the basic mechanical principles of gearing, the lever, the inclined plane, the wedge, the screw, the pulley, and the crank (Zimiles and Zimiles 1973:6). Therefore, the miller often was a father figure in his community (Jeane 1979:156), respected for his skills and his ability to make judgements and decisions.

A more tragic aspect was the "miller's cough," a complaint caused by daily inhaling the dust in the mill (Reynolds 1970:16). Nineteenth-century medicine generally called this ailment "asthma," and knew relatively little about its treatment or prevention. C. H. Guenther may well have suffered from this ailment, at least in the later years of his life. In a letter written in 1879 (Hurst n.d.:Letter 46), he tells of his disability,

I have to put up with a lot on account of this asthma. . . I am now unable to work very much, but if I can just stay in the mill for 3 hours everyday, that suffices and I can supervise everything.

\section{PREVIOUS ARCHAEOLOGY AT TEXAS MILLS}

To our knowledge only three other extensive archaeological investigations have been carried out at grist mill sites in central Texas. At least these are the only ones for which published reports could be found.

In 1963-1964, the Texas Archeological Society conducted weekend archaeology at the site of Anderson's Mill about 17 miles northwest of Austin in Travis County (Durrenberger 1965). The mill was built in the early 1860s and abandoned in the 1920s. Little remained of the mill, and there was relatively litle archaeological investigation of the mill structure during the project. The report concentrated on the artifacts recovered.

A more intensive investigation was carried out by a Texas Archeological Society Field School and Texas Parks and Wildlife Department personnel at the Thomas F. Mckinney homestead and mill on Onion Creek south of Austin in 1981 (McEachern and Ralph 1981). Altogether 69 units were excavated at various locations on the mill site, and the wheel pit was excavated to record the turbine at the bottom. No evidence of the mill remains except below surface wall bases, the forebay and wheel pit stonework, and the millrace. Iron supports for a wooden dam still remain in holes drilled into the bedrock in the streambed upstream from the mi11. Study of this report was helpful in understanding the layout of Guenther's mi11s.

Between 1975 and 1980, the Texas Parks and Wildlife Department personnel conducted research and excavations at the Landmark Inn State Historic Site in Castroville (Parsons and Burnett 1984). Included in the investigations was a considerable amount of work at the dam, mil7race, and mil1 site of the Courand Mi11, built in 1854 on the historic site. Detailed recording was done of the remaining building and various pieces of equipment still present. Since this mill was contemporary with Guenther's operations, there are many similarities in the developmental changes both mills underwent, from water whee? to turbine to steam power, and from custom grinding to a commercial 
operation. The Courand Mill differed in that the waterpower was also used to run a cotton gin and a lumber mill, whereas the Guenther Mill concentrated solely on grain milling.

A search for additional mills investigated was conducted in the records for central Texas counties at the Texas Archeological Research Laboratory in Austin. The records of counties searched were Bandera, Bexar, Blanco, Comal, Gillespie, Guadalupe, Hays, Kendall, Kerr, Medina, and Wilson. Only three additional water mills have been recorded and received state numbers.

The William A. Thompson Dam and Millrace site (41 HY 164) on the San Marcos River near San Marcos was recorded by U. Kleinschmidt. The mill was built in 1850. Only the dam, pond, sluiceway, and water wheel foundation are still intact (Howard 1985:2). This site has been nominated to the National Register of Historic Places.

A site survey form (Hall 1977) records a historic mill site (41 KR 130) on a terrace above the Guadalupe River in Kerrville. Grant Hall reported at the time that only the cut limestone walls of the mill foundation still remained in the river bank.

In July $1984, C$. K. Chandler recorded the ruins of the Guadalupe Mills (41 KE 90), originally a grist mill and sawmill on the Guadalupe River near Sisterdale in Kendall County. Stone walls still present on that site represent the lower portions of the mill foundation and wheel pit.

A. T. Jackson (1971) did a tremendous amount of research into the location and description of Texas water mills in preparation for his book, Mills of Yesteryear. He found evidence for over $175 \mathrm{mills}$ in Texas through written records and eyewitness accounts (Jackson n.d.:File 3G115). Judging from the few mill sites recorded, it seems probable that remains of most of these mills are still present in some form in the ground. A concerted effort should be made to locate and record these sites before they are eliminated by channelization or development. 


\section{HISTORY OF GUENTHER'S UPPER MILL}

In order to understand the history of an archaeological site, it is necessary to learn something about the people who have owned the land and how the ownership has changed hands over the years. It is also helpful to know how the various owners used and altered the site for their individual purposes. In order to present a11 of this information in a straightforward manner, we have chosen to divide this section into two parts. The first part will deal specifically with the ownership of the property on which the mill was built and the next lot to the north, which now also belongs to the City of San Antonio. The second part will describe the history and development of Guenther's Upper Mill and later uses of the property after the mill ceased to operate.

\section{OWNERSHIP HISTORY}

On April 11, 1793, the King of Spain granted one suerte of 1 and in the Lower Labor of Mission San Antonio de Valero to Vicente Amador, Alcalde of San Antonio (Spanish Archives Vol. 2:60). Vicente Ferrer Enriques de Amador had come to San Antonio from CeTaya in 1756 (Chabot 1937:194).

Amador sold the suerte in 1813 to Senior Alderman Manuel Barrera for $\$ 300$ (Spanish Archives Vol. 2:225). Barrera was a Spanish merchant who had come to San Antonio from Coahuila (Chabot 1937:99).

In 1832, John McMullen bought the suerte from Barrera for $\$ 160$ (BCDR Vol. C$1: 136)$. At that time McMullen was involved in an empressario contract with James McGloin to introduce 200 families into south Texas (Webb Vol. II 1952:122). In 1844, McMullen sold out his part of the contract to his partner, and sold the suerte in question to Thomas $J$. Devine for $\$ 600$ (BCDR Vol. B-2:306). The money he obtained from these transactions apparently went into the new mercantile business he was starting (Webb Vol. II 1952:122).

By the time Thomas J. Devine came to San Antonio in 1842, he had become a practicing attorney and had married Helen Ann Elder of La Grange. In quick succession Devine became city attorney, then district attorney, and then was elected district judge (Chabot 1937:322-324). In 1853, Devine sold to his sister-in-law, Caroline Catherine Elder, the "two upper tables" of his suerte of 1 and for $\$ 1600$ (BCDR Vo1. I-1:254).

By June 1859, Catherine and her husband, Newton A. Mitche11, had subdivided their portion of the suerte for development (Fig. 5). Apparently the area had become a part of San Antonio by this time, since the plat was drawn up by G. Friesleben, city surveyor (Burkholder 1973:9). The Mitchells sold Lots 7, 8,9 , and 10 of their subdivision to Thomas H. Stribling, a prominent locial lawyer, for $\$ 600$ (BCDR Vol. R-1:550). Stribling and his wife then built a sma11, one-story stone house on their newly acquired property. In the same year, Newton Mitche11 and his wife built their home at 209 Washington Street, on a section of land which they had retained. These appear to have been the first two houses built in the immediate area. 


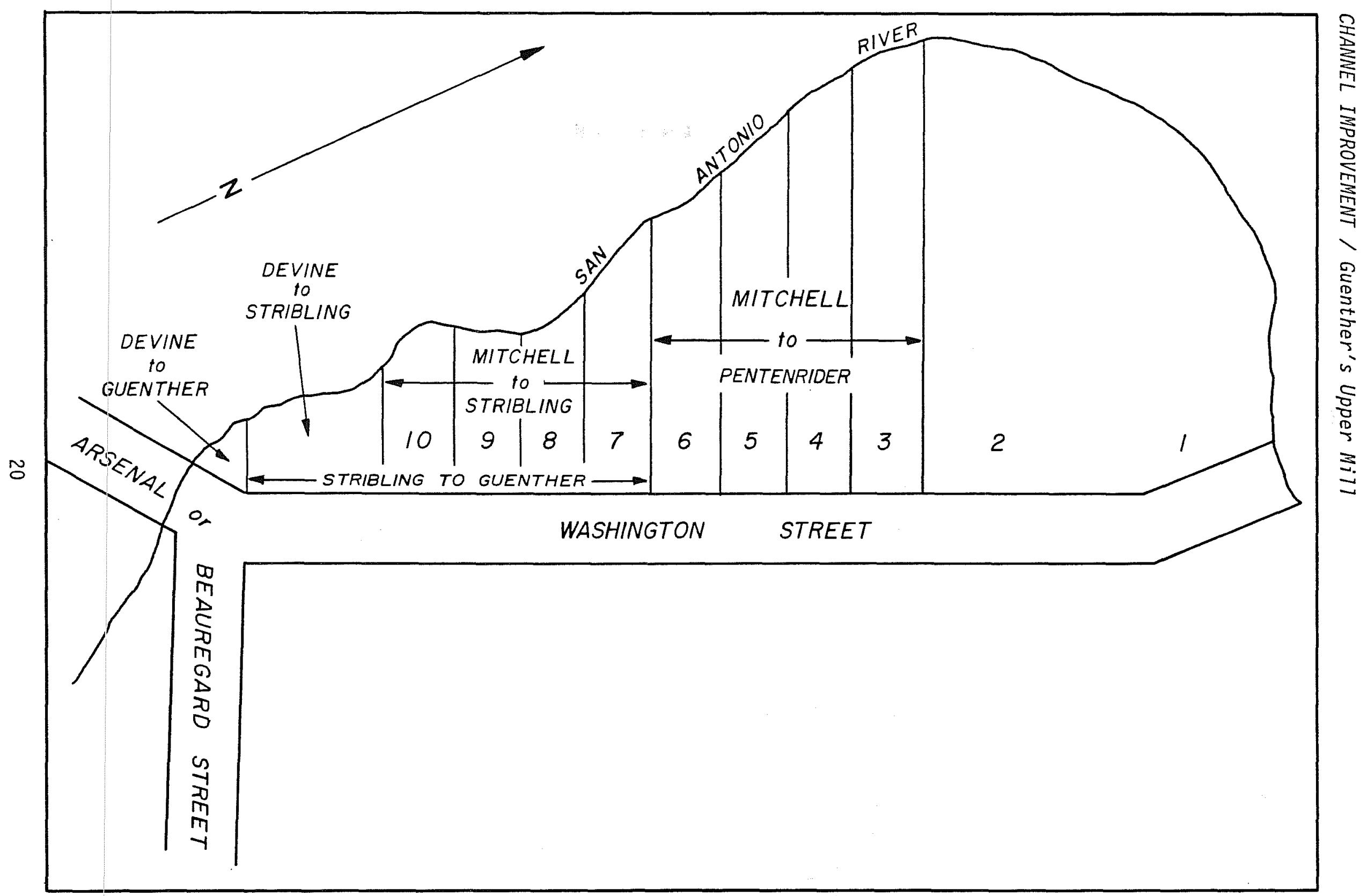

Figure 5. Ownership History of Mill Area. Numbers represent lots. Not drawn to scale. 
Rising rapidly in the political and social life of San Antonio, the Striblings advertised their small homestead for sale six years later in the San Antonio Herald (1865):

\author{
House for Sale
}

A beautiful house fronting 100 yards on river, opposite the Arsenal embracing the falls. It has fine water power, suitable for a mill seat. A good stone house on the place. A garden and plenty of shade.

Judge Stribling

Carl H. Guenther availed himself of this opportunity to acquire another mill site by purchasing the Stribling property for $\$ 4250$ in 0ctober of the same year (BCDR Vol. T-2:65). Then in December he purchased the small triangle of Tand between his southern boundary and Arsenal Street (BCDR Vo1. U-1:179). Meanwhile Guenther, an astute businessman, had sold the Stribling House and all the property to the north of the mill site which he did not intend to use to Erhard Pentenrider for $\$ 3500$ (BCDR Vol. U-2:282). In 1875, Pentenrider sold the Stribling House and property to Hermann Barbeck for $\$ 10,000$ (BCDR Vol. 4:183). The property stayed in the Barbeck family until 1926, when it was sold to the City of San Antonio, and the house was demolished.

Guenther built his new mill on the property to the south, as planned. The mill remained in operation until about 1900, after which the property was leased to a succession of other business firms. It was sold to the City of San Antonio in 1926 in order to allow the elimination of the dam for a flood control project. In the process, all the buildings remaining on the Guenther property were demolished, including the mill (San Antonio Express 1926).

The 7 and on which the Stribling House and mill had stood remained in City ownership until 1940, when it was sold to Louis and Virginia Theis. They in turn sold it almost immediately to Eli and Aileen Goldstein (BCDR Vol. 1743:360 and Vol. 1763:532), who built a one-story house near the old mill site.

\title{
THE GUENTHER MILLS
}

Carl Hilmar Guenther, the son of a prosperous merchant of Weissenfels, Saxony, left his home and arrived in New York on June 30, 1848. In Germany he had been trained as a millwright and had been accepted as a master miller by the millwrights guild of Sachsen near Weissenfels in 1844 (Beckmann $1951: 2)$.

Guenther supported himself with the skills and talents of his trade, travelling through the north, the midwest, and eventually down the Mississippi to Louisiana. He took a boat from New Orleans to Indianola, then walked from there to San Antonio. In a letter dated January 7, 1851, from San Antonio, he wrote to his father in Germany, 
I wrote from New Orleans that soon I might write home for money. That time has now arrived, for I want to buy land along some river near here as soon as possible and there build a mill (Hurst n.d.: Letter 10).

In mid-March 1851, he purchased 150 acres near Fredericksburg on Live Oak Creek, with a good location for a mill (Hurst n.d.:Letter 11).

During the next several months the building of the dam and mill progressed. The millstones arrived from France and soon he could write home (Hurst n.d.:Letter 15),

With pleasure I can now report that my mill is running. . . the machinery runs 7 ike a clock. Up to now I have not needed a milling engineer, for everything was built by carpenters and cabinet makers who worked by my drawings.

As his business prospered, Guenther invested his profits in the expansion of the mi17. In 1855, he married Dorethea Pape, the daughter of his neighbor, Friedrich Pape. The newlyweds built a house near the mi11, where their first two children were born, Fritz in 1857 and Arthur in 1859.

In a letter dated August 22, 1859, to his mother, Guenther wrote,

Everything's fine with us. Everybody is well and contented. My business is middling. But soon I will have strong competition. The merchants in Fredericksburg are building a mill to run by steam. This will hurt my mill during these first years. I had already made enquiries about buying a steam engine and mentioned it in public to interest farmers in planting more wheat for next year. Immediately these merchants who had pledged themselves not to build a mill now agreed to combine and together buy a steam mill and the building has begun.

I wi1l not compete with this steam mi11, as I figure there is only enough business here for one such mill. So I have decided to travel to San Antonio in two days and find a better location for my steam and water powered mi1l. San Antonio has now 10,000 inhabitants, and only one very meager water mill (Hurst n.d.:Letter 33).

On August 26, 1859, Guenther bought a tract of 1 and for $\$ 2500$ on a bend of the San Antonio River, in an undeveloped area just south of town (Hurst n.d.:Letter 35). Depending totally on the support provided by the Live Oak Creek mill, the family settled in San Antonio, and the new mill was built (Hurst n.d.:Letter 36). By May of the following year, the San Antonio mill was running. Probably part of what had drawn Guenther to San Antonio was the period of prosperity the town had experienced in the early 1850s after statehood was achieved. The area enjoyed good crops and an influx of new settlers (Wangler 1974:11). The Anglo-Americans arriving from the southern United States were primarily stockmen who grew enough corn to feed their families. The Europeans from Alsace and Germany, however, were primarily farmers and planted wheat as well. Between the two groups, there was plenty 
of custom grinding at first, as long as the rains came in the proper season. In times of drought, the miller suffered along with the farmers.

In mid-January 1861, Guenther wrote his mother,

The Live 0ak Mill was sold to my father-in-law for $\$ 4,000.00$. . . My business is doing right well and we now feel settled again and have the feeling of home once more (Hurst n.d.:Letter 38).

Guenther's milling business prospered, serving farmers throughout the area and from as far away as Castroville (Beckmann 1951:6) and Pleasanton. John M. Doak (Lauderdale and Doak 1936:2), who spent his boyhood in Pleasanton, described how his family "would take the corn to the old Guenther Mill in San Antonio. We would pay Mr. Guenther for grinding and then we would buy a little flour. After that we would have flour bread occasionally."

Guenther continued to operate throughout the Civil War and expanded the mill further, prudently investing his profits in improvements and new machinery. It was probably the undependable south Texas weather, along with his natural ambition, that persuaded $C$. H. Guenther to expand into a merchant milling operation. It was not long before he was importing ox cart loads of wheat (Beckmann 1951:6) to make flour for sale to the general public.

By 1865, the mill was operating at full capacity, yet there was need for more milling services for the growing town. In order to obtain adequate power, it would be necessary to find an additional mill site (Beckmann 1951:7). It was at this time that Judge Stribling decided to sell his property, which included the next waterfall upstream from Guenther's mill. Guenther bought the property, as described previously, and began planning his New or Upper $\mathrm{Mi17}$. As he gathered his resources, Guenther planned methodically the best way to lay out the mill so as to get the best use of the site. Part of his careful planning is reflected in the deed drawn up when he sold the unneeded Tand to Pentenrider (BCDR Vol. U-2:282):

\begin{abstract}
- . as there is a fall in the River on that part of the land purchased of Stribling and wife which I have not conveyed to Pentenrider and which I intend to use for the purpose of running a mi11, I reserve the right to raise the water six inches above its present level by filling up the fissures or open places in the rocks which form the natural dam so as to make the whole dam on a level with the highest points of said rocks.
\end{abstract}

The relatively small size and the contours of the property limited the choices for placement of the mill in relation to its dam. Guenther laid out his new mill at the east end of the dam, so that the water could be either taken directly into the forebay by opening the head gate, or diverted downstream over a spillway in the dam when the wheel was not in operation. To judge by later photographs, he built the dam in the manner he had described in the Pentenrider deed, raising the water behind it only slightly above the original level. We have no records on the construction of the mill, but would suppose that Guenther's training as a millwright plus his experience gave him the self-confidence to design the new mill without the aid of a milling engineer, as he had done at Live oak creek. There were by 
this time experienced carpenters and cabinetmakers in San Antonio who could build the mill and fabricate the needed equipment from Guenther!s plans and specifications.

The mill went into operation in 1868 with an undershot wheel. (Gould 1882:85). The mill foundations were of cut limestone set solidly in lime mortar. The stone walls extended up to the level of the first or main floor of the structure. Above this was a one and one-half story frame building that contained the milling machinery (Fig. 6). Before long, a bran room was added across the north wall of the mill, and a warehouse/office building was constructed next to Washington Street (Fig. 7).

The 1870s started well for the Guenther family. There were now seven children in the family, four boys and three girls (United States Department of the Interior, Office of the Census 1870). The two eldest sons were apparently following in their father's footsteps in the traditional manner. In 1879, the firm became $\mathrm{C}$. H: Guenther \&. Sons, each of the boys assuming an official place in the business although they were both in their early twenties.

Guenther's mills had become well-known as places for recreation as well as business. Near the Upper Mill was a favorite swimming hole for the neighborhood boys (James 1938:43). Numerous picnics were held on the banks of the river at the mills, sometimes with singing and fireworks (Chabot 1937:378).

Whereas there had been only a few houses in the vicinity when the Upper Mill was built, the 1870s saw the beginning of development in what is today called the King William area. The land between the river and South Alamo Street north of the Lower Mill was about to become a fashionable place to live (Burkholder 1973:10). Directly across the river from the Upper Mil1, the United States Arsenal was building additional stone buildings and landscaping its grounds (Fox 1986:4).

Despite a severe drought from 1878 to 1879 (Farris 1985:xiv), Guenther's mills continued to prosper. This was partly due to the arrival of the first railroad in San Antonio in 1876, which allowed bulk shipments of wheat and flour at an economical rate (Beckmann 1951:7). This expanded both the area from which grain could be obtained and the markets to which flour and other milling products could be sent. A new mill was built at the Lower Mill strictly to produce flour on a commercial basis. The flour was handled and distributed from the Upper Mill, as it was more convenient to San Antonio customers (San Antonio Herald, May 29, 1878, quoted in Everett 1975:134).

An 1882 account (Gould 1882:85) described the Upper Mill as being powered by a 30-horsepower undershot water wheel which operated three pair of stones. The capacity of the mill was estimated to be 20 barrels of flour and 250 bushels of corn in 24 hours. However, in a letter written January 29, 1883 (Hurst n.d.: Letter 48), Guenther reports,

During the last two years, our mills have not earned anything. We increased the capacity considerably, bought the newest machinery, ran everything on a strictly business basis, but nothing helped, because for 2 years West Texas has had no wheat crop. We had to 
CHANNEL IMPROVEMENT / Guenther's Upper Mill

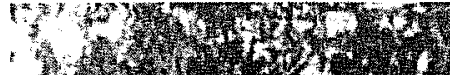
1.6.6.

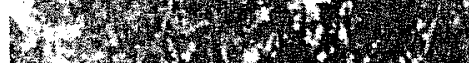
(1)

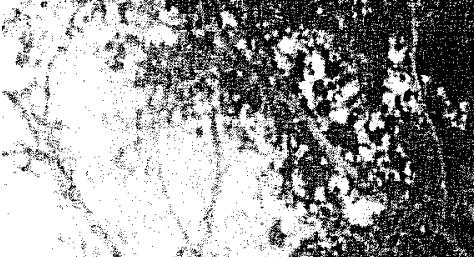
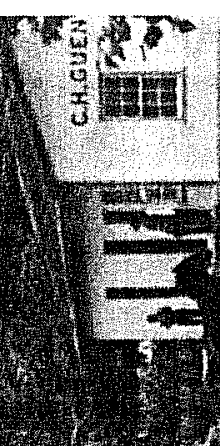

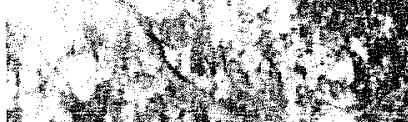

W. W W W

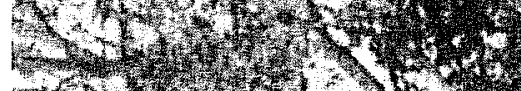

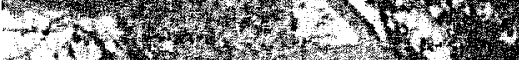

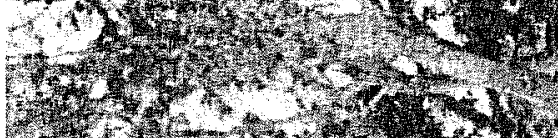
(5)

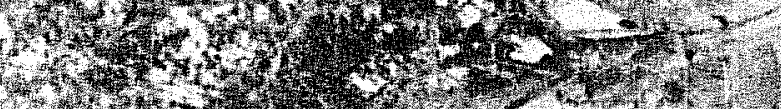

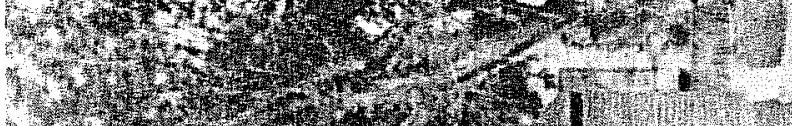

1. H.t. H.t. (3)
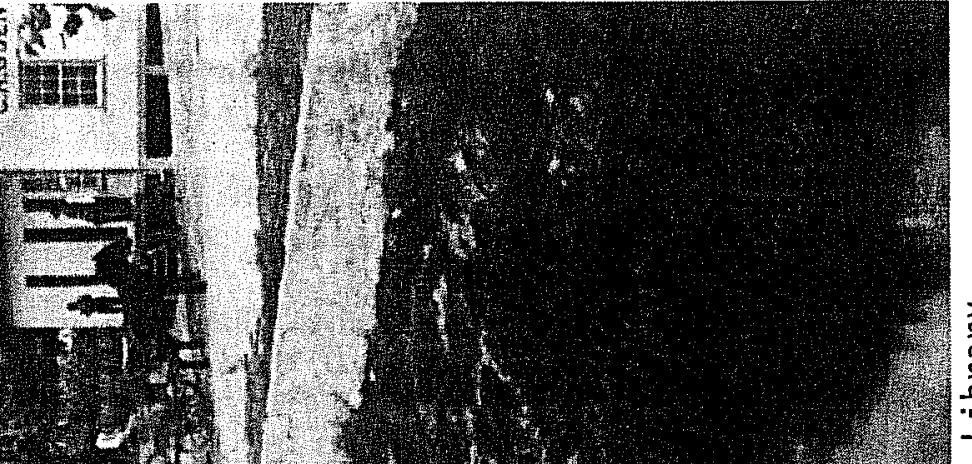

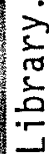

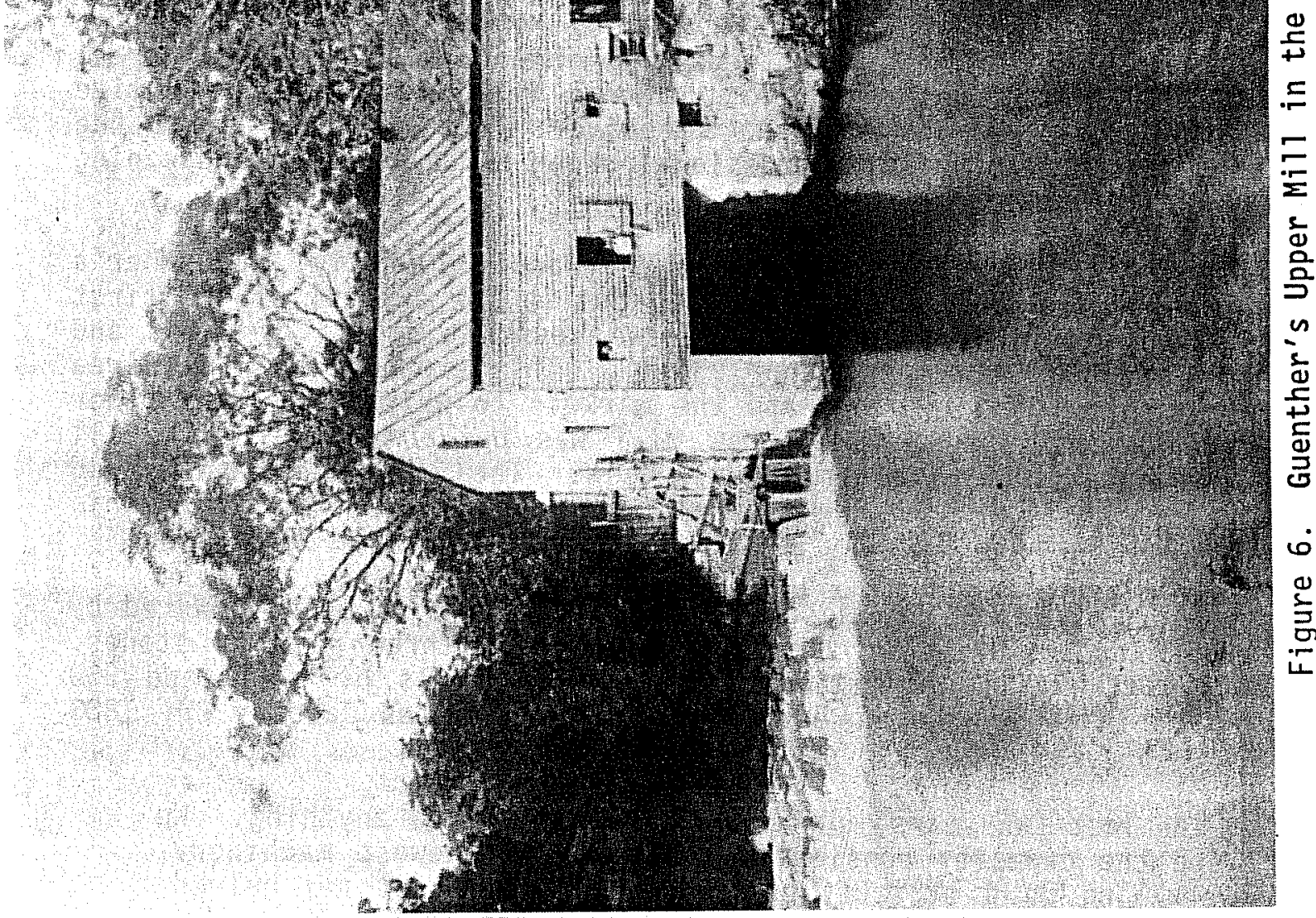




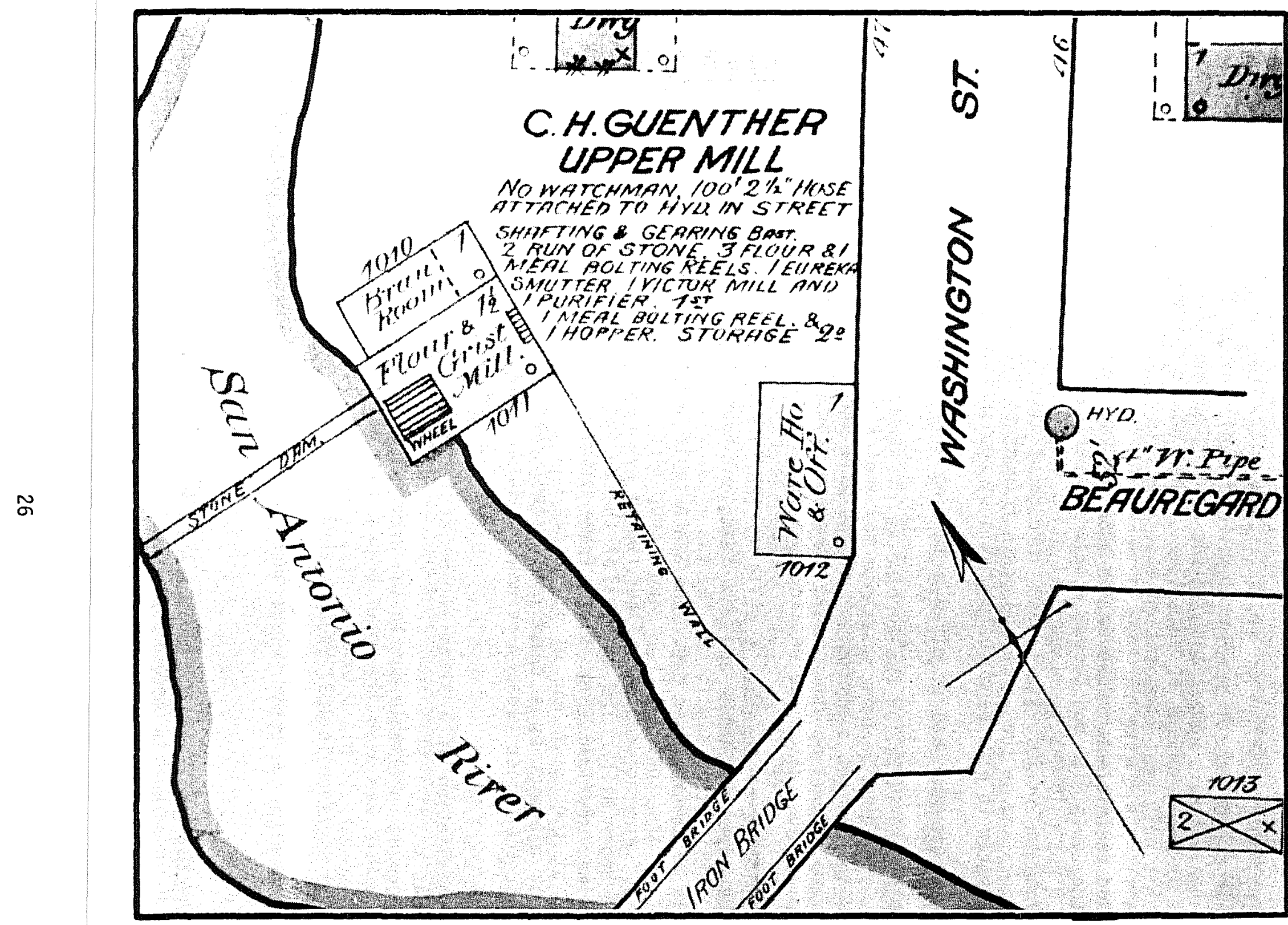

Figure 7. Sanborn's Insurance Map of 1885 and 1888. The 1885 and 1888 maps were identical (Sanborn Map and Publishing Compnay, Ltd. 1885, 1888). 
ship our wheat in from 2 to 500 miles. So there was no profit after the wages had been paid.

Evidently the arrival of the railroad lines had not completely solved Guenther's problems of supply, despite a rapid growth of population in the San Antonio area. Competition in the milling business would also have played a part in his problems at this time. When he first came to San Antonio in 1859, his only real competition was the Lewis Mill in downtown San Antonio (Table 1). This mill had been in operation since about 1845 and was out of date and inefficient. However, in 1860 the Laux Mill was built just upstream from the Lewis Mill and became a major competitor for the San Antonio market. In 1880 not only was the Laux Mill still competing, but two other mills were in operation or just starting. Throughout this time, other smaller mills were operating on the north and south fringes of the San Antonio market area. These appear to have been custom mills of comparatively small capacity.

In 1880, Guenther had acquired a turbine that was no longer needed at the Water Works in Brackenridge Park (San Antonio Express 1926). Sometime afterwards he installed the turbine at the Upper Mill, in place of the water whee1. The 1888 Sanborn insurance map indicates a water wheel at the Upper Mill (Fig. 7), yet a photograph of the mill made about that same time shows the frame supporting the turbine in place (Fig. 8). Perhaps the renovation took place just after the research was done for the map.

A description of Guenther's mills in 1887 (Morrison 1887:132) reports that they employed 20 hands and six teams of horses hauling flour, meal, and grain. The total capacity of the two mills was 120 barrels of flour and 400 bushels of cornmeal per day. The San Antonio and Aransas Pass Railroad had a depot at the Lower Mi11. The Lower Mi11, "equipped with full roller process," manufactured only flour, while rye flour and cornmeal were produced at the Upper Mill. The offices of the business were at the Upper Mill at this time. By 1896 (Fig. 9), a frame building had been constructed for an office at the south end of the Upper Mill property. Perhaps one of the earliest attempts by a commercial establishment to fit into a residential setting, the office closely resembled houses being built in the area at that time.

The installation of a steam engine at the Lower Mill (Beckmann 1951:8) in 1894 was a major step away from dependence on the flow of the river, which was becoming unreliable due to the numerous demands of the rapidly developing town. This was also the year that Arthur Guenther left the firm, signing over his share to his brother, Fritz (BCDR Vol. 137:181). The untimely death of Fritz Guenther in 1897 brought about a major reorganization. The youngest Guenther son, Erhard, came into the business in 1898, and the firm became C. H. Guenther \& Sons, known now as the Pioneer Flour Mills (Beckmann 1951:44).

Evidently the Upper Mill ceased grinding about 1900, as that was the first year it was not 1 isted in the San Antonio City Directory. After the death of Carl H. Guenther in 1902, Erhard became president of Pioneer Flour Mills (Beckmann 1951:48). Soon after this, the Upper Mill was leased to the San Antonio Macaroni Factory (Appler 1903-1904). The mill buildings were used as the basis for the factory, with a number of additions, including a two-story 
TABLE 1. MILLS IN SAN ANTONIO IN THE 19TH CENTURY

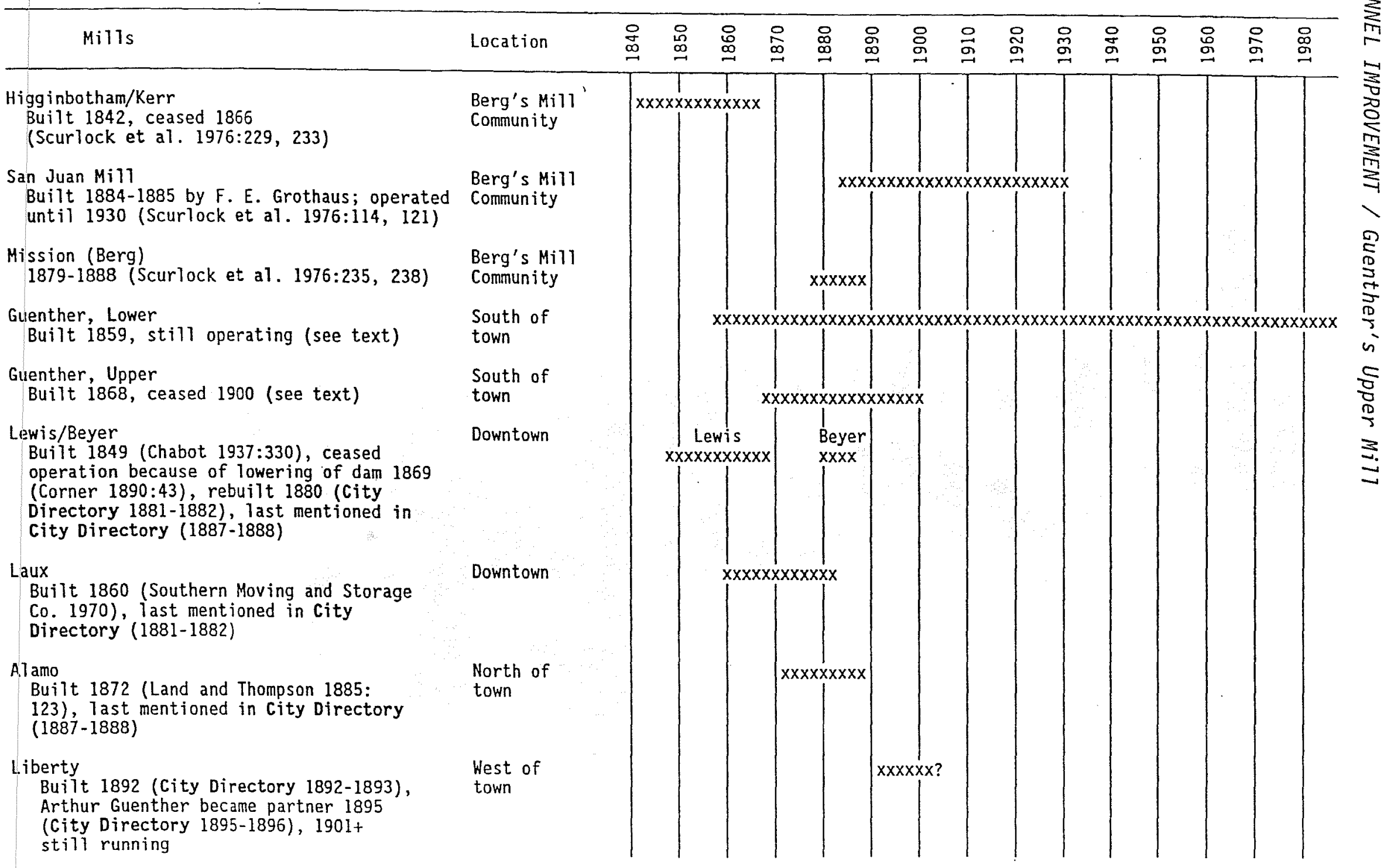




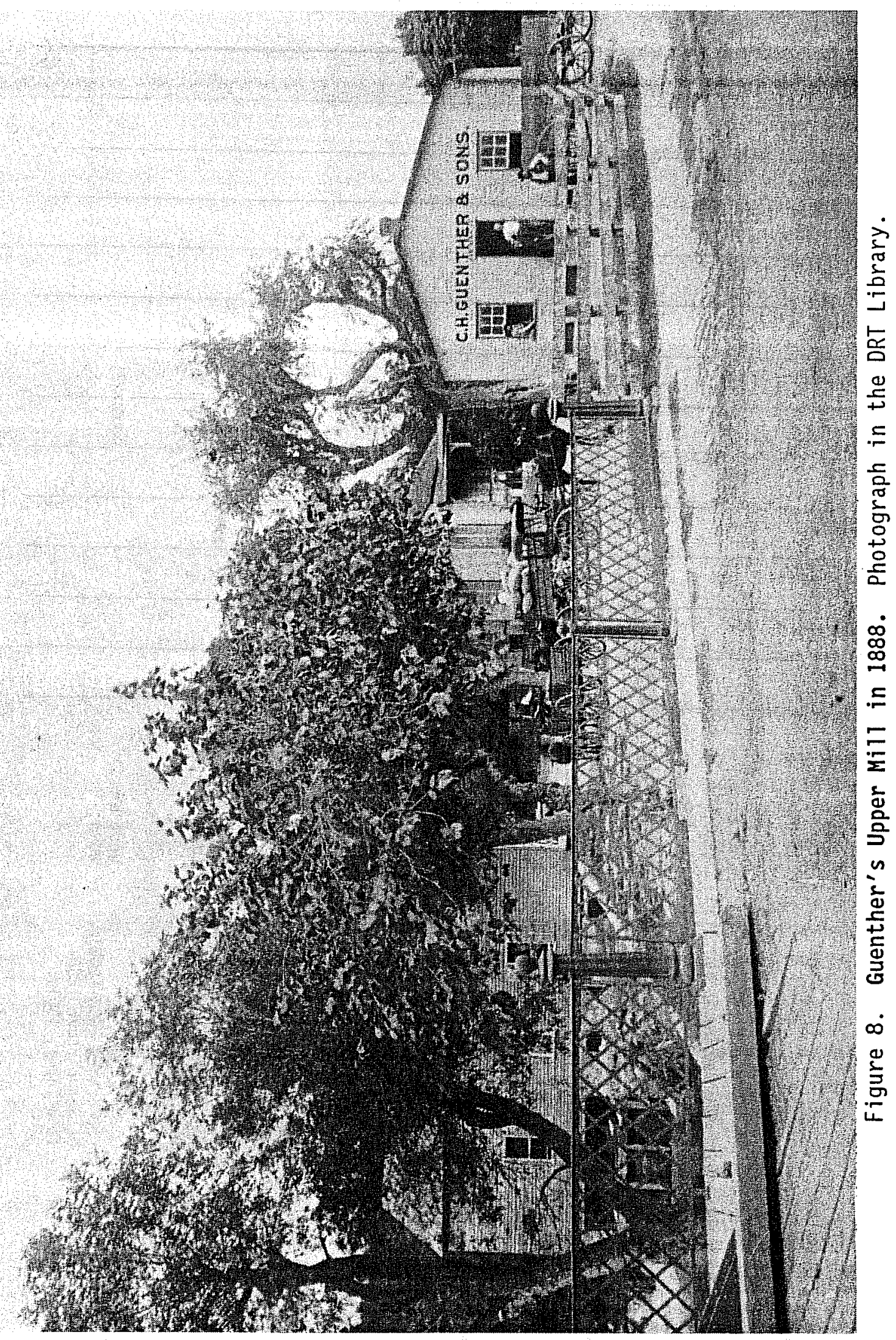




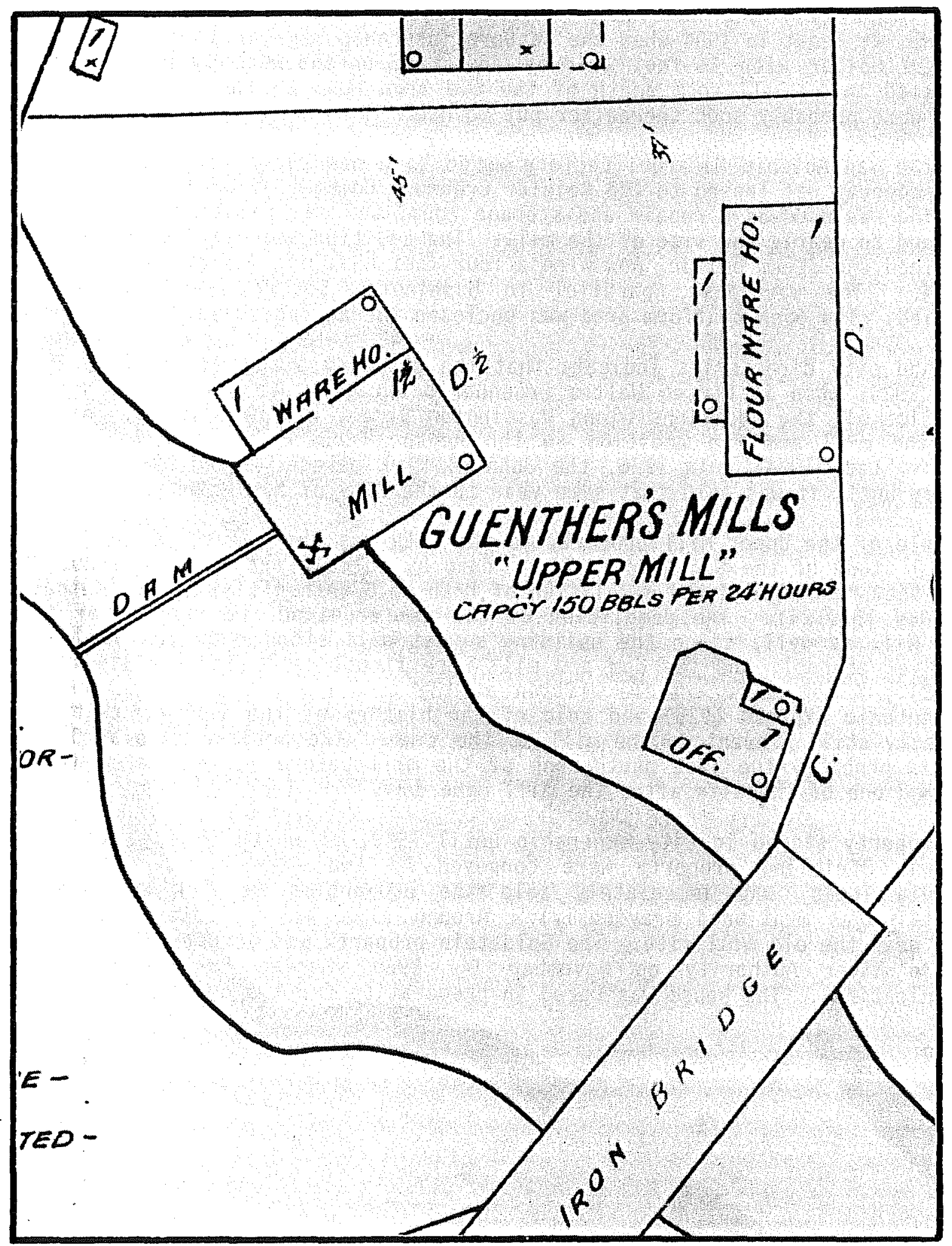

Figure 9. Sanborn's Insurance Map of 1896. Taken from Sanborn Map and Publishing Company, Ltd. (1896). 
warehouse and a two-story building to be used for air-drying the pasta (Fig. 10). Apparently the machinery in the factory was powered by the mili turbine, at least in 1904 when the Sanborn insurance map was drawn. However, a steam boiler with 15-foot chimney and a 25-horsepower engine had been installed in a small room north of the old bran room on the mill building. These were probably soon thereafter put to use.

When the San Antonio Macaroni Factory moved to a new plant in 1910, the old mi11 property was leased to the Reigler Creamery Company (Fig. 11). The mi11 building was used as a repair and storage room, and the former bran room was enlarged to nearly the size of the mill. The addition was all iron clad. It contained the steam boiler, now with a four-foot chimney, and a 20-horsepower engine. The warehouse, parallel to Washington Street, was once again modified. The open platform area was enclosed for an ice house.

Maps and city directories indicate that the property stood vacant from 1915 until 1924, when it housed Walter Froehner's Garage. At some point during this time all the additions along Washington Street had been razed, leaving only the mill and the addition on the north (Sanborn Map and Publishing Company, Ltd. 1924). In 1926, the John W. Kirk Garage leased the property briefly until it was sold that same year to the City of San Antonio.

The sale of the Upper Mill property to the City was the result of the flood control study of the San Antonio River done by Metcalf and Eddy in 1920, in which they recommended the demolition of both of Guenther's milidams (Metcalf and Eddy 1920:24). The demolition of the dam required the removal of the Upper Mill as well, since the building's west wall stood over the falls in the river channel, and the dam and mill were structurally interrelated (see Fig. 2). A newspaper article written at the time described the demolition (San Antonio Express 1926) and told of the history of the turbine that was evidently still present in the mill at the time. The article also includes what is probably the last photograph of the mill before it was razed (Fig. $12)$, and one of the site after the mill came down.

The property stayed in City ownership until 1940, at which time it and the original Stribling property were conveyed in two parcels to Louis and Virginia Theis, who immediately sold the properties to Eli and Aileen Goldstein (as mentioned previously). Around 1950, the Goldsteins built a house near the old mill site. The Goldstein property was acquired by the San Antonio River Authority on November 14, 1980 (Dorian French, personal communication). The house was razed in preparation for the current project. 


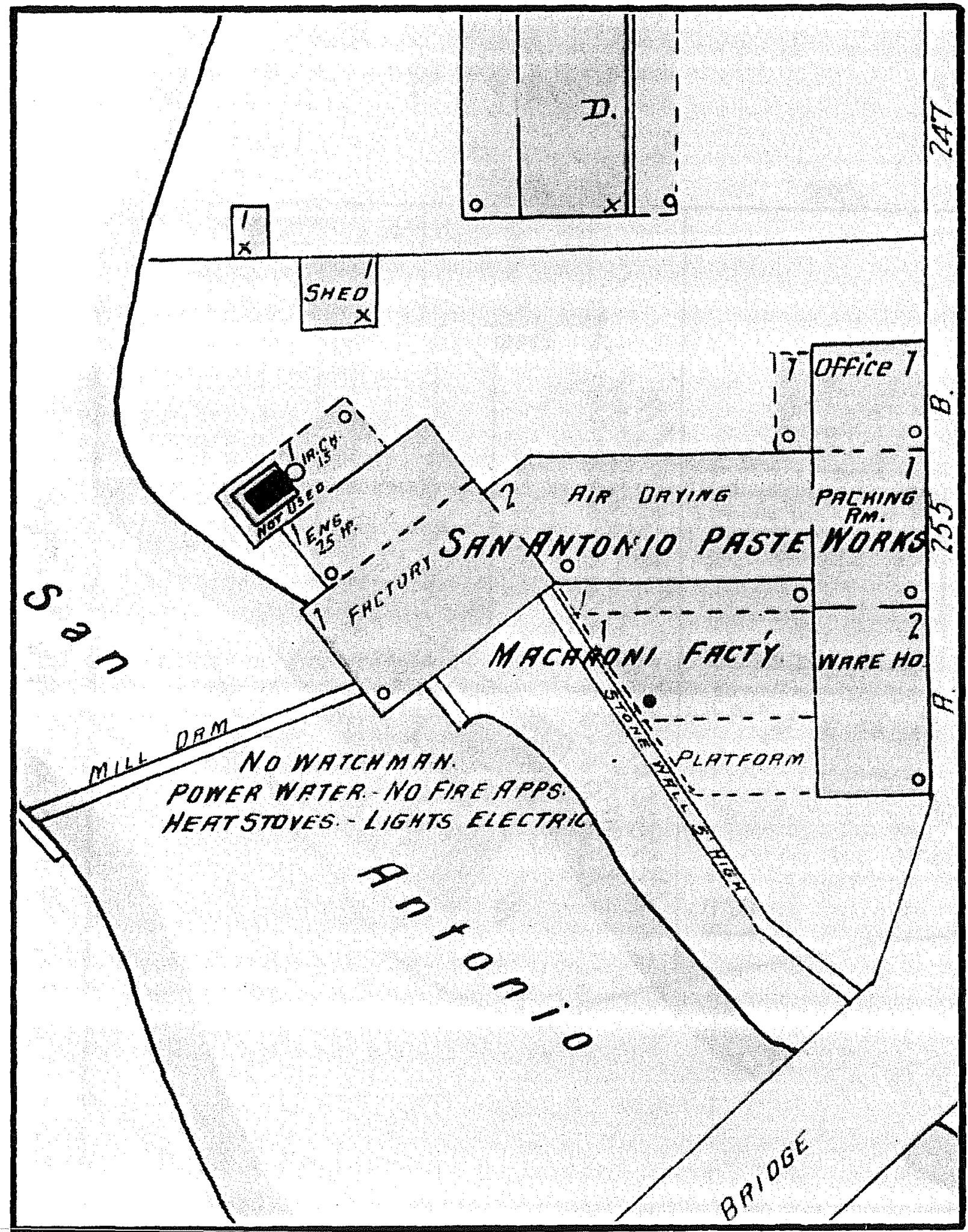

Figure 10. Sanborn's Insurance Map of 1904. Taken from Sanborn Map and Publishing Company, Ltd. (1904). 


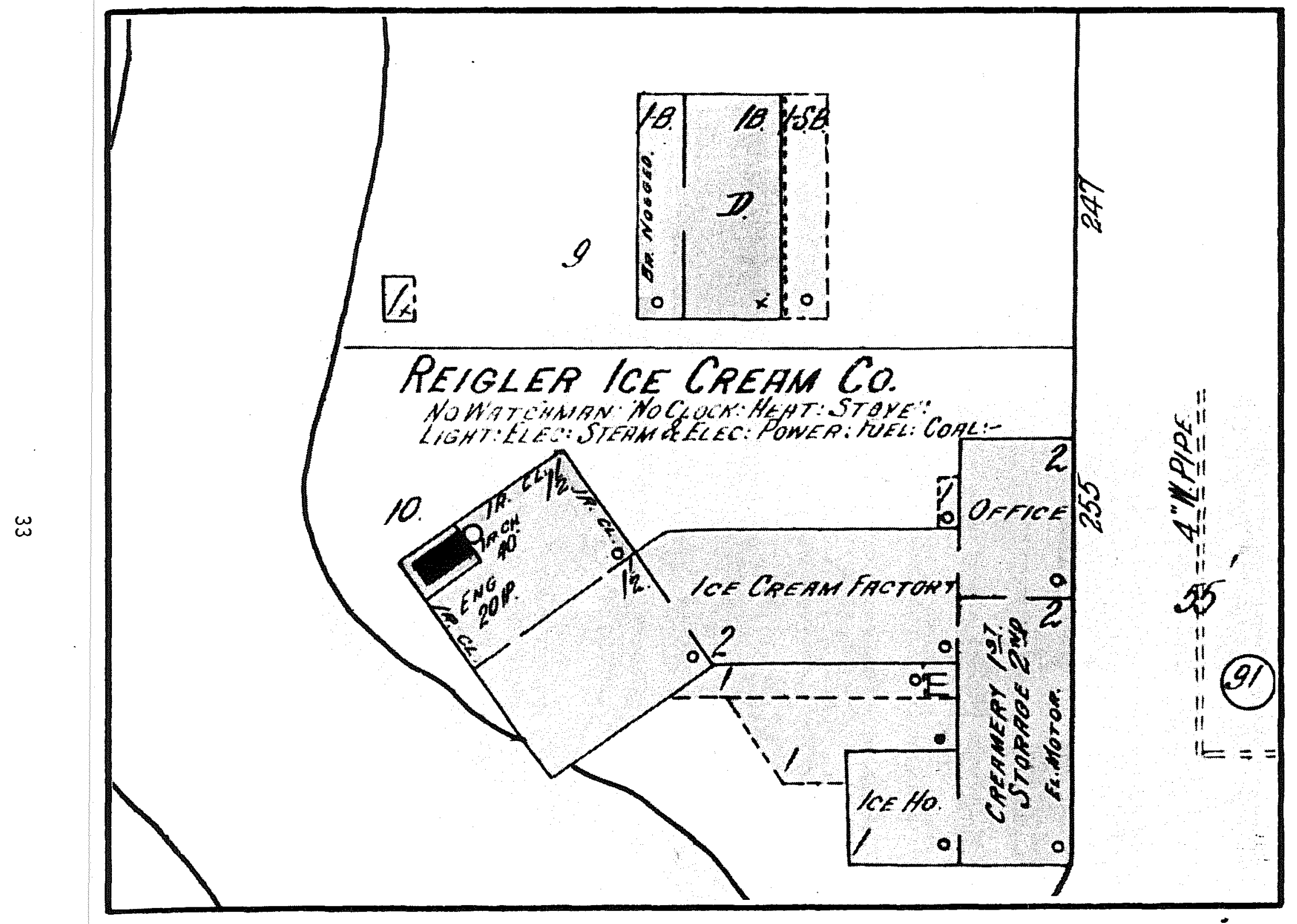

Figure 11. Sanborn's Insurance Map of 1912. Taken from Sanborn Map and Publishing Company, Ltd. (1912). 


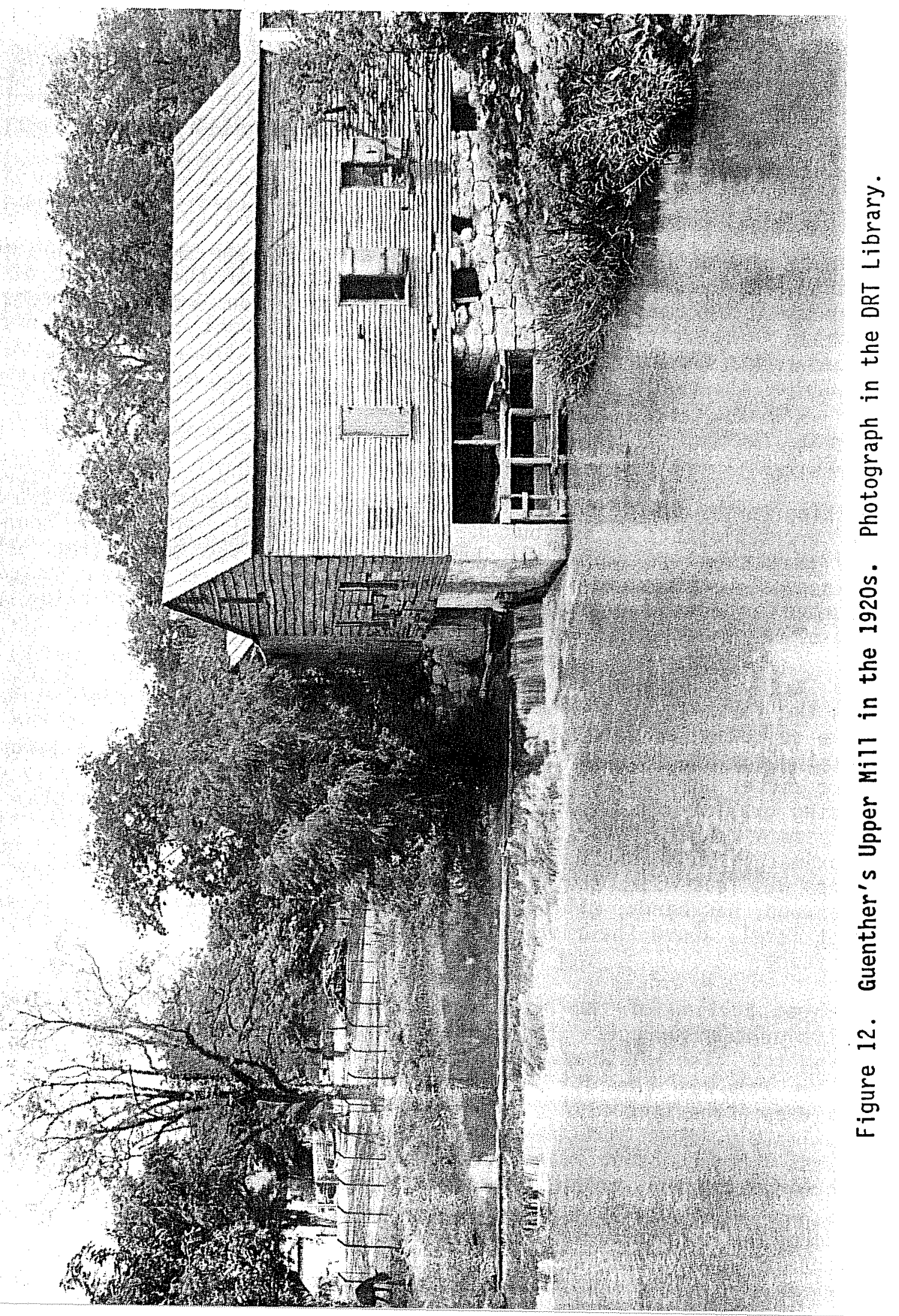




\section{ARCHAEOLOGY AT THE MILL SITE}

During 1981, the entire project area on either bank of the river from Nueva Street on the north to Johnson Street on the south was examined by surface survey and selected shovel tests. Due to severe erosion and tp the channelization of the river in 1926, no cultural resources were found that would be affected or endangered by the flood control project.

Prior to undertaking the field survey a thorough archival search was made. This included an examination of deed records and property sales, the Sanborn insurance maps of 1889,1904,1917, 1935, and 1952, and the Koch maps of 1873 and 1886. In addition, records of the Daughters of the Republic of Texas Research Library and the San Antonio Conservation Society Library were searched. The results indicated that no significant structures had been located within the survey area and that a11 extant structures dated to after the turn of the century and were of no particular architectural significance.

\section{SURFACE SURVEY AND SHOVEL TESTS}

A walking survey of the entire area of Unit 8-3-2 was conducted by two Center staff archaeologists on various days during May 1981. The area, bounded by Nueva Street on the north and Johnson Street on the south (Fig. 1), was examined as closely as overgrowth would permit, and shovel tests were conducted as seemed appropriate. The following is a description of the right-of-way as encountered.

Nueva Street to Toile Road and Woodward Place: From the Nueva Street bridge south the first 40 to 50 feet were enclosed in the high concrete embankment of the spillway for flood gate Number 5 which holds the river at the proper level for the Riverwalk area, some 10 to 15 feet higher than the lower river to the south. Below the spillway, the banks of the river were deeply eroded, exposing grayish black soil and rubble overlying yellowish gravels. Below this eroded zone, the river on either side shelved out into terraces approximately five feet above normal river level. On the east bank the terrace was less wide, heavity overgrown with brush and numerous large trees, cottonwood, hackberry, willow, and chinaberry predominating. On the elevated street level, above the river, the frontage is completely enclosed by chainlink fence.

The first portion of the block was occupied by an Allright parking 1ot, a level blacktop surface. The next portion was covered by the Hermann Sons parking lot, also blacktop, some four feet lower than the first. Next to the parking lot was the Jordan Ford complex of parking lots and service facilities. The Koch $(1873,1886)$ maps of this area indicate the presence of approximately three structures near the river in 1873, and seven in 1886. The west terrace, about twice as wide as the east terrace, was again heavily overgrown, with hop, walnut, pomegranate, and hackberry trees predominating. There was also an extremely dense undergrowth of giant and native cane covering the entire river bank. Again the high street level portion was enclosed by chain-link fence backed by parking lots extending to the last lot facing on Woodward Place. The house occupying that lot (125 Woodward Place), a two-story wood frame home with standing seam metal roof, appeared to have 
been constructed in the 1920s or 1930s. There were no structures indicated in this area in either the 1873 or 1886 Koch maps.

Woodward Street to Guilbeau Street: The home at 126 Woodward Place had already been razed at the time of the survey, and the foundation had been removed to a depth of four feet. No evidence of previous occupation or structures was evident. The house fronting Guilbeau Street (337) was an antebellum style frame with two-story Corinthian columns in front, again appearing to have been constructed shortly after the turn of the century. The river banks were again graced with several large walnut and chinaberry trees and dense underbrush.

Guilbeau Street to Durango Boulevard: The four houses facing Aubry Street were all frame with standing seam metal roofs. All appeared to date to the early 1900s. The few standing structures behind the houses seemed to be contemporary with the houses. The dense growth along the river continued, the trees heavily festooned with wild grape vines. No structures were visible here in either the 1873 or 1886 Koch map.

Toile Road to Durango Boulevard: The area from Toile Road to Durango Boulevard, occupied by KWEX-TV, was recent fi11, created by the river channeTization of the 1920s when the river bend above the King William area was straightened. The bank was reinforced with wooden and concrete barricades. Under the Durango Boulevard bridge there were two rows of wooden pilings visible in the riverbed. Their purpose is unknown, since the Martinez Street bridge (ca. 1930) which it replaced, was a single span of reinforced concrete. The Koch maps of 1873 and 1886 indicate that three to five buildings once stood in this area.

Durango Boulevard to Washington Street: The east bank of the river was a wide terrace covered with a low growth of Johnson grass, Queen Anne's lace, and numerous annuals; a sloping bank rose rather sharply to the rear lot lines of the houses on Washington Street, primarily created by the 1926 channelization. The northwest corner of the Oge lot (209 Washington Street) wi11 be affected by the project, but this is recent fill. Behind the house, a modern wrought iron gazebo may be within the temporary right-of-way. Next to this lot is situated the Blersch/Watson house (213 Washington Street), one of the oldest homes in the area (Burkholder 1973:70). A portion of the back yard is banked by cut 1 imestone blocks and is approximately two feet higher than the present grade of the surrounding lots. The apparent age of the blocks and recent landscaping practices suggest that a portion of the lot is original surface level, and the adjacent areas have been sloped. Skipping the site of Guenther's Upper Mi11, which will be described elsewhere, we moved to the Arsenal Street bridge. It was noted that the foundation blocks of cut limestone for the first iron bridge of 1880 were partially in place in the bank and extending into the river. This bridge was replaced by the present bridge constructed in 1928.

Durango Boulevard to Arsenal Street: The wide west bank terrace, completely covered with a dense growth of high grass, native and giant cane, and willow trees, extends back to a high concrete retaining wall topped by a six-foot chain-link fence. 'Beyond this were the blacktop, crushed stone, and concrete parking lots of the former Arsenal. Several test corings were examined, but 
no cultural debris was observed. According to photographic evidence, this was a gentle, sloping bank used as pastureland from ca. 1880 to 1920 . Therefore the high embankment is most likely a result of post-1926 construction. There are no structures indicated other than the Arsenal building in 1873, but by 1886 a house and outbuildings are shown facing on Dwyer Street (Koch 1873, 1886).

Washington Street to Johnson Street: The east bank terrace continued, Tess densely covered, almost to Johnson Street, where the concrete retaining wall of the river channelization was again encountered. Several partially exposed stones observed prompted four shovel tests to a depth of six inches in the south portion of this area, but all were either isolated stones or recent fill. However, when the river level was lowered for excavation at Guenther's Upper Mill, cut limestone foundations were exposed at the water 1 ine just south of the bridge. They may be associated with a structure which appeared in this general area on the 1873 map by Koch (1873), but had disappeared by 1886 (Koch 1886).

Disposal Area: The designated disposal area and haul road were examined extensively, and 10 shovel tests were conducted to a depth of eight inches. Archival research revealed that the lower basin is the bed of the old river channel prior to diversion and previous fill episodes. The area is heavily strewn with cut limestone block and other construction materials from structures apparently dating from the late 1800 s until the mid-20th century. There appears to be a minimum of six feet or more of previous fill. No areas of historical significance were recorded. If fill is limited to the designated limits, and proper access 1 imitation to the haul road is observed, no impact to prehistoric or historic resources should result.

\section{PRELIMINARY WORK AT THE MILL SITE}

Work on the mill structure was divided into several operations. First, the visible structure in the riverbed was totally recorded as found, and excavation was done to examine the structure buried in the bank. Then all the loose stones that had fallen into the forebay and wheel pit and the area directly surrounding were removed, and the uncovered area was recorded again. All of the mill structure in the river channel was then removed and stored on the upper terrace. And finally, the west wall of the wheel pit was rebuilt in the newly constructed river channel.

When the archaeological crew arrived on the site, the Goldstein House had been demolished and removed. The upper terrace was an open, grassy area under large trees (Fig. 13,b). The river bank was covered with a thick growth of weeds and vines. Species of vegetation noted on the site included pecan, elm, live oak, black walnut, chinaberry, willow, hackberry, fruitless mulberry, fig, papaya, giant cane, bamboo, ice weed, and various grasses and vines. The slope below the upper terrace was cleared by the crew for a distance of approximately 100 feet along the bank in the area where the mill structure was estimated to lie. The west foundation wall of the mill was represented by a low stone wall about 15 feet from the bank, and traces of other walls were visible in among the loose stones and in the river trash that had accumulated on the site (Fig. 13,a). There was no trace of the 


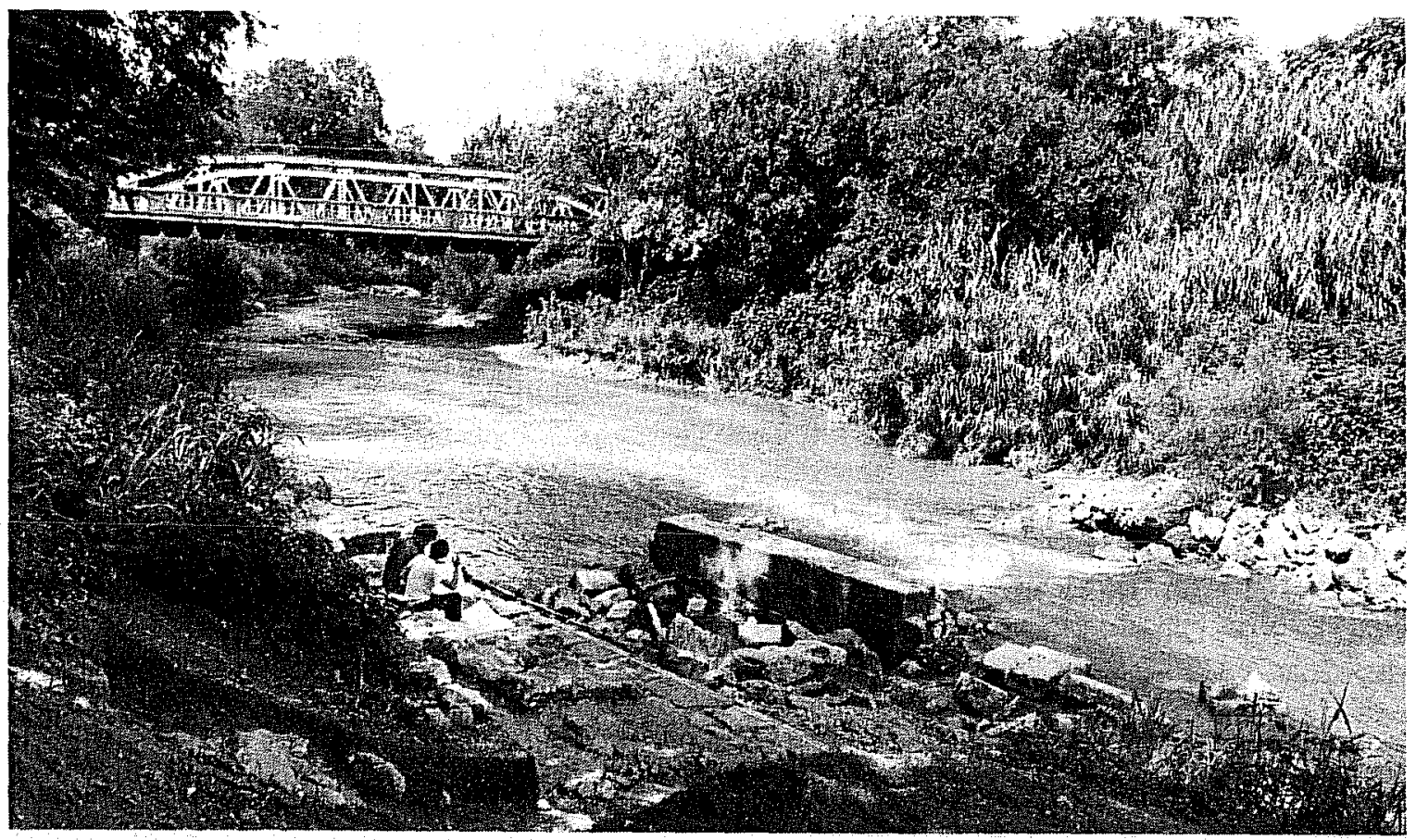

a

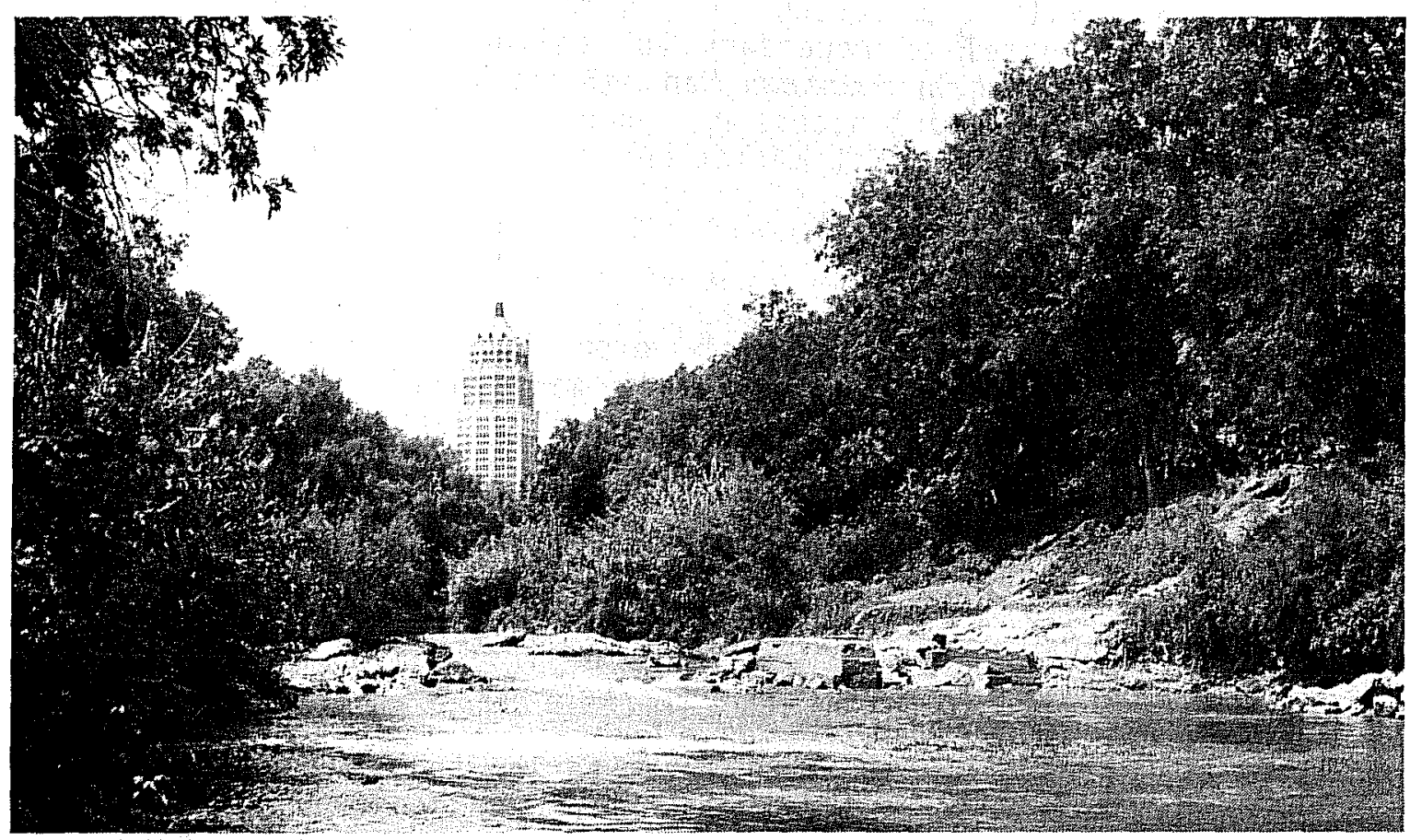

\section{b}

Figure 13. The Mill site at the Start of Investigations. a, looking south toward Arsenal Street bridge; $b$, looking north toward downtown San Antonio. 
related mill structures on the upper terrace. It was anticipated that quite a bit of fill had been hauled in to cover the site at some time in the past, perhaps in connection with the building and landscaping of the Goldstein House in the 1950s.

The Upper Mill was constructed ca. 1868 and remained in remarkably good" condition until it was razed in 1926. The walls of the river or basement level were built of cut limestone blocks, and contained the forebay and wheel pit on the west side. There was probably at least a partial basement on the east side, since openings are visible in photographs of the south foundation wall (see Figs. 6 and 8 ).

About four feet of the west wall of the mill structure was still standing in the riverbed. The bases of the north and east walls of the forebay/wheel pit and the dividing wall between them were also preserved. The water in the river was low, and glimpses of some sort of wooden structure could be seen in the bottom of the wheel pit beneath a jumble of loose cut limestone and rubble.

It should be mentioned here that the level of the water in the river varied from day to day depending upon the management of the control gates upstream. This was brought home to the crew rather forcefully one day when they looked up from their work to see a wall of water approaching, the result of the operator opening a control gate. For this reason it was important to keep in close communication with the persons in charge of this operation. (The control of the river gates is necessary to monitor the level of the river within the Riverwalk area in downtown San Antonio.) The field work had to be planned around the resultant necessary flooding of the lower terrace after a significant rain when water must be let out to avoid flooding in the town.

\section{THE MILL EXCAVATIONS}

After the bank had been cleared of brush, excavation units were laid out so as to locate and examine the corners of the mill itself and the bran room that stood against its north wall (Fig. 14). These were extended as needed to obtain information on the construction of the foundation and its present condition. Since there had been some discussion about rebuilding the mill in the future, observations were carefully recorded for possible use by architects and/or engineers.

\section{Unit 1}

Unit 1 was a 50 - by 50 -inch test excavation to Tocate the foundation of the south wall of the mill and to study the stratigraphy of the deposits that overlaid it. A three-inch layer of dense black clay containing contemporary plastic and aluminum artifacts comprised Layer 1 . The second Tayer varied from seven to nine inches in depth. It was a dark brown clay containing gravels, cut nails, and recent coins. Layer 3 was three to nine inches of brown clay with yellow gravels, cut nails, and an iron spike. At the bottom of this layer, a wall of rubble stone was found, lying north-south along the east side of the unit. Approximately 20 inches of the wall extended into the 


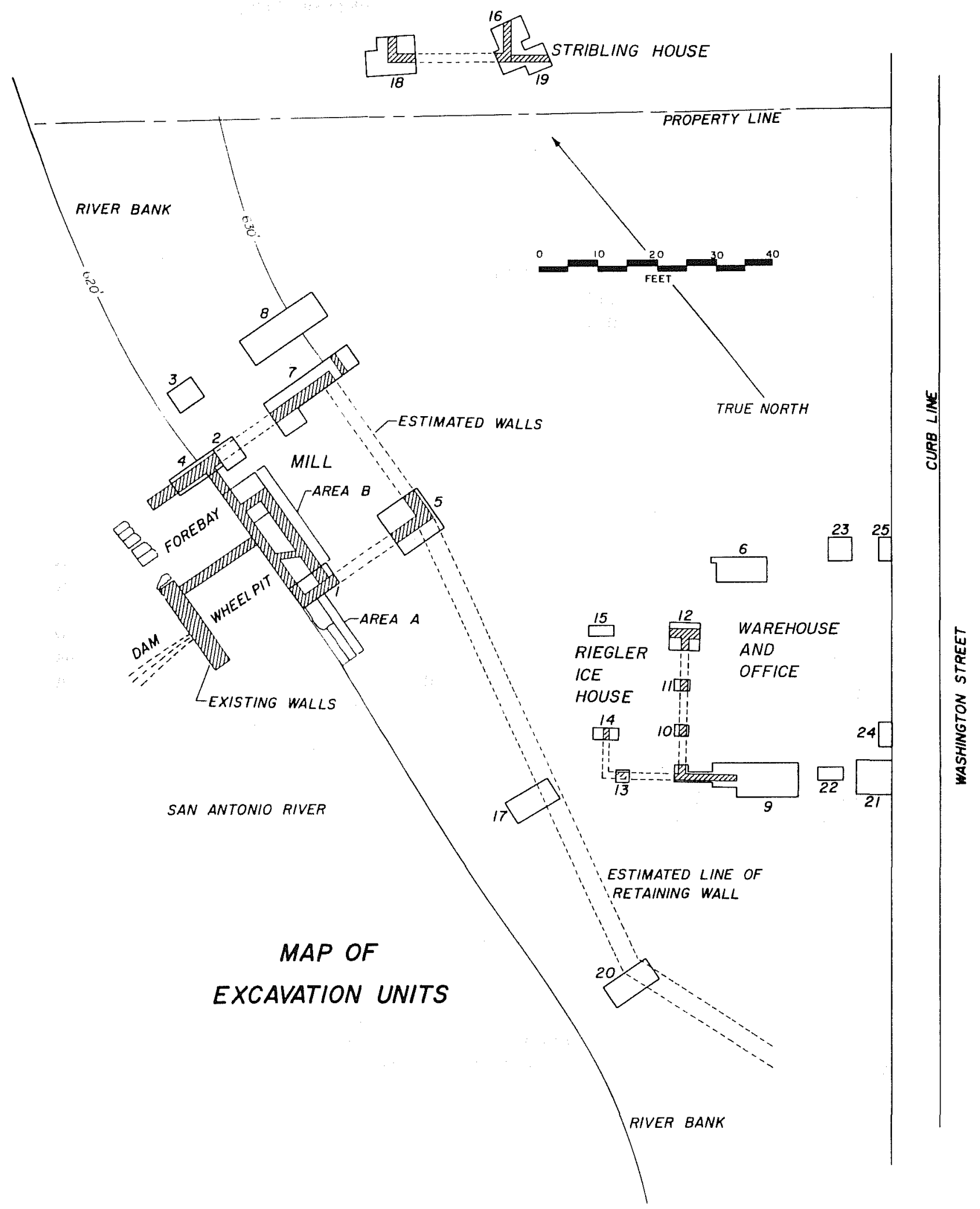

Figure 14. PIan Map of Relationship of Excavation Units. For topographic relationship, see Figures $13,16, a$, and 18 . 
unit. Then the soil to the west of the rubble stone foundation was removed as Layer 4. This consisted of dark brown clay with pebbles. At 18 inches below the top of Layer 4, the cut stone south wall was encountered, running east-west. The wall appeared to end near the west edge of the unit, but when the unit was extended 25 inches west to the edge of the bank and Layer 4 was excavated 18 inches deeper, the wall was found to extend to the bank and corner there, going north. The wall was 20 inches wide. Beneath Layer 4 was a hard-packed brown clay, Layer 5, that was found to be the original, sterile soil into which the mill foundation was built.

Layers 1 and 2 appear to have been fill, either brought in from another location to cover the site or washed in by flooding. Layer 3 was deposited during or soon after demolition, being in and around foundation remnants and partially filling the space between the rubble stone wall and the east wall of the wheel pit. Layer 4 was the initial deposit over the mill remains during demolition. It contained glass and metal debris that was probably related to the mill.

\section{Area A}

A 30- by 120-inch unit south of Unit 1 and extending east from the river bank was designated Area A. Early photographs of the mill show a terraced stone retaining structure along the south face of the mill (Fig. 6). This area was cleared to see if any of the structure remained.

The fill (Layers 1 and 2) was shoveled off. The remains of the foundation for the lowest terrace step of the retaining structure were found south of and eight inches lower than the top of the mill's south foundation. The cut stone terrace at the edge of the river bank extended an additional nine feet to the south. For the first 40 inches east of the edge of the bank the terrace was made up of three courses of stone with a total depth of 32 inches. The remainder consisted of one course six inches in depth (below the water line in Fig. 12). The west face of the terrace structure had a layer of Portland cement. The structure was bounded on its south edge by traces of a wooden fence or retaining wall.

The fence traces consisted of several slightly overlapping wooden planks. The bottom edges of the planks closest to the retaining structure were 12 inches deeper than the bottom of the stone structure. The fence followed the contour of the bottom stone of the retaining structure, going east into the bank.

Several of the planks were tapered to a point, probably indicating they were hammered or driven into place. They penetrated an eight-inch layer of brown clay with cobbles and were embedded in the layer of gray clay below it. Several of the planks had cut nails driven through them and bent upward on the backs of the boards. No fence posts or rails were found in association with the planks, which may indicate that the planks had been previously used el sewhere.

The fence appears to be fragments of a board retaining wall that ran parallel to the south face of the first level of the stone retaining structure. An 
early photograph also shows the top edge of a wooden retaining wall visible along the bank for approximately another 100 feet south of the stone-terraced structure. The wooden wall probably served to prevent undermining of the bank in front of the terrace by turbulence from the turbine, and was similar in construction to the row of planks found across the forebay. This sort of plank construction was customary to prevent undermining of mill structures.

\section{Area B}

An area 75 by 200 feet north of Unit 1 was designated Area B (Fig. 15,a,b). The purpose of this unit was to expose and follow the top of the east foundation of the forebay/wheel pit and that of the foundation paralle 1 to it on the east. The fill was removed across this area in a single operation.

Beginning at the inner face of the south foundation wall and running for 16 feet eight inches to the north, the easternmost wall was constructed of random-sized limestone and sandy mortar with several patches of Portland cement. The foundation at its north end turned west and butted against the forebay/wheel pit wall.

A base for machinery or gearing was found within the space outlined by the wa11. The base's west edge sloped eight inches upward from south to north and from northwest to northeast. It was constructed of 1 imestone blocks and sandy mortar. Portions of its surface were plastered with Portland cement, and metal fasteners were anchored into the masonry. There were traces of a cement 1ip on its north wall and a 12-inch-wide concrete-reinforced rubble limestone wall along its south edge which was 15 inches higher at its west end than at the east wall. The south wall of the machinery base was probably higher before demolition of the mill. The brown sterile soil adjacent to this wall was left in place for support (Layer 5 in Unit 1).

The machinery base was probably originally the location of the gearing for transfer of power from the horizontal shaft of the water wheel to the vertical spindle that drove the millstones (see Fig. 4). When the turbine was installed, it would no longer have been used.

\section{Unit 2}

Unit 2 was a 50 - by 50 -inch unit placed to test for the northwest corner of the mill and the west foundation of the bran room. It was on the alignment of the north wall that extended into the river channel (Fig. 14).

Layer 1 consisting of dark brown clay fill was shoveled out. Layer 2 was a gray white sterile clay containing pebbles. Ten inches from the east face of the unit, a slight change in color was observed. A 20 -inch square shove 1 test in the southwest quadrant hit sterile caliche 10 inches below the top of Layer 2. An additional eight inches, Layer 3, was removed but no wall was found. 


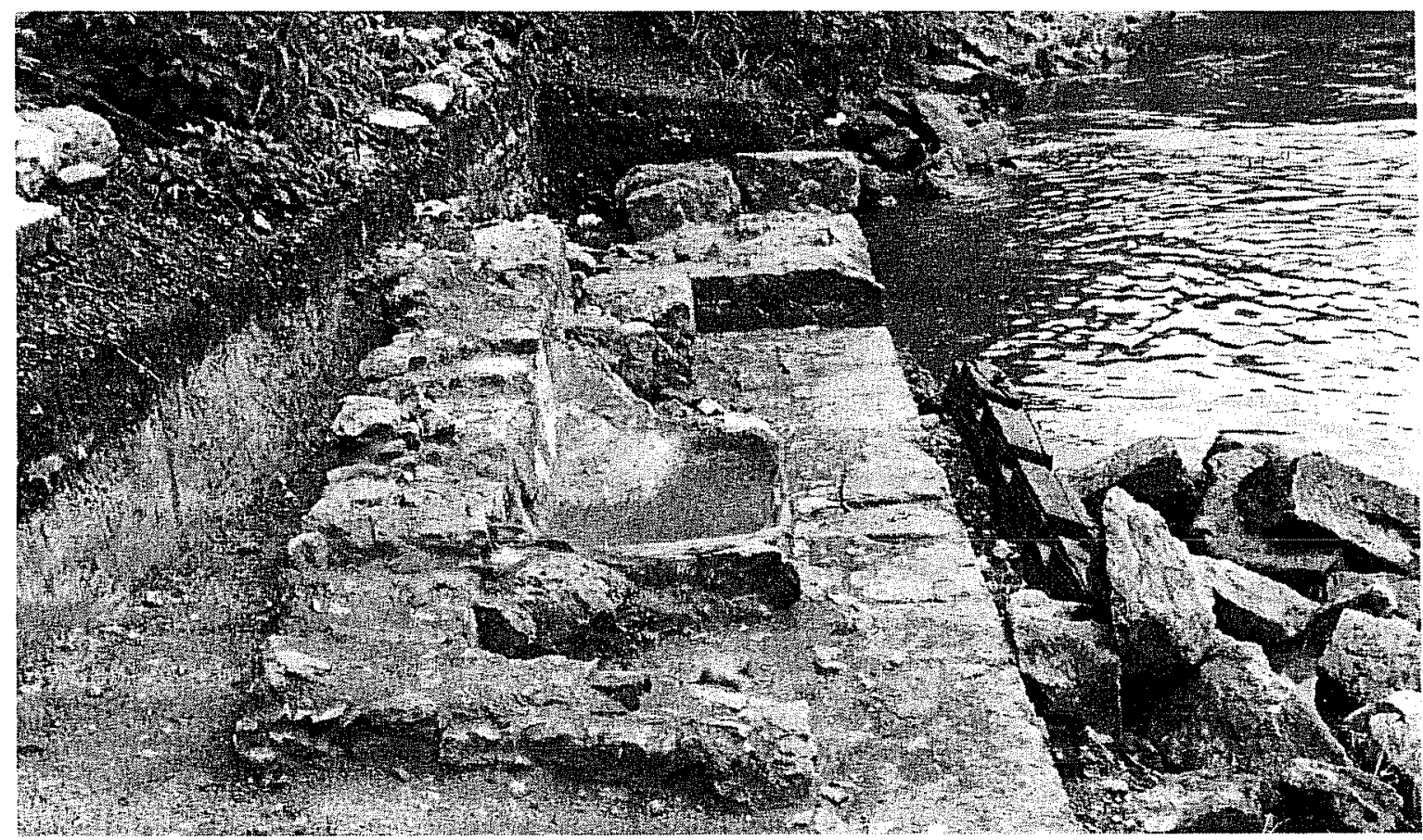

a

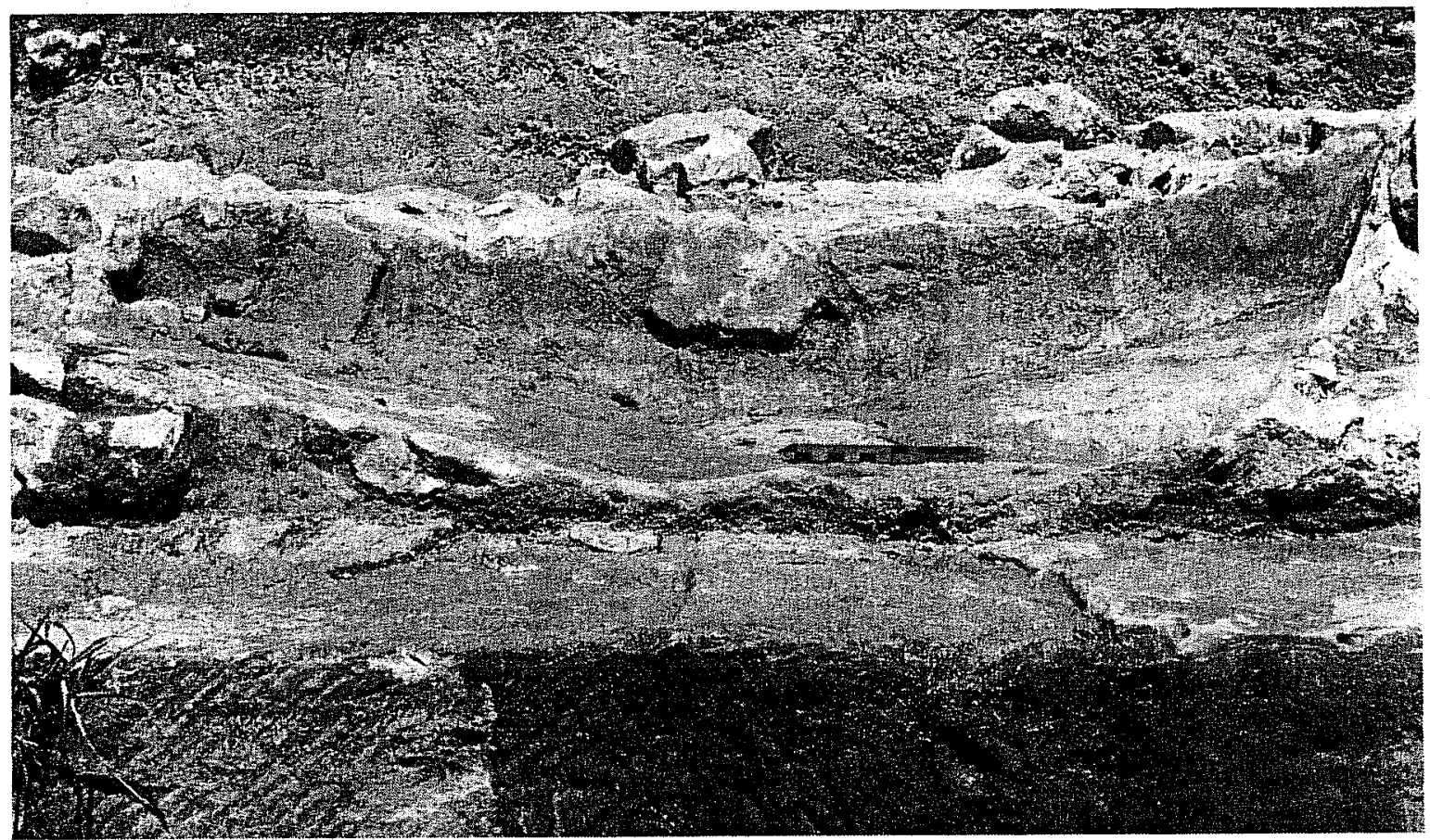

b

Figure 15. Views of Area B. a, looking south; b, close-up of machinery area looking east. 


\section{Unit 4}

Unit 4 was a test trench running eastward from the point where the north foundation wall disappeared into the bank, to the west of Unit 2 . It was 40 inches wide and approximately nine feet long.

The dark brown fill, Layer 1, was shoveled out. It varied in depth from 18 inches to 20 inches. Layer 2 consisted of gray white clay with pebbles and random pieces of limestone. Except for the limestone fragments, it was the same soil designated Layer 2 in Unit 2. The north foundation was found two to four inches below the surface of this layer. Layer 2 was found to be 12 inches deep, below was white caliche, Layer 3 . Twenty-two inches of Layer 3 were removed, taking it to a depth of six inches below the top of the north wall foundation. The foundation was set into a footing trench 40 inches wide and 22 inches deep, which had been dug into the caliche, then refilled with the same material. No artifacts were found in the footing trench.

The north wall foundation (Fig. 16,a) ran west for seven feet beyond its junction with the east foundation of the forebay/wheel pit wall. The surface of the north wall was uneven, and there were deep scrape marks on several of the stones. The bottom of the foundation of the forebay was set much deeper into the ground than that of the structure to the east. No trace was found of the bran room foundation.

\section{Unit 3}

Unit 3 was a 50 -inch square set on the most probable alignment of the bran room's west wa11. The dark brown fill, Layer 1, was shoveled off. Contemporary artifacts were mixed throughout this fill. Layer 2 , the same white gray clay with pebbles encountered in Units 2 and 4 , varied in thickness from 6 to 13 inches. Its top surface was fairly level; its bottom surface was lower on the west side of the unit. The change in level matched the alignment of a bulldozer cut noted in Layer 2 of Unit 2 and in Area $B$. No evidence of a structure was found in this layer. Excavation continued in the west half of the unit. Layer 3 was a mixture of light gray to gray white clay with a heavy concentration of concretions. Twelve inches of this was removed, but no structural remains were found.

Apparently the west wall foundation of the bran room, like that of the north wall of the mill, was not set as deeply into the ground as the section which housed the forebay and wheel pit. It was probabiy removed during the 1926 demolition.

\section{Unit 5}

Unit 5 was placed to test for the southeast corner of the mill and the retaining wall that butted against it. It was begun as a 50-inch square, but soon expanded into a 100-inch-square unit. Not all areas of the unit were excavated to the same depth, due to numerous large stones encountered during excavation (Fig. 16,b). 

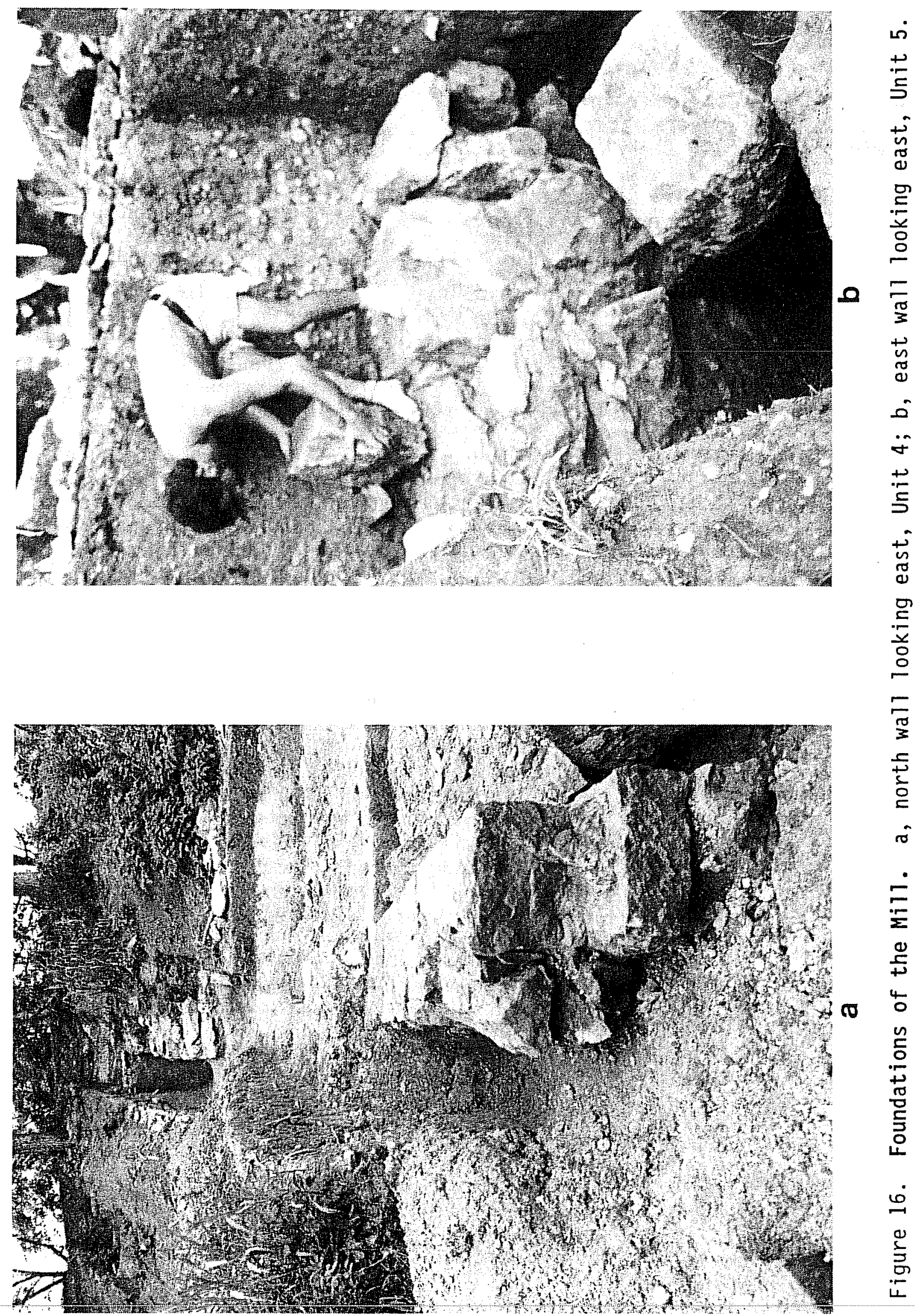
Layer 1, the dark brown clay fill, was shoveled out. Its depth varied from 45 inches to 74 inches in a slope downward from northeast to southwest. The upper third of this layer was a mixture of demolition debris and construction materials from the 1950s house. The rest of the deposit contained cinders, ceramics, glass, metal scrap, and random cut stone blocks, possibly from the mill demolition.

At a depth of 45 inches below the present surface, the east foundation wall was uncovered. It began in the northeast corner of the unit and continued along the east wall of the unit for three feet, then ended abruptly. We continued excavating, encountered it again at a depth of 74 inches, and followed it to the southeast corner. From this corner, the wall continued west for 90 inches, where it ended in a jagged edge. The soil between the top of the first foundation uncovered and the top of the wall where it was found again to the south was arbitrarily called Layer 2, although there was no visible difference in color or texture from that of Layer 1.

To test for the joint with the retaining wa11, an area between the southeast corner of the mill and the southeast corner of the unit was excavated to a depth of 24 inches. Soil from this area was designated Level 3 . This soit was a sticky brown clay with sand and gravel, containing a mixture of glass, tin scrap, cut and wire nails. When no structure was found within the first two feet, the excavation was abandoned for more important work.

Layer 4, a 30- by 40-inch area at the inner corner of the foundation, was excavated to the depth of the bottom of the east and south foundation walls. Work was hampered by the amount of cut stone debris present in the fil1. This debris stopped at a six-inch layer of smooth gray clay with a surface of black clay and sandy mortar. Below this clay layer was a band of ash and cinders varying from one-half to two inches in thickness, overlying a sixinch layer of brown clay with limestone, river cobbles, and pebbles. Below this was the dark brown sterile clay, with pebbles, mortar, and bits of cut limestone embedded in its surface (Fig. 17). The wall was set in a footing trench dug through this surface. The trench extended 10 inches from the inner face of the wall.

The remaining east foundation wall was 24 inches wide and nine feet high, and was constructed of 1 imestone and sandy lime mortar. The upper three feet of this wall was of regular coursed ashlar; the next two feet below were coursed but with random sized and shaped stones. The final four feet were of random rubble construction. At the interface between the two latter courses of wall, there was a limestone ledge. This ledge protruded from the wall eight inches and was eight inches thick.

The south foundation wall was 20 inches wide and seven feet high, including an 18-inch footing. This wall had a similar limestone ledge beginning 38 inches from the southeast corner. The ledge was in alignment with the one on the east foundation. 

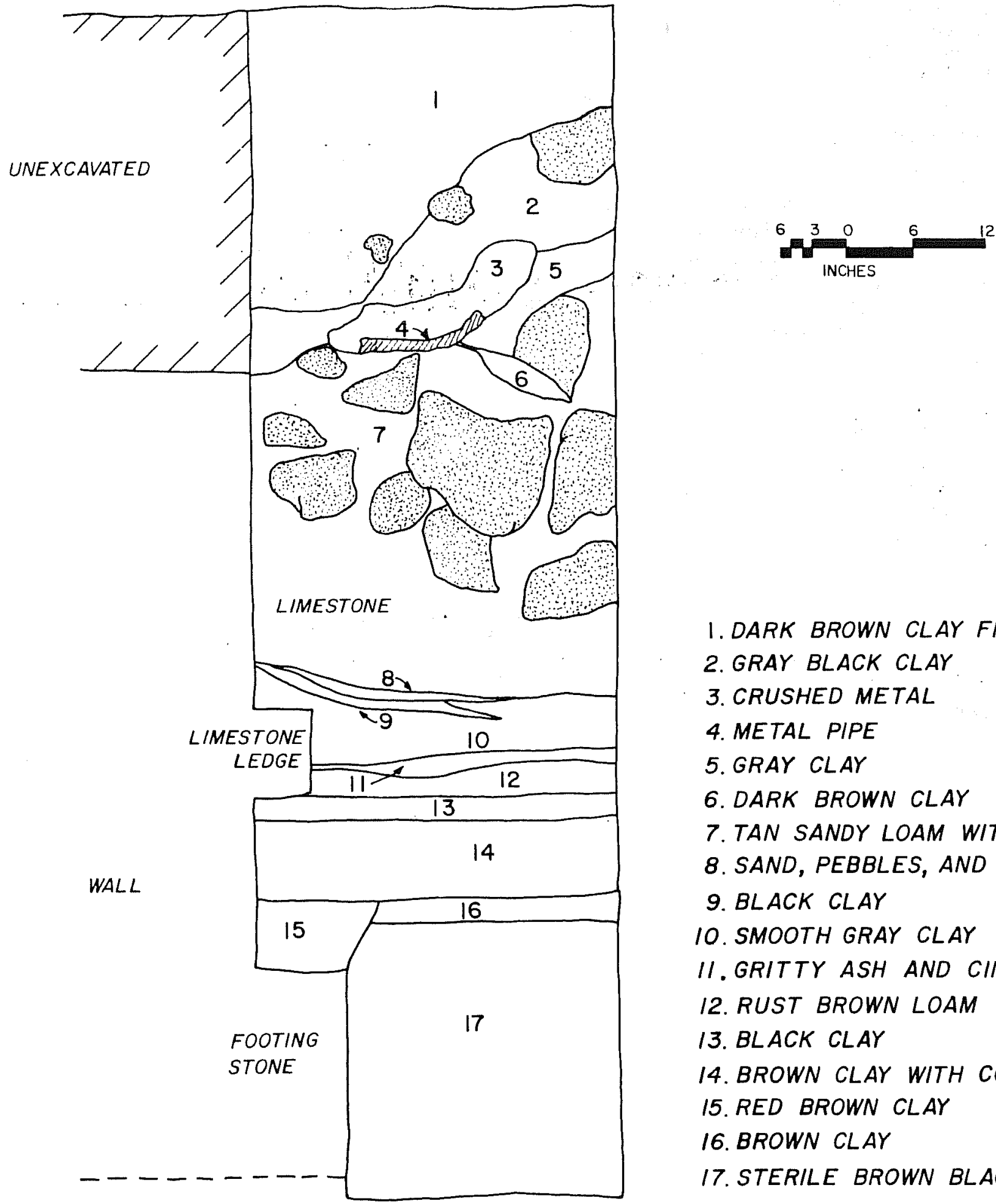

1. DARK BROWN CLAY FILL

2. GRAY BLACK CLAY

3. CRUSHED METAL

4. METAL PIPE

5. GRAY CLAY

6. DARK BROWN CLAY

7. TAN SANDY LOAM WITH MORTAR

8. SAND, PEBBLES, AND MORTAR

9. BLACK CLAY

10. SMOOTH GRAY CLAY

II. GRITTY ASH AND CINDERS

12. RUST BROWN LOAM

13. BLACK CLAY

14. BROWN CLAY WITH COBBLES

15. RED BROWN CLAY

16. BROWN CLAY

17. STERILE BROWN BLACK CLAY

Figure 17. West Wall Profile of Unit 5. 


\section{Unit 7}

Unit 7, a 50 - by 175-inch unit, was placed so that the most probable location of the northeast corner of the mill fell within the east edge of the unit. A 35 - by 45 -inch extension was added to its southern edge.

Layer 1 was removed following the slope of the hillside (Fig. 18). This was the same dark brown clay found in other units in this area. The northeast corner of the mill was found 65 inches from the east edge of the unit. The foundation in this area was built of large 1 imestone chunks and yellow mortar; unlike the foundations seen in Unit 5 , it had no cut limestone courses. The foundation was 24 inches wide.

The north wall stepped down irregularly to the west (Fig. 18), ending in a broken face four inches from the west edge of the unit. At 29 inches below the top of the wal1, there was an irregular surface of 1 arge Timestone rubble and yellow mortar. This surface extended to the south for approximately 24 inches, ending five inches inside the south edge of the unit. The surface extended out of the unit toward the east and stopped four inches inside the west edge of the unit.

From the northeast corner of the mill extending north out of the unit was a less substantial foundation of 7 imestone rubble and yellow mortar. This foundation had a depth of four inches and decreased in width from 16 inches at the wall to 13 inches at the north edge of the unit. There was no evidence of a footing trench. This appears to be the bran room foundation.

Twenty-two inches east of the face of these foundations was a second wall of cut limestone and gray mortar 10 inches wide and 22 inches deep. Between this wall and the mill and bran room foundations was a ditch that had been filled with a series of what appeared to be natural, washed-in deposits. The lower layers ran between the two stone walls, while the upper layers started at the face of the eastern wall and sloped upward over the mill foundation for several inches. This may have been intended as a drainage ditch at some point in the mi17's existence, with the wall to the east serving as a retaining wall.

\section{Unit 8}

Unit 8 was placed on the expected location of the northeast corner of the bran room. It was a 50 -inch-square unit.

Layer 1 was a dark brown to gray crumbly soil with heavy concentrations of rock, gravels, and roots. Brick chips, nails, glass, and contemporary ceramics were mixed throughout the layer. Because of its similarity to Layer 1 in Unit 5, it was considered Tate fill and shoveled out. Following the slope of the upper bank, this layer varied in depth from 14 inches along the east edge of the unit to four inches along the west edge. Layer 2 was three inches of sterile, yellow caliche. Beneath this was compact brown soil identical to that in Layer 5 of Unit 1 . Excavations were continued eight inches into this soil with no structure or disturbance to be found. Extensions to the east and west also revealed no sign of structural remains. 


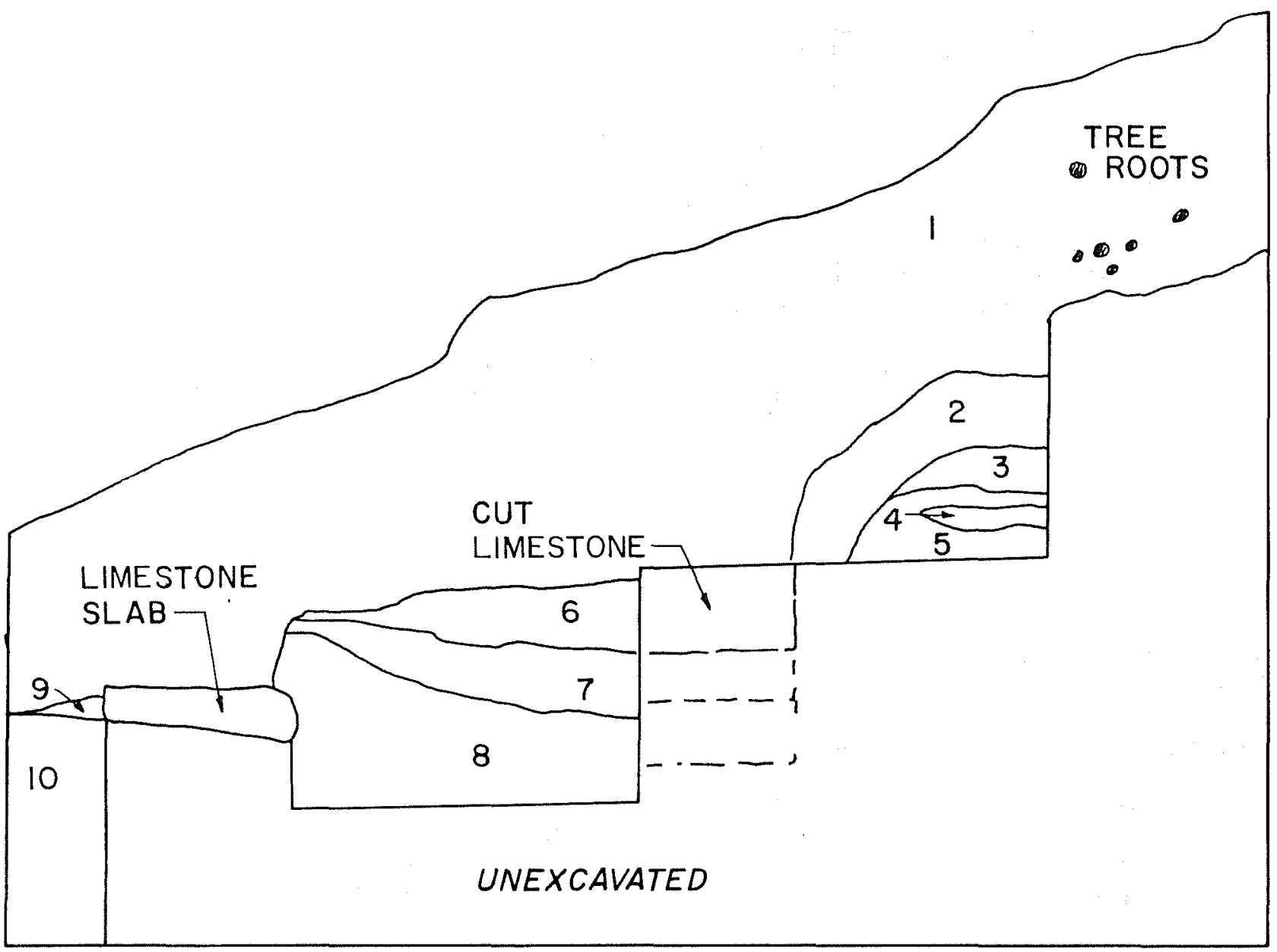

I. MEDIUM BROWN CLAY WITH CHARCOAL, PEBBLES

2. LIGHT CREAM MARL

3. DARK GRAY CALICHE

4. YELLOWISH CALICHE WITH PEBBLES

5. MEDIUM GRAY CALICHE

6. YELLOWISH CALICHE WITH PEBBLES

7. ORANGE BROWN COMPACT CLAY

8. DARK BROWN COMPACT SOIL WITH CHARCOAL

9. YELLOW SANDY MORTAR

10. STERILE TAN COMPACT SOIL

Figure 18. North Wa11 Profile of Unit 7. 
It appeared that the bran room foundations had been completely removed during demolition of the mill, except for a small section next to the northeast corner of the mill.

\section{SEARCH FOR THE RETAINING WALL TO THE SOUTH}

Units 17 and 20 were $\mathrm{placed}$ to test for the stone retaining wall that started at the northeast corner of the mill and ran south before angling to the southeast to the southern boundary of the property at the east end of the old iron bridge (Figs. 7, 8, and 10).

Unit 17 was begun as a 50-inch-square unit. Forty-four inches of fill were removed, but no trace of wall was found. The unit was extended 50 inches to the south and excavated to the same level with no better results. The southern portion was then excavated another 24 inches. One cut stone block was found resting on what may have been an original soil surface at about 68 inches. No other stones were encountered.

Unit 20 was a 50 -inch square that was extended 50 inches to the north. At 42 inches a 7 imestone block was found in yellow caliche beneath a layer of dark, humic soit. The profiles of these units indicated that considerable bank cutting and filling had taken place, probably at the time of the 1926 channelization. Apparently the retaining wall was removed at that time.

\section{WAREHOUSE AND OFFICE INVESTIGATIONS}

A simple, one-story frame building that stood next to Washington Street to the east of the mill was the warehouse and office. We have no information on when it was built, but it was present by 1888 (Fig. 8). This building served as office and warehouse for the Upper Mi17. We have no photographs of it and no information on exact7y when it was moved. It was not there on the 1896 Sanborn insurance map (Fig. 9), when it appears that the warehouse and office building had been moved a slight distance to the north along Washington Street and remodeled into a larger warehouse. This left room for a new office building to the south, as mentioned in Section IV. Since the warehouse was supported above the surface of the ground on what look to be large stone blocks, it seems likely that the original office and warehouse building was similarly supported.

The purpose of the excavations in this area was to determine if any structure remained beneath the surface from the first frame building.

\section{Unit 6}

Unit 6 was a 50 - by 100 -inch unit placed over the estimated location of the northwest corner of the warehouse and office building. A 10 - by 15-inch extension was added at the west corner.

Layer 1 (Fig. 19,a) consisted of 10 inches of compact dark brown clay with lenses of sandy loam. Plaster, fiberglass, large chunks of concrete and 


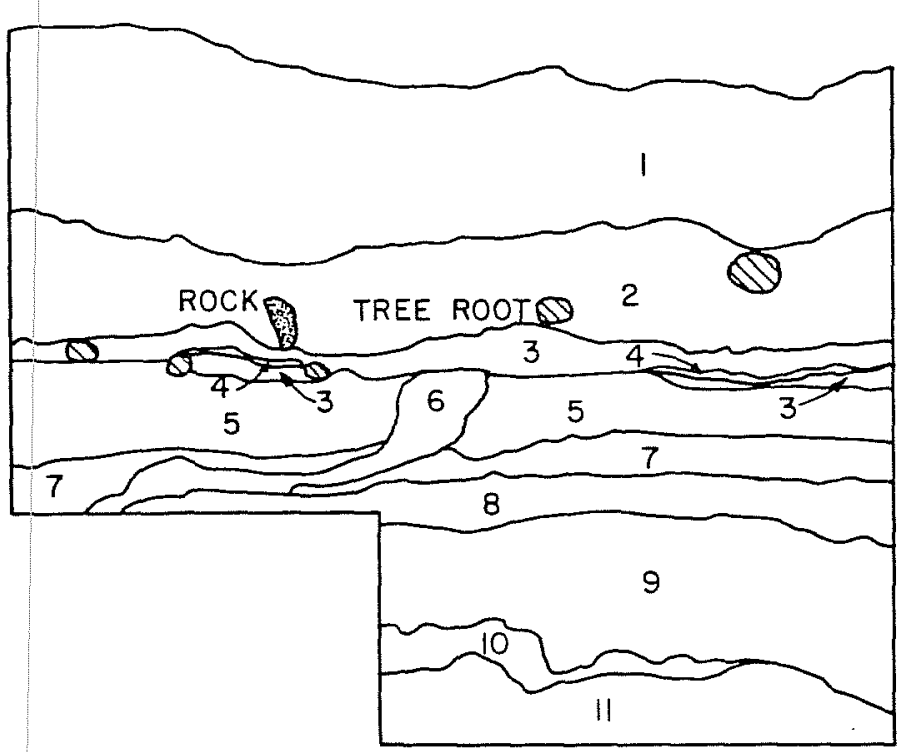

1. COMPACT DARK BROWN CLAY FILL

2. LIGHTER BROWN CLAY FILL WITH PEBBLES

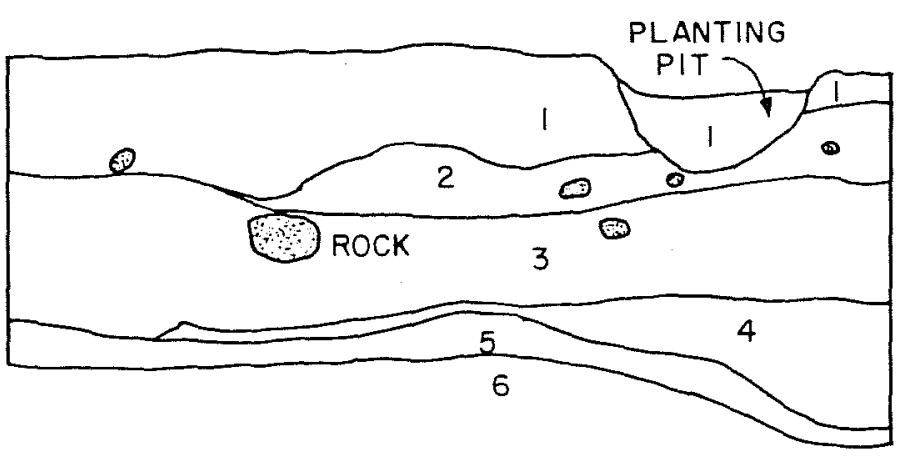

1. DARK BROWN CLAY FILL

2. WHITE CALICHE WITH PEBBLES

3. MEDIUM BROWN LOAM

4. ORANGE BROWN LOAM WITH CHARCOAL AND CINDERS

5. DARK BROWN LOAM

6. GRAY WHITE CALICHE (UNEXCAVATED)

\section{MACARONI FACTORY}

UNIT 22-SOUTH PROFILE

b

\section{WAREHOUSE AND OFFICE}

$$
\text { UNIT 6-EAST PROFILE }
$$

\section{a}

Figure 19. Profiles of Excavation Units 6 and 22. a, east wall of Unit $6 ; b$, south wall of Unit 22. 
limestone, nails, glass, and ceramics were found throughout the layer. Two inches below the surface, extending seven inches into the northwest corner of the unit, an uneven edge of a reinforced concrete slab was found. Layer 2 was a seven-inch deposit of slightly lighter brown clay, containing much the same sort of artifacts.

Layer 3 consisted of one and one-half to three inches of compact yellow brown sandy clay loam. A portion of the soil in the southeast quadrant contained black, greasy patches. Varying from three to six inches thick, Layer 4 consisted of a gray clay, broken in the east half of the unit by patches of tan gray sandy loam with cobbles and compact white caliche. The black greasy soil now formed an irregular-shaped ring with an iron stain along its edge. Extending from under the concrete slab was a cedar post lying in what appeared to be a trench that ran parallel to the north wall of the unit.

Layer 5, a three-inch Tayer of sterile white caliche, was underlain by dark gray clay from one to three inches thick, which also contained no artifacts. Next was five to nine inches of yellow brown clay, below which was an irregular surface of black brown clay. No evidence of a structure was found in this unit, other than the concrete slab and cedar post in the upper levels. It seems probable that Layers 1 and 2 were fill brought in during the later occupation of the site and were contemporary with the concrete slab. Layers 3 and 4 accumulated after ca. 1900, and the caliche in Layer 5 was the original surface of the yard when the mill was in operation.

\section{Unit 9}

Unit 9 was a 50 -inch-square unit placed so that the estimated location of the southeast corner of the warehouse and office building would fall within the center of the unit. Excavation of this unit plus an extension to the east found no indication of structure for the building. However, an extension to the west revealed foundations for the Riegler Creamery ice house (Fig. 11). Discussion of Unit 9 will therefore be discussed next in connection with that structure.

\section{Unit 21}

Unit 21 was a 25 - by 75 -inch unit placed so the most probable location of the southeast corner of the warehouse and office building would fall within it. The topsoil and a layer of gravel were shoveled out. At a depth of eight inches below the surface of the topsoil, the gravel stopped at an uneven surface of gray to brown loamy soil. This varied from one to four inches in depth, and was followed by brown clay, which had a 19-inch-wide strip of gray soil along the east edge of the unit. At midpoint along the west edge of the unit and extending beyond it, was a depression measuring 21 by 32 inches.

The brown clay was removed. It was four inches deep, and below it was tan marl. Sixteen inches from the east wall of the unit two posts were found. A wooden board ran along the outside of the posts. A shallow posthole with a post fragment set in concrete was seen to the southeast of this fence remnant and appears to be part of another, later fence. 
The depression noted earlier was then excavated. It was a 19-inch-deep pit with rounded bottom. The fill had wood splinters throughout. This may be the result of removing a large post.

\section{Unit 23}

Unit 23, a 50-inch-square, was placed on the probable alignment of the north wall of the warehouse and office building. Two inches of topsoil were removed, and a number of intrusions were seen. A 1-1/2-inch metal pipe extended diagonally across the northeast corner of the unit. The pipe was packed in a bed of small gravel. An eight-inch posthole found in the northwest quadrant of the unit extended seven inches into the topsoil. Another eight inches of the fill was removed, several large tree roots were encountered, and further excavation became impractical.

\section{Unit 24}

Unit 24,25 by 50 inches, was placed north of Unit 21 along the east wa71 alignment of the warehouse and office building. The fill was 15 inches deep. When this was removed, the caliche layer was exposed. Penetrating the surface of the caliche were two postholes 36 inches apart, with a wooden board running along their outer edge. This appeared to be a continuation of the fence found in Unit 21. A third post appeared to have been dug through the board fence at a later time.

\section{Unit 25}

Unit 25 measured 25 by 50 inches and was placed on the location of the northeast corner of the warehouse and office building. Eight to 12 inches of fill were removed as Layer 1. Beneath this was an uneven surface of dark brown loam mixed with yellow clay. Along the midline of the unit an 11-inch posthole was found. It penetrated and ended within the medium brown loam of the next layer. No other structural evidence was found.

Apparently little if any evidence remains of the supports for the warehouse and office building when it was in its first position as part of the earlier mill complex. This seems logical if it was supported by the same sort of cut stones as were used to build the mill foundations. These would have been removed, perhaps even just moved slightly north to be used again to support the new warehouse. Such structures were often supported on cedar posts, but there does not seem to be sufficient evidence for such a system here. In any case, there are no structural remains present which would need to be preserved in case of further development on the site.

\section{MACARONI FACTORY INVESTIGATIONS}

When the San Antonio Pasta Works remodeled the mill complex for their own uses about 1902, they connected the existing buildings by constructing a twostory addition between them and in effect rebuilt the first warehouse and 
office building onto the south end of the new warehouse, enlarging it to two stories (Fig. 10). Apparently a covered loading area stood between the warehouse and the river bank, with a five-foot-high stone wall along the top of the bank. One excavation unit was located so as to test for indications of the construction of the connecting building of the macaroni factory.

\section{Unit 22}

Unit 22, 25 by 50 inches, was placed to the east of Unit 9 to test for remains of the south wall of the macaroni factory addition. Seven inches of fill (Fig. 19,b) were shoveled out. Charcoal, broken glass, and limestone fragments were mixed throughout this layer.

Layer 2 was six inches of white caliche with pebbles. A circular pit extended outside the east and south edges of the unit and was nine inches deep. Below the caliche was medium brown loam, designated Layer 3 . This layer was seven inches deep, and at the interface between it and Layer 4 there was a posthole with a wooden board running along its south edge.

Layer 4 was an orange brown soil with rusted iron, charcoal, and cinders. It was one-inch deep except where it filled five inches of a seven-inch-deep depression in the southwest corner of the unit. Below Layer 4 was a white caliche surface, except for a deposit of dark brown loam along the south edge of the unit which also filled the bottom two inches of the depression.

No indication could be recognized in the excavation of Unit 22 as being related to the macaroni factory. It probably was constructed in much the same manner as the frame warehouse and office buildings, and rested on some sort of stone or wooden supports which raised the floor above the surface of the surrounding ground. The circular depression that showed up in Layer 2 was apparently dug to plant a small tree or shrub, probably during the last occupation of the site when it was a residence.

\section{RIEGLER CREAMERY INVESTIGATIONS}

The only modification that the Riegler Creamery made to the area of the plant near the road was to construct a one-story ice house behind the warehouse which tied into the covered loading facilities. Here again, we have no photographs of the buildings.

The intent of the investigations here was to determine what sort of foundations might have been built for the ice house, and how construction methods might have changed since the building of the mill in the late 19th century.

\section{Units $9-15$}

As mentioned previously, Unit 9 started with a 50 -inch-square excavation. Layer 1 (Fig. 20) consisting of three to five inches of fill was shoveled out, as was Layer 2, a five-inch gravel layer. Beneath the gravel was found a 10-inch-wide concrete and stone foundation which ran east-west across the 


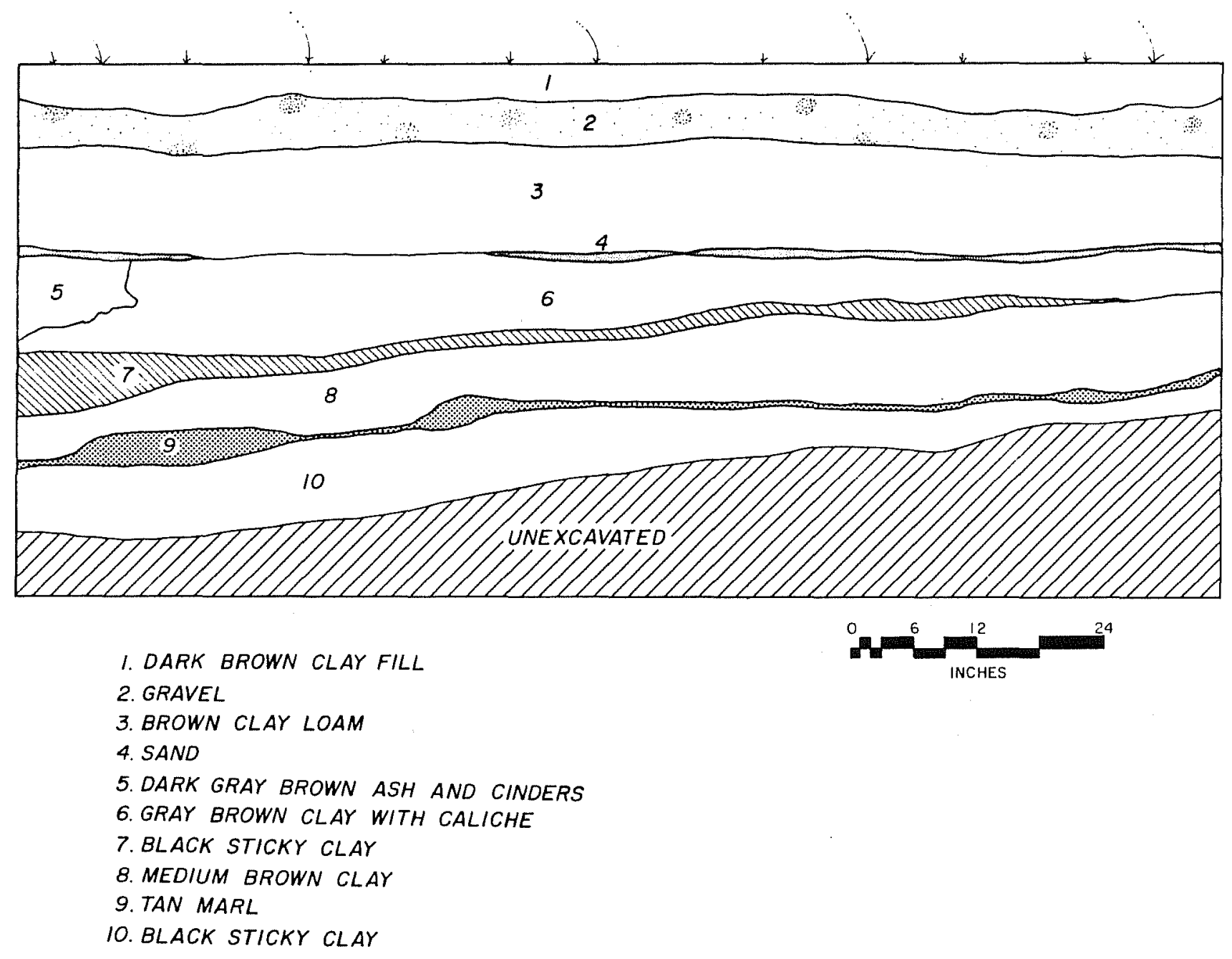

\section{RIEGLER CREAMERY}

Figure 20. North Wall Profile of Unit 9. 
unit. When the unit was extended 70 inches to the west, the wall was found to continue in that direction. A cross wall made a "T" intersection with this wall, and the original wall continued for seven feet four inches beyond this intersection, ending in a finished face. There was a footing trench along either side of the foundation wall, cut into the brown loam that was Layer 3. This layer contained chunks of limestone, glass, wire and cut nails. The foundation sat on a footing of concrete and stone, the bottom of which rested in a gray brown clay (Layer 6). The total depth of the foundation was 20 inches plus five inches of footing.

Layer 4, beneath the brown loam, was a 1/2-inch-thick layer of sand. Below this was Layer 5, a dark gray brown gritty ash and cinder deposit along the east wall, varying from five inches at the north edge to eight inches at the south.

Layer 6 consisted of gray brown clay with patches of caliche. It contained a number of pipes in shallow trenches, a cedar post, and two different "deadman" bolts for the utility pole which stood near the sidewalk in this area. The layer averaged four inches thick and contained fragments of wood, glass, mortar, and nails. Layer 7, a black sticky clay, sloped downward from north to south. Layer 8 was a medium brown clay sloping east to west, over a thin layer of tan marl. Below this was a black clay layer. Dug from the interface of the latter two layers was a line of postholes with wooden boards attached along their south side.

Units 10 and 11 were 25-inch-square units placed to check for remains of the interior foundations of the ice house as revealed in the west extension of Unit 9. Excavation was limited to clearing off the fill to trace the top of the wa11, which was at 13 inches in Unit 10 and at 10 inches in Unit 11 below the present surface. The foundation here was 12 inches wide.

Unit 12 was a 60 -inch-square unit placed over the north wall of the ice house. The north foundation was found to be 21 inches below the surface, and varied from 13 to 18 inches in width. The foundation wall was nine inches deep, resting in a marl similar to that found in Unit 9 at a shallower level.

Units 13, 14, and 15 were units of various sizes placed so as to trace out the west wall of the ice house foundation. Several large surface tree roots prevented the examination of the southwest corner; however, the rest of the foundation was found to be approximately 12 inches below the surface in that area. Unit 15 encountered a concrete slab immediately below the surface, probably part of the Goldstein House missed by the demolition crew.

Evidently the foundation of the ice house from the Riegler Creamery is still intact about a foot below the surface. While this was hardly a historic building, it was an integral part of the history of the mill site and probably should be avoided, or at least considered, when future plans are made for development of the site. 


\section{THE STRIBLING HOUSE INVESTIGATIONS}

The Stribling House was described in 1865 as being made of stone (San Antonio Herald 1865). The 1885 Sanborn insurance map (Fig. 7) shows it as having wooden structures along the east and west faces, probably porches. By 1912 (Fig. 11) the western addition had been infilled with brick nogging. Available photographs unfortunately show only small portions of the south side of the house behind the mill buildings (see Figs. 6 and 8 ). The house appeared in later photographs of the mill to be slowly deteriorating, and apparently it was razed when the mill was dismantled in 1926.

Although the Stribling House was never in any way connected to the mill operation, it was located on property directly adjacent to the mill and will be affected by any proposed development of the mill property in the future. It was therefore decided to locate and examine briefly the state of preservation of the foundations of the house in order to make recommendations for future treatment of the area. Three excavation units were needed for this purpose.

\section{Unit 16}

Unit 16 was a 50-inch-square (Fig. 21) unit placed on the estimated location of the southeast corner of the house (Fig. 14). The soil in Layer 1 was three inches of sandy $10 \mathrm{am}$ and contained wire nails. Layer 2 was a light tan sandy deposit that looked like disintegrated mortar or rough plaster. It contained a yellow brick and several limestone fragments. This layer averaged about five inches thick. Below this was a layer of dark brown sticky clay, varying from three inches at the north end of the unit to 12 inches at the south end. Layer 4 was composed of reddish tan sandy soil containing numerous fragments of broken limestone, yellow bricks, and broken cement fragments. The top of the remains of the foundation wall of the Stribling House was found to be approximately five inches below the top of Layer 4, or 21 inches below the ground surface.

\section{Unit 19}

Unit 19 was a 50 -inch-square unit (Fig. 21) placed over the south wall of the front porch of the house (Fig. 14). The unit was extended to connect with Unit 16 and to locate the southeast corner of the stone portion of the main house. In Layer 1, the soil to the south or outside the building was dark brown clay with no artifacts. Soil to the north was the same light tan sandy loam found in Unit 16, only with cut nails. This same differentiation in soil color and texture continued until the top of the wall was encountered beneath a layer of rubble at $\mathrm{ca} .20$ inches. The porch wall foundation was found to butt against the house foundation, and fragments of flagstone were found against the porch foundation. 


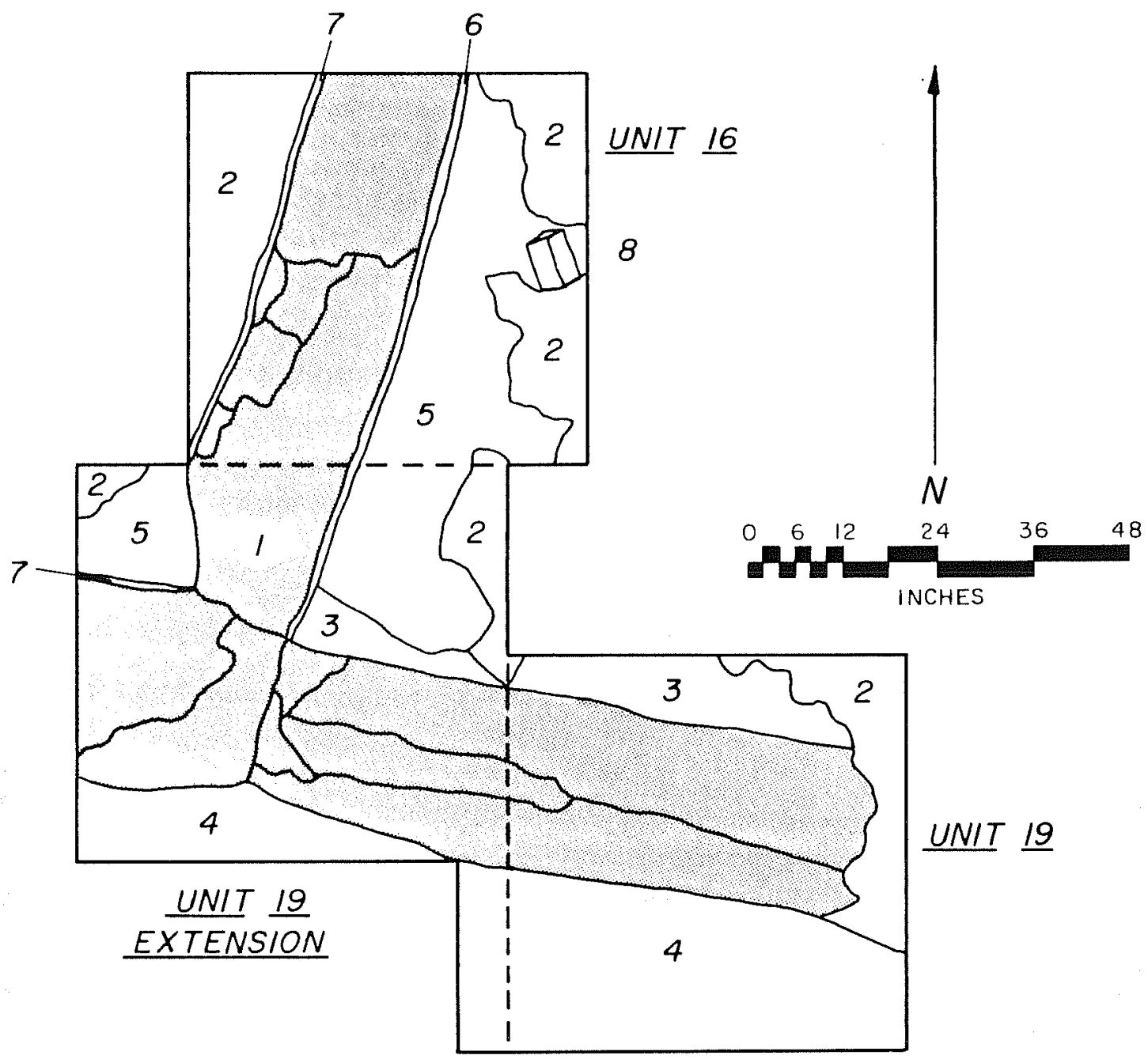

1. LIMESTONE WALLS

2. LOOSE ROCKS

3. FLAGSTONE

4. DARK BROWN CLAYEY SOIL

5. LIGHT TAN SANDY SOIL

6. STUCCO FACING

7. PLASTER

8. YELLOW BRICK

Figure 21. Plan of Stribling House Excavations, Units 16 and 19. 
Unit 18 was originally a 50-inch-square unit that was expanded to the north and east by a 75-inch addition (Fig. 14). It was placed over the location of the southwest corner of the central stone house. The same two types of soil were found in this unit divided more or less by the wall line as projected from Unit 19. Numerous fragments of broken 1 imestone and occasional red and tan brick fragments were found throughout the deposits. The foundation, found at 18 inches below the surface, had a coating of stucco one-inch thick on the south side.

It appears that the layer of dark brown fill also overlies this portion of the terrace, which tends to confirm the speculation that it was placed there when the property was landscaped during the Goldsteins' occupation, in order to level out the area and cover the remains of the previous building foundations. The presence of numerous bricks of several colors confirms the use of brick as nogging in the back walls of the Stribling House.

The stone center section of the house was found to be 21 feet wide. The walls were constructed of irregular cut limestone with sand and lime mortar. The walls were 18. inches wide, and the outer surfaces were faced with stucco, while the interior surfaces were plastered. At the southwest corner, the remaining wall is 22 inches deep below which is a 12-inch-deep limestone footing.

\section{REMOVAL OF THE MILL REMAINS}

The next phase of field work at the site of Guenther's Upper Mill involved clearing and documenting the mill remains within the river channel. The remains were a stone wall parallel to the bank, about 15 feet out in the channel; the wooden floor of the wheel pit; a wooden upright member next to the bank; the north wall of the forebay; and the stone wall which formed the partition between the forebay and the wheel pit. Complete and detailed documentation of these features was not possible during the first phase of the field work because the area was generally under water and was covered by a layer of random cut stone resulting from the 1926 demolition of the mill structure. Since all of the remaining traces of the mill that were in the channel would have to be removed during channelization, it was essential that careful documentation be done. Exposing, documenting, and removing these structures required 16 field days and an archaeological crew of two to eight persons, as well as a construction crew of six members. The following rather detailed description of the process is included for the use of anyone who undertakes a similar operation in the future.

\section{Clearing the Forebay/Wheel Pit}

The construction of the new lining of the river channel south of the mill had been in progress for several months, and the river in that area had already been diverted to the west half of the riverbed. The corrugated steel diversion dam from that section was extended north connecting with one located east to west, north of the mill, effectively isolating the mill from 
the narrowed river channel. Standing water was then removed by electric pumps. This process took three days, at which point the site was dry enough to work.

The construction company built an access road on the lower terrace north of the mill for use by heavy equipment in removing the stone and timbers. During this road-building operation, a six-foot-wide portion of the mill's north wall was accidentally destroyed by a bulldozer.

An area on the upper terrace was set aside as a long-term storage site for the salvaged cut stone that was not to be relaid on the site and wooden mill timbers that would need to be dried out gradually to avoid warping and splitting.

The contract required all cut stone lying within a specified distance of the mill to be salvaged. This stone was salvaged throughout the field work phase as it was exposed by preparations for channelization. Stones too far from the mill vicinity to be reached with a crane were removed by backhoe onto a flatbed truck and hauled to the upper terrace storage area.

Two days were required to remove the random cut stone piled in the forebay/wheel pit area. The stones were lifted one at a time, cradled in a nylon sling which was attached to a crane, from the mill to the upper terrace. Two workers from the construction company positioned the stone so that the sling could be passed around its midpoint. The sling was tightened, fastened to the crane, and lifted to the upper terrace. A worker in the storage area guided the stone to the ground and unfastened the sling, and the crane carried the sling back to the mill site. It took approximately five minutes to remove each stone.

Once the construction crew had removed the stones and heavier debris, the archaeological crew joined them in the forebay/wheel pit to clean off the accumulation of mud and gravel from the floor of the structure. All of this cleaning was done manually to avoid damage to the wood and stone members present. The archaeological crew and construction workers then cleaned out the tailrace area to the south. Once this area had also been thoroughly cleaned, documentation of the integral parts of the mill could begin.

\section{Recording}

The 15- by 30 -foot section of the mill in the riverbed that had been 1 ittered with random cut stones and river debris was now clean, and construction details were visible for recording (Fig. 22,a,b). A low stone wall two feet thick divided the interior into two chambers, the forebay to the north and the wheel pit to the south. Three courses of stone survived in this wall. Only a few stones of the top course were still in place, and several in the next course were out of alignment.

The bottom of the wheel pit was covered by a wooden plank floor (Fig. 23) that was one inch higher along its north edge than on its south edge and had a slight slope to the west. Examination of the floor showed each beam to be composed of several planks fastened together. This floor guided the water 


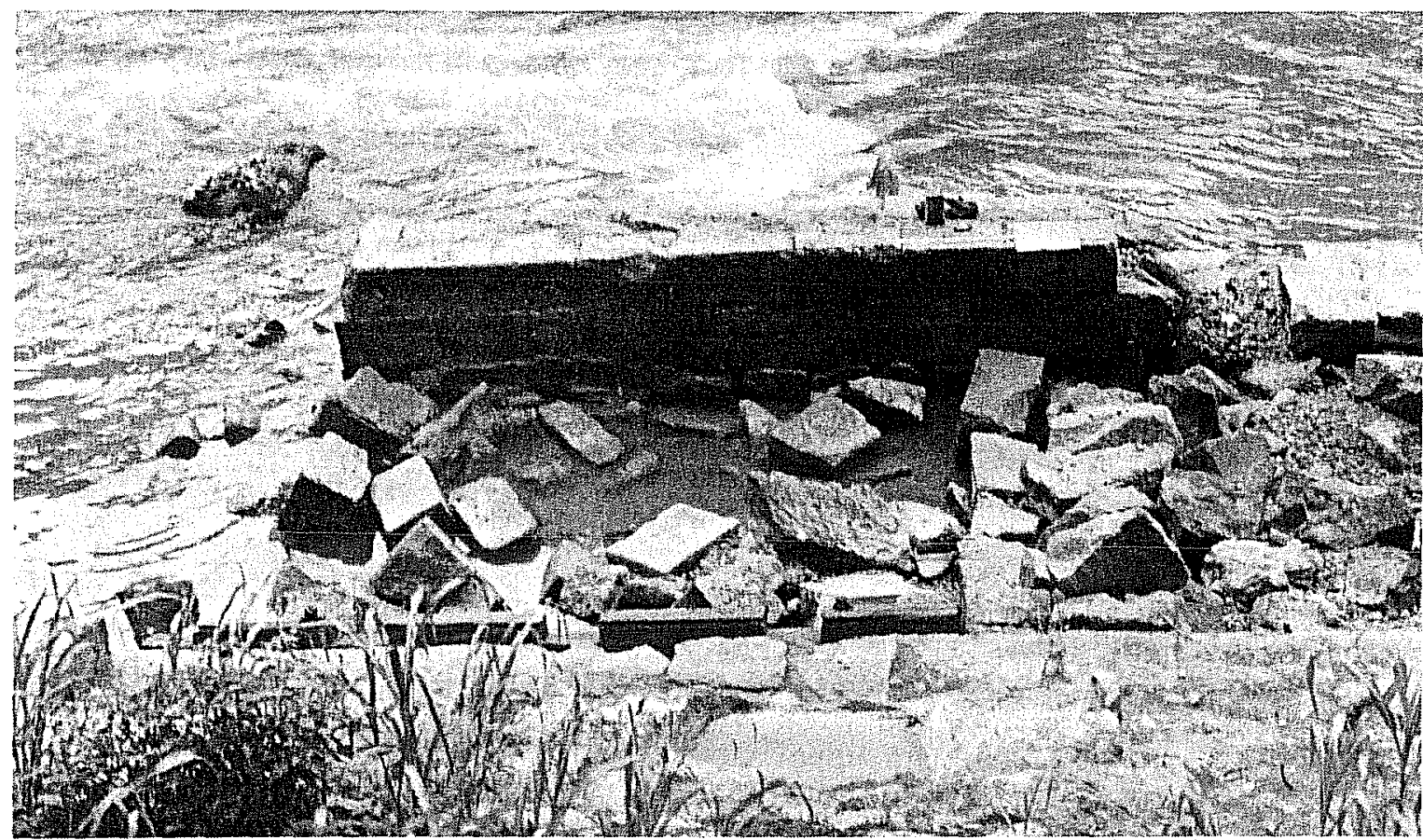

a

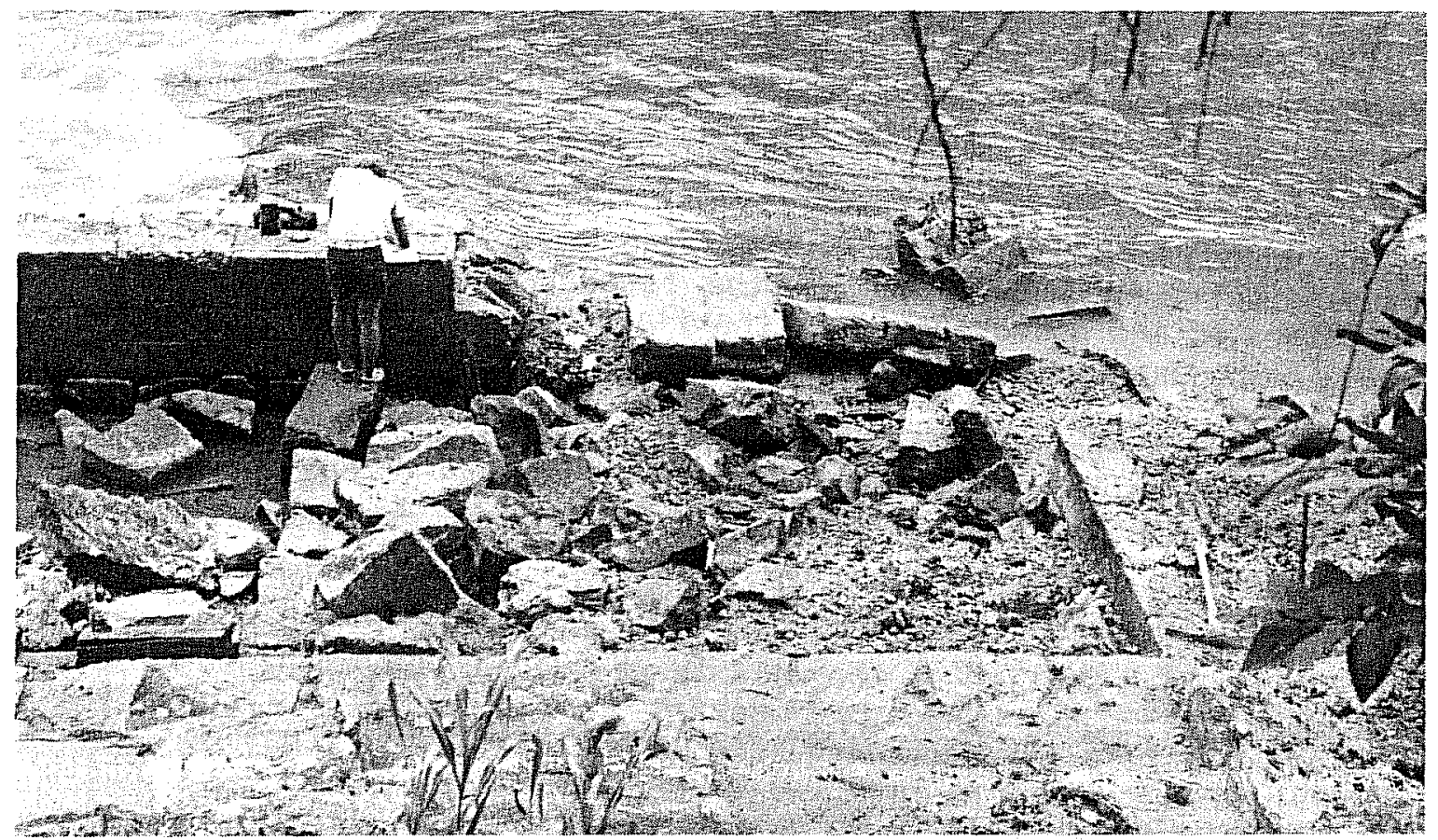

b

Figure 22. Wheel Pit and Forebay Before Clearing, Looking West. $a$, south end; b, north end. 


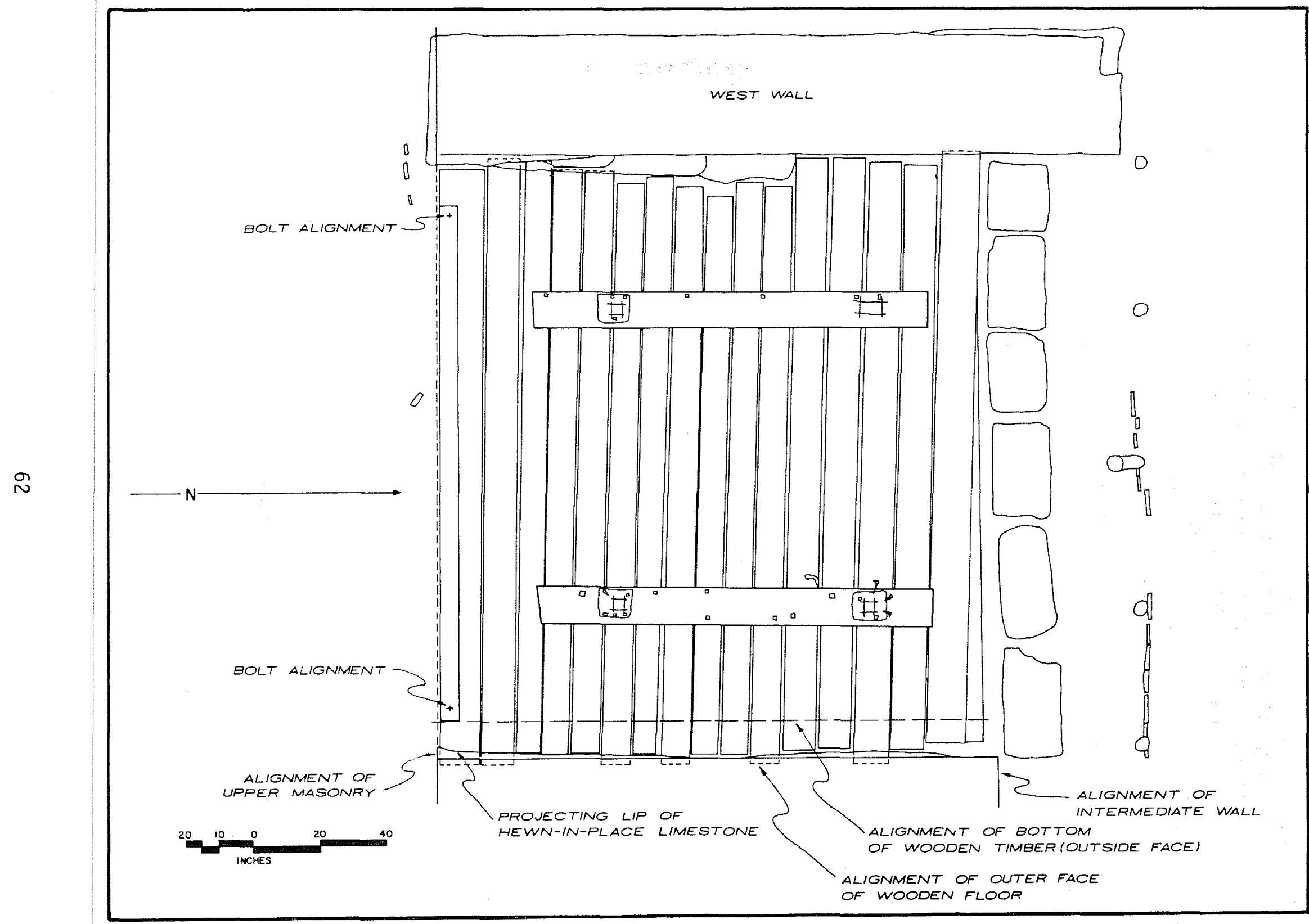

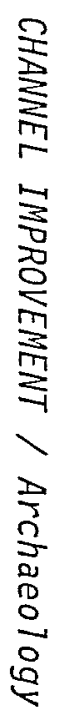

Figure 23. Plan of Wheel Pit Timbers. 
out from the wheel and kept the river bottom beneath the wheel from being eaten away by the force of the water. Against the east wall of the wheel pit and tilted slightly away from it at the top was a heavy cypress upright member. This was constructed of four horizontal beams joined by an iron rod running through them at either end (Fig. 24,a). The upright was not attached to the floor, but was recessed two inches under the lower edge of the east wall of the wheel pit. Two wooden beams ran north and south on the surface of the wheel pit floor. They were attached with cut nails to the flooring and had notches cut into them, apparently for the framing that supported the turbine. The southern edge of the wheel pit floor was faced with a beam that also recessed two inches under the eastern wall of the wheel pit.

The north mill foundation extended west to become the north wall of the forebay. The riverbed surface appeared to form the floor of the forebay. A series of cedar posts supporting cedar planks was located north of the partition wall dividing the forebay from the wheel pit. The tops of the posts were sheared off, but traces of notches survived in the tops of several (Fig. $24, \mathrm{~b})$.

The top of the west wall stood at about the same elevation as that of the east wall for the forebay/wheel pit. The west wall crossed the natural dam of caliche in the river, and this was reflected in the way it was constructed. The wall, built of cut stone, was three feet wide. The outer faces of the stones were dressed, but the inner faces were irregular. The spaces between them were filled with random-sized chunks of limestone and very hard sandy lime mortar. In the northern half of the wall, the two lowest courses of stone were fitted to the contour of the dam, and some of the stones were irregular in shape. Several of these stones projected from the foundation at odd angles. The west wall was carefully recorded by photographs and measured drawings in preparation for its removal and later replacement (Fig. 25, a, b).

\section{Removal}

The north wall of the forebay was the first wall to be dismantled. Since there was no plan to reconstruct this wall, the stones were not given individual numbers; an orange circle was painted in the upper right hand corner of the south side of each stone to identify it as coming from the north wall. The stones were lifted individually by sling and crane to the storage area.

The forebay/wheel pit dividing wall was removed in a similar manner, the stones being marked with a square in the upper right hand corner of the south face. Once the upper courses of the wall had been removed, it was decided to leave the lower course in place temporarily to protect the wooden floor of the wheel pit until it could be dismantled and removed. These were taken up after the wheel pit was cleaned out. The documentation and removal of the two walls took two days.

The wooden floor, except during documentation, was kept wet and covered with plastic until it was time to remove it. The wooden upright structure against the east wall of the forebay/wheel pit had been exposed to natural wetting 

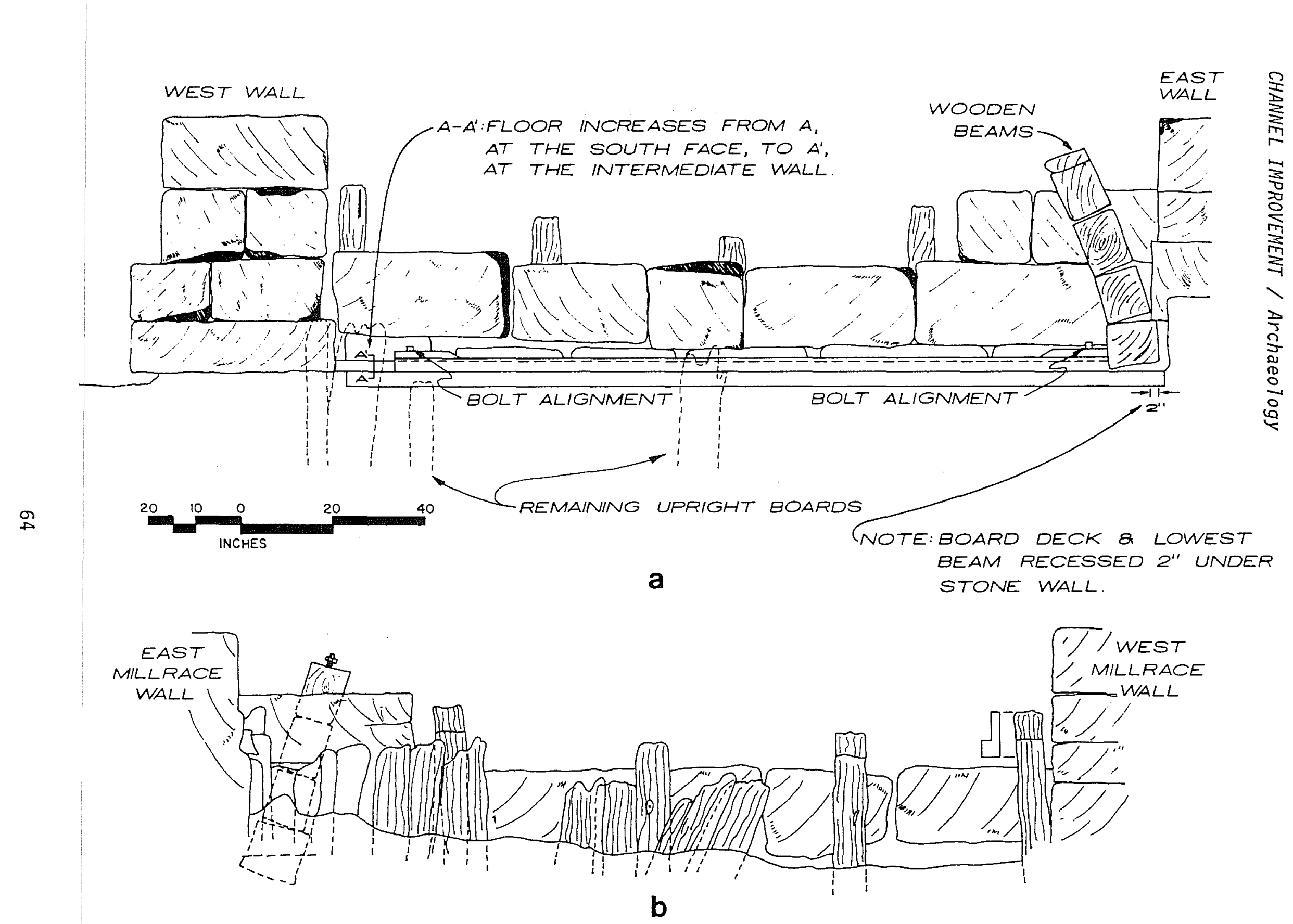

Figure 24. Cross Sections. a, through wheel pit, looking north; b, through forebay looking south. 


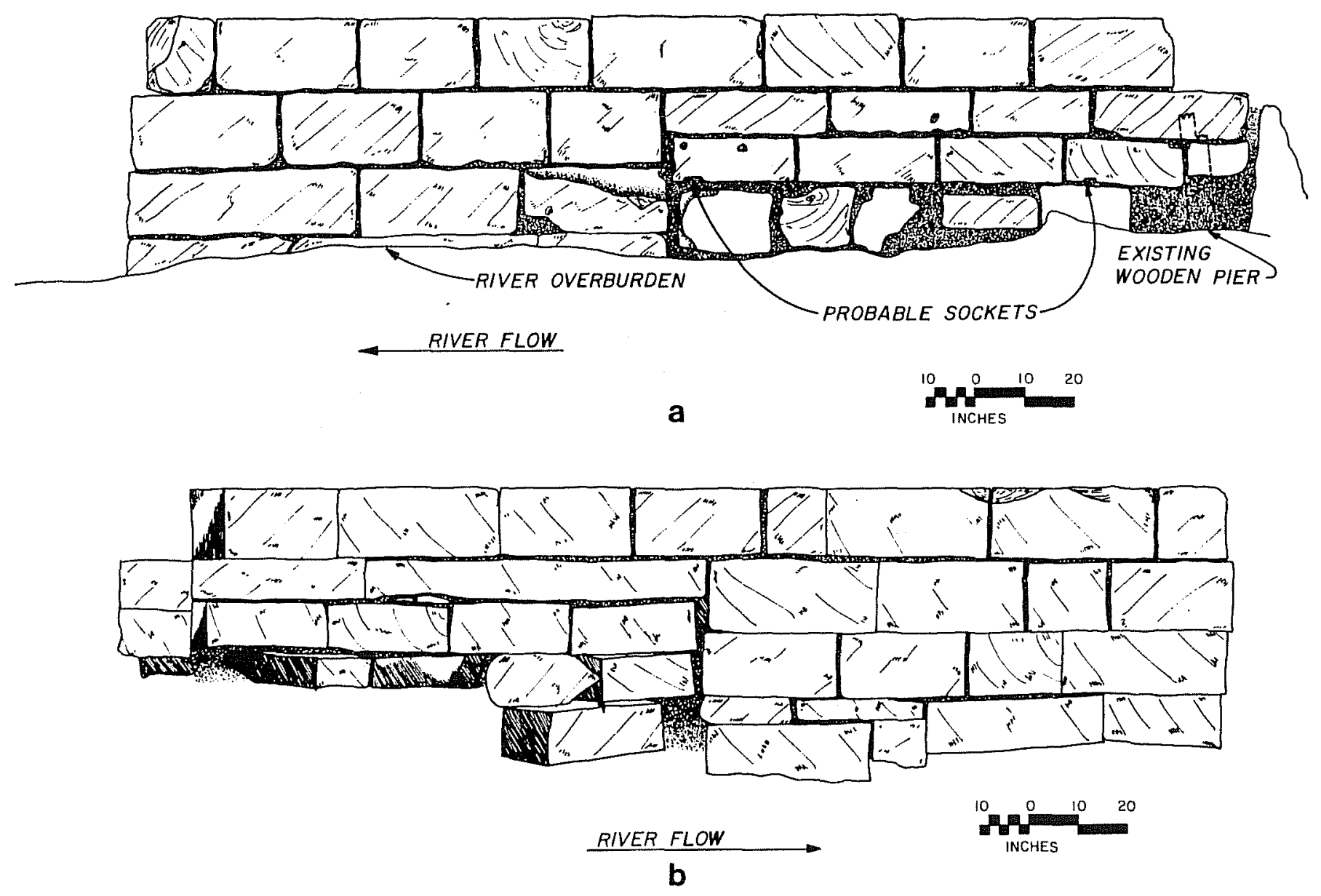

Figure 25. Record Drawings of West Wal1. a, looking west; b, looking east. 
and drying for several decades, and no additional measures were taken to protect it.

The four beams that made up the upright wooden structure were joined by metal rods passing through them. It was not known if these rods would break from the stress of being moved, or if they were attached to the wheel pit floor. An attempt to dismantle it by removing the top beam with sling and crane showed that the structure tended to hold together and to move as a unit. It was then pried loose at the bottom and lifted with the sling to a temporary resting place at the top of the lower terrace north of the mill.

An on-site method of preserving the wooden materials from the mill was necessary because of the large size and heavy weight of the timbers. Prior to the removal of the wooden floor, a drying pit had been constructed on the upper terrace, between the foundation of the Stribling House and the terrace edge. The pit measured 6 by 17 feet and was four feet deep, and the bottom was covered with 12 inches of sand. The sand was thoroughly wetted with water containing fungicide before the first timbers were placed in it.

The wooden pieces attached north-south to the floor of the wheel pit were removed first. It was found that the best method for 1 ifting the boards was to put two slings around several boards at a time and 1 ift them slowly, allowing the boards to adjust and stack themselves within the slings as they were raised from the ground (Fig. 26,a,b). At the storage area, all debris was scraped and was hosed from the surface of the boards, and they were sprayed with fungicide as they were lowered into the pit. An eight-inchlayer of sand wetted with fungicide was placed between each of the three layers of wooden members. The wooden upright structure was lifted to the storage area and placed on top of the floor timbers. Some samples of the posts and fence boards from the feature in the forebay were also placed in the pit. The drying pit was then completely filled with sand wetted with fungicide, and a low wooden crib was built around the edge at ground surface to keep the sand from being washed away. The documentation and removal of the wooden materials took two days.

Detailed documentation of the west mill wall was done in measured drawings indicating the description and location of each stone (Fig. 25), and photographs were taken from all directions to aid in its later reconstruction after the channelization was completed. The upper right hand corner of the exposed face of each stone in the wall was given a coded identification number, applied with a black magic marker. The code number indicated course, stone number, and wall face, referring to the measured drawings.

Two stonemasons, aided by members of the construction crew, dismantled the wal1. Wire brushes were used to clean the surfaces of the stones. The stones were separated with a variety of tools: metal hammers, flat chisels, brick splits, plug-ins, wooden wedges, an electric Roto Hammer, and a flat blade saw (Fig. 27,a,b). It was obvious that the masons who built the original mill foundation had used an excellent mortar mix (see 01 iver Evans' instructions in Section III), for the mortar was, if anything, harder than the limestones set into it. However, thanks to the skill of the masons, the stones were removed in excellent condition. Wooden planks and a crowbar were used to position the stones to receive the slings for lifting (Fig. $27, c$ ). 


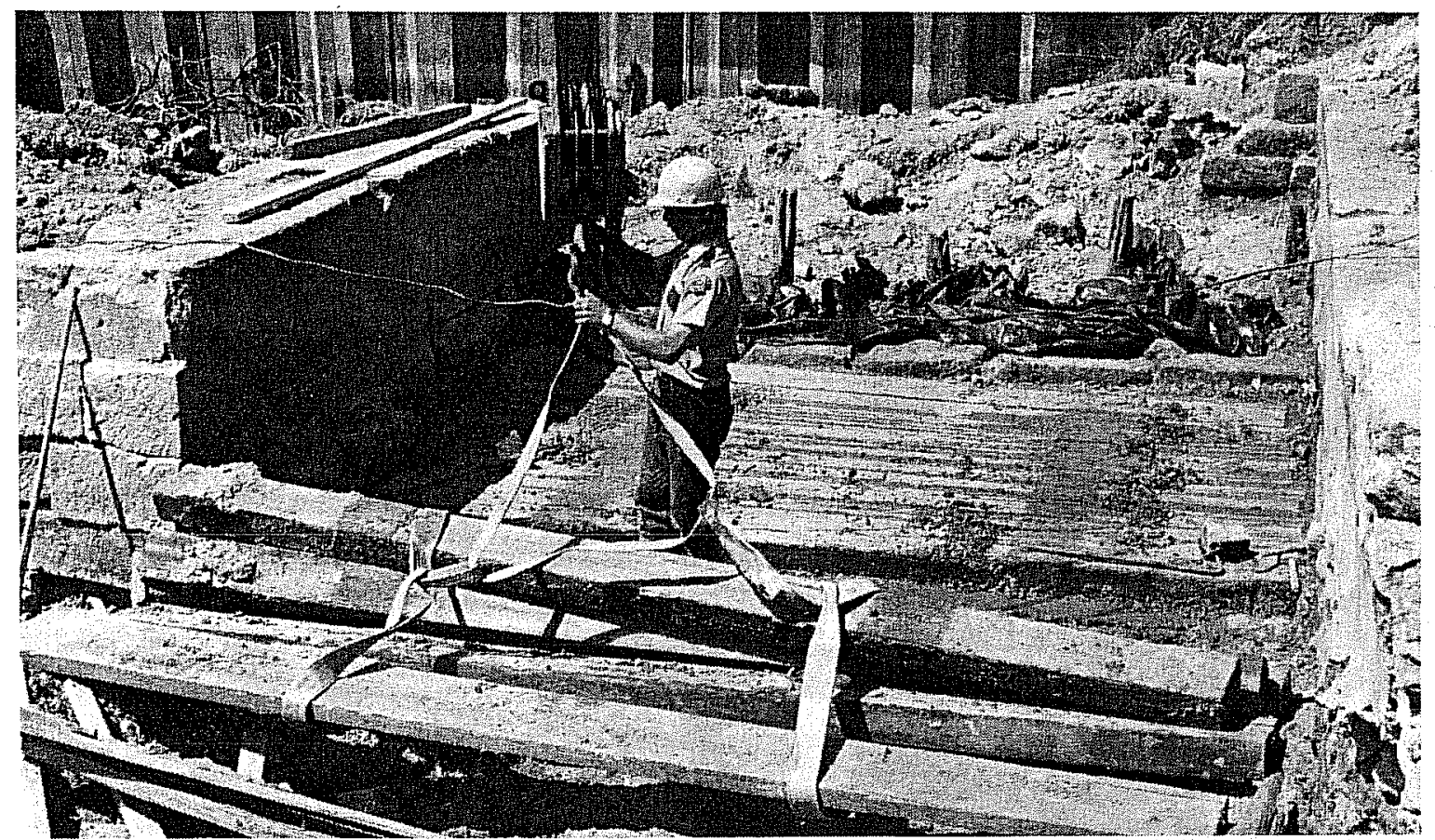

a

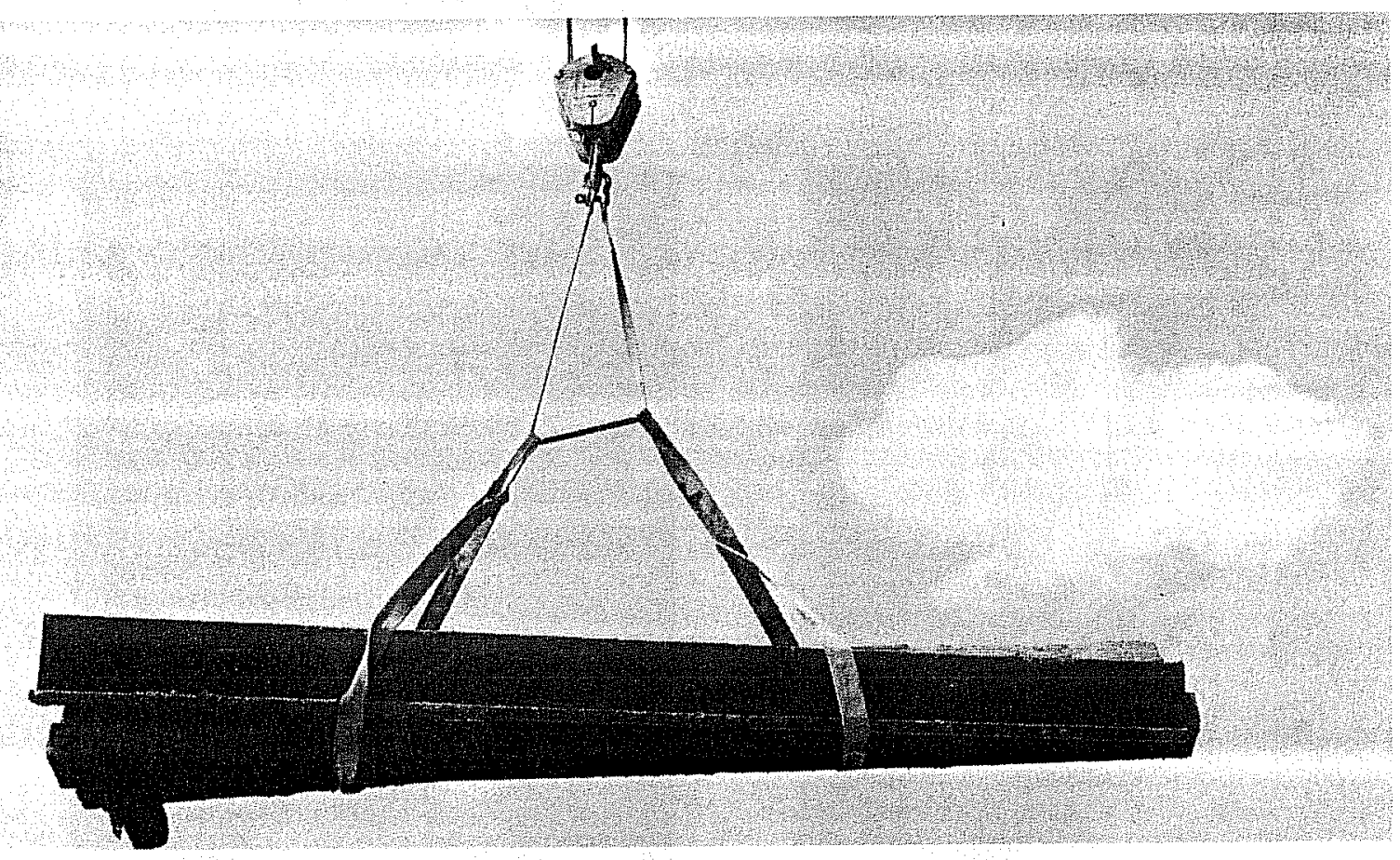

b

Figure 26. Removal of Wheel Pit Timbers. a, attaching slings; b, hoisting with crane. 


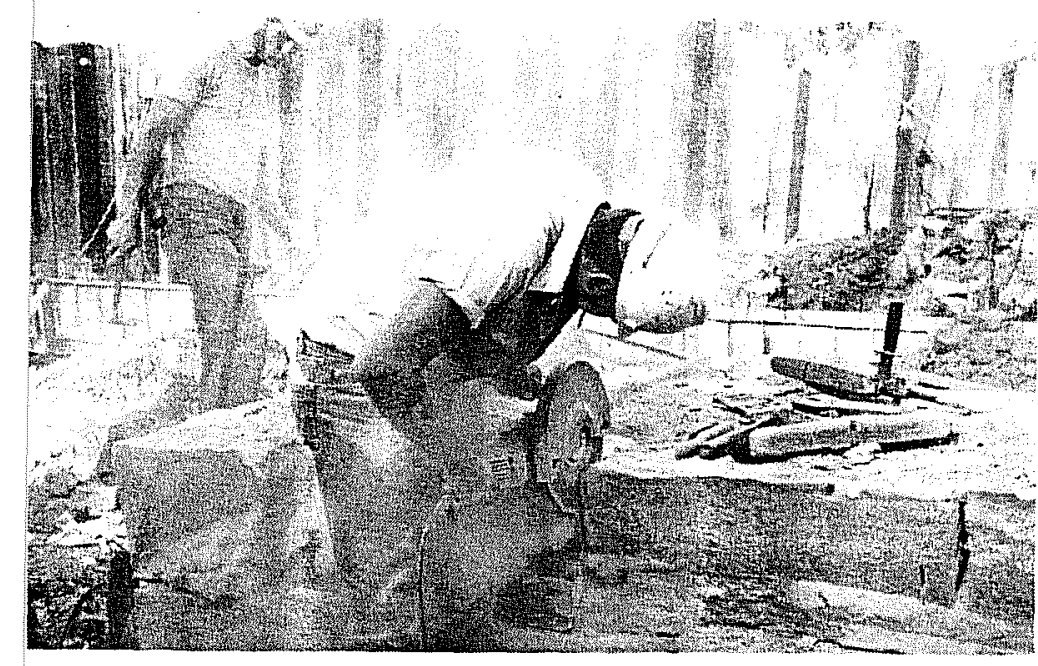

a

(9)

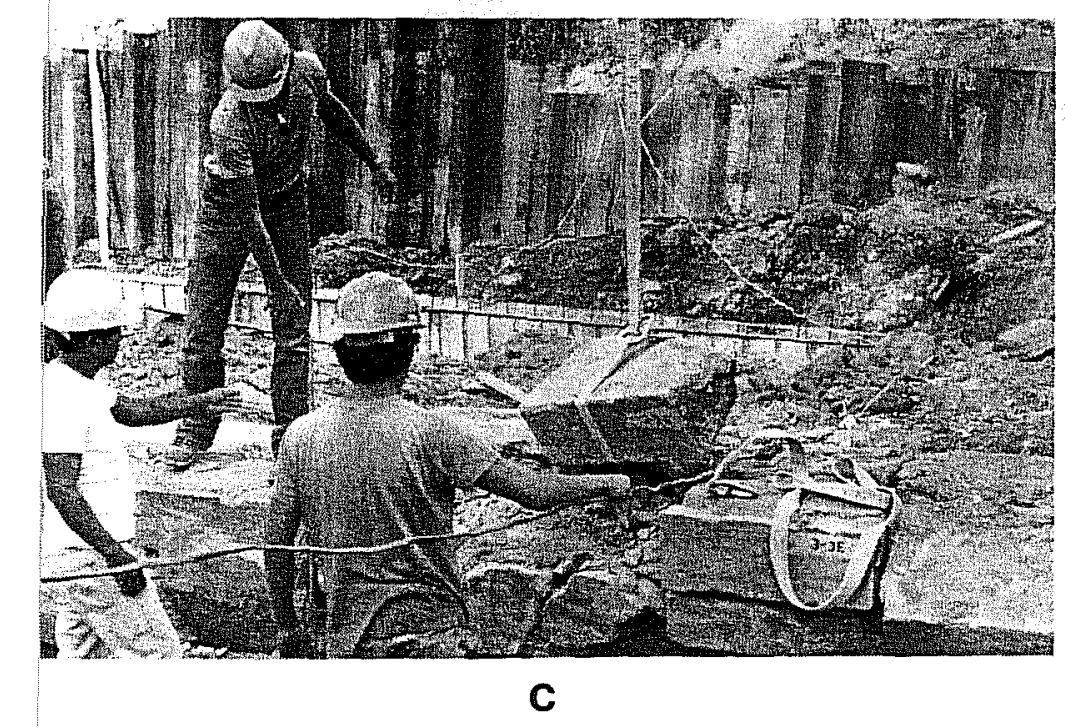

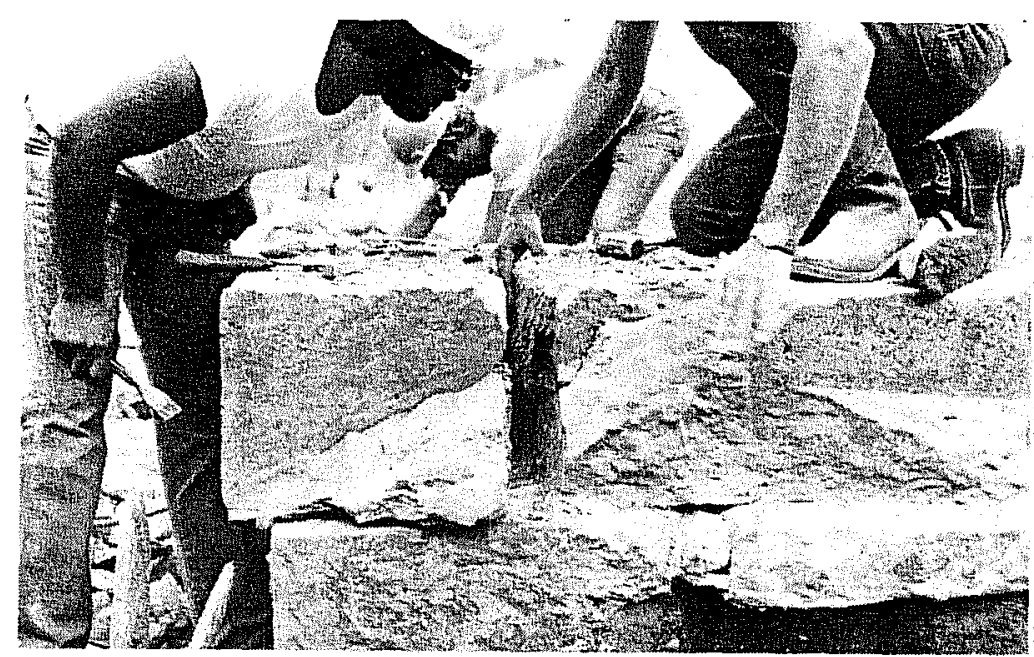

b

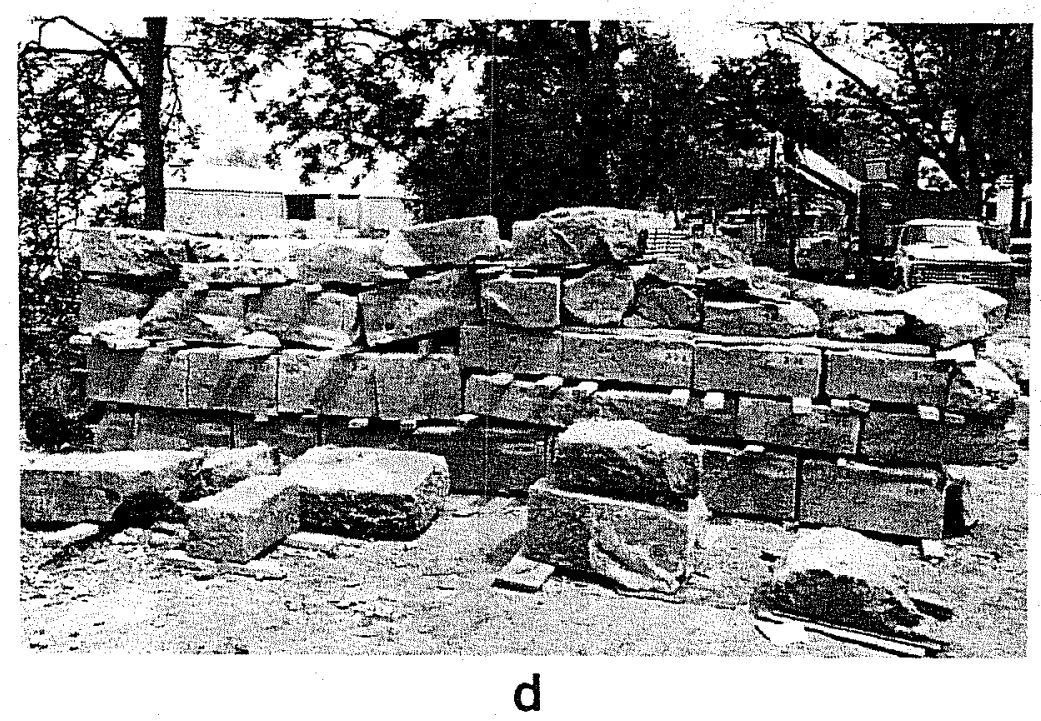

Figure 27. Removing West Wall. a, cutting mortar joints; b, loosening stone; c, attaching sling; d, temporary storage on top of bank. 
After the first course of stone was separated, the stones were lifted individually and placed in a set order on the upper terrace south of the long-term storage area. Each additional course was stacked on the previous one, the stones being separated by boards to avoid damaging them (Fig. 27,d). When the wall had been removed, the locations of the stones on the terrace were recorded and the numbers checked to be sure they would all be identifiable when the time came to reconstruct the wa11. The documentation and removal of the west wall took approximately two days.

The masons then trimmed the stones in the north wall to be flush with the stones in the east wall of the forebay/wheel pit. This was done in preparation for the construction of the planned retaining wall tying the mill into the new wall of the river channel.

The remaining stones of the partition wall across the forebay/wheel pit were marked in black wax crayon in the center of a painted orange square, numbered consecutively from west to east. They were removed from the water still standing in the forebay, measured, and lifted to the upper bank. This procedure took one-half of a day.

\section{RECONSTRUCTION OF THE WEST WALL}

The final phase of the field work consisted of monitoring and documenting the reconstruction of the west wall in the new river channel. Prior to the beginning of this effort, a 32-inch-high concrete foundation for the wall was constructed on the original location of the wall as determined by the measured drawings (Fig. 28,a). The decision was made to raise this wall slightly higher than its original elevation to allow for the construction of the foundation, and to assure sufficient stability for possible reconstruction of the mill building at a later time. The mill foundations in the bank had also been reinforced by the addition of a concrete retaining wall for several feet into the bank along the north and south sides.

The masons erected a metal and wood scaffolding around the concrete base (Fig. 28,b). The base was wire-brushed, and a level string line was established. The base was slightly narrower than the bottom course of the original wall, and the newly reconstructed wall would overhang it two inches on the east side and four inches on the west.

Using the nylon sling, each stone was lowered in sequence from the storage site to the scaffold by crane. The stone was cleaned with stiff brushes to remove old mortar, then set in place, using the detailed drawings and photographs of the original wall as a guide (Fig. 28,c,d).

The bottom course of the wall had originally been fitted to the surface of the natural fall in the river. In order to keep the proper coursing, several stones salvaged from elsewhere in the mill were substituted for the natural formation. As the wall was reconstructed, stones selected from the pile of salvaged cut stone were used to make chinkers and levelers.

The reconstruction of the west wall took seven days. Three full-time and two part-time masons were needed in addition to the crane operator. The masons 


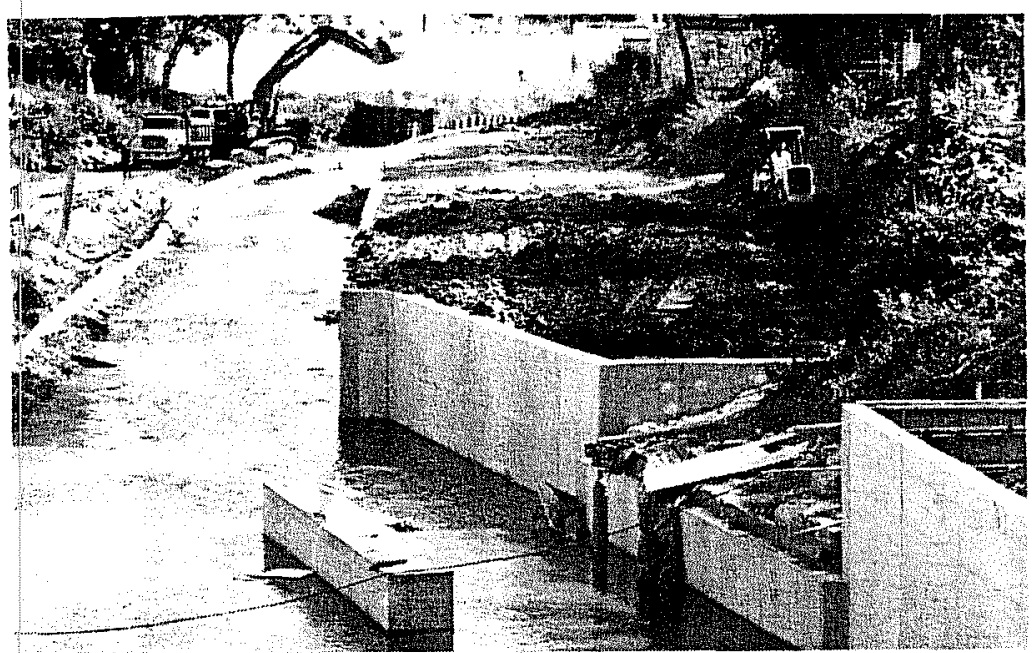

a

כै

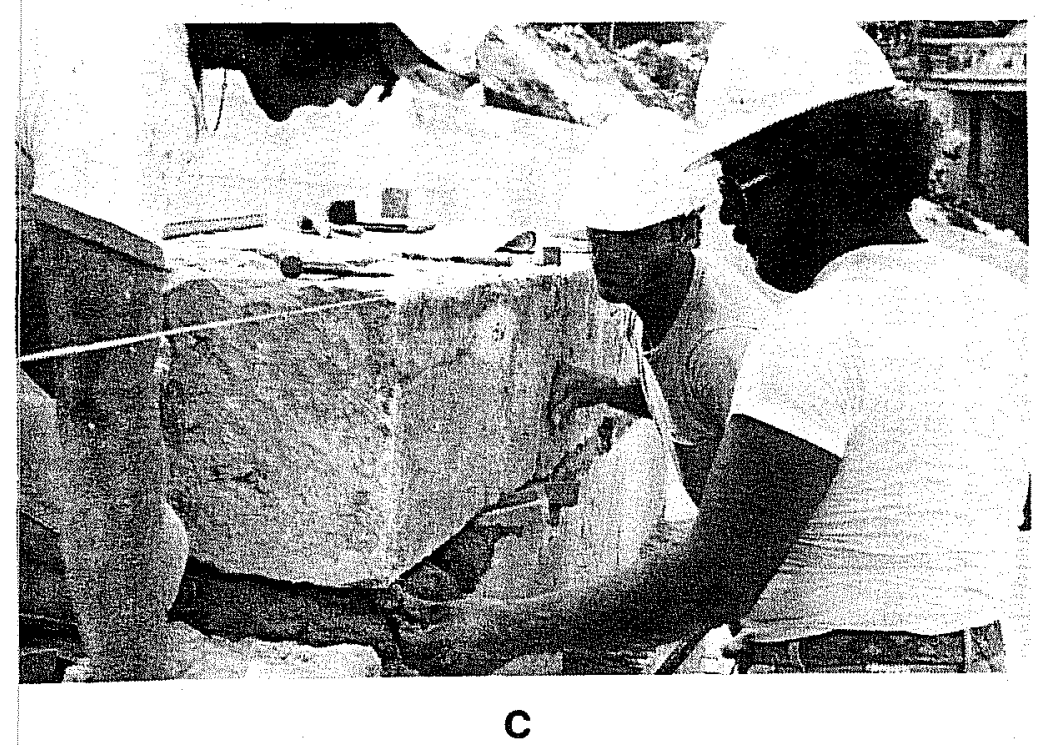

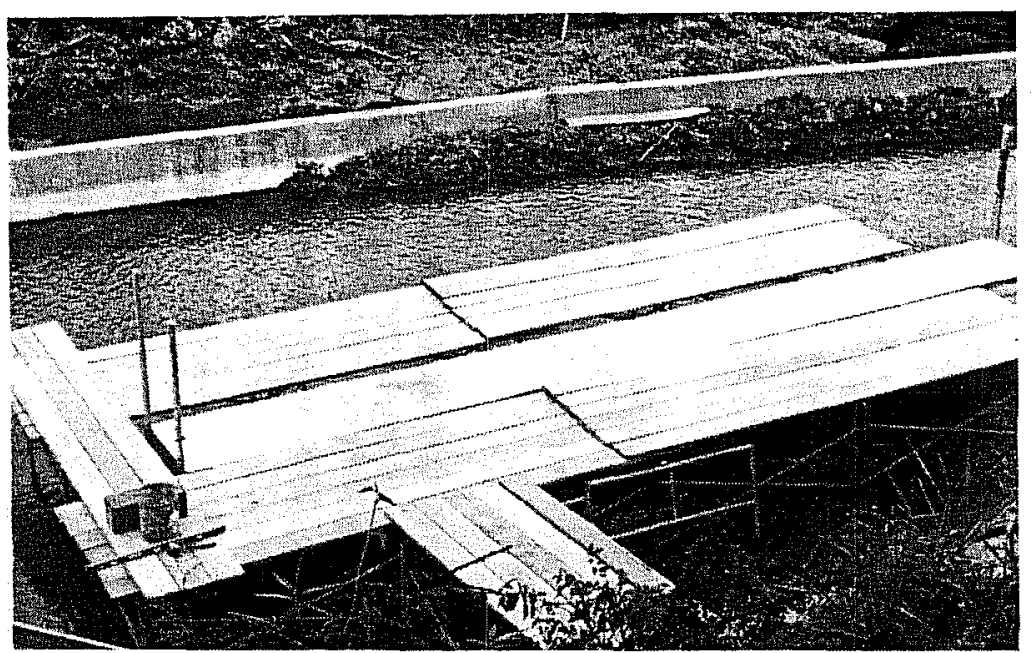

b

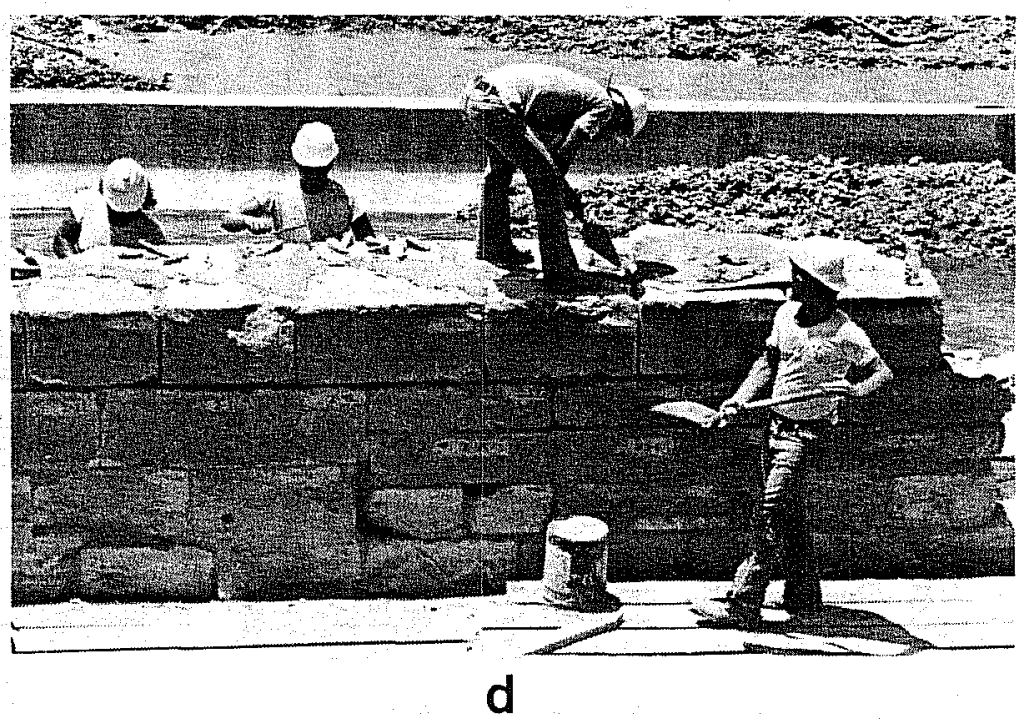

Figure 28. Reconstruction of West Wall. a, concrete footing; b, working platform in place; c, setting individual stones; d, finishing wall. 
also reset several loose stones at the south end of the east wall of the wheel pit, trimmed and reset stones left in place at the joint of the north and east walls of the forebay, and replaced the section of the north wall that had been damaged during preparation for stone and timber removal.

All remaining salvaged cut stone was lifted to the storage area, and a security fence was erected around it. The King William Historical Society agreed to assume the responsibility of monitoring the slow drying out of the timbers and the maintenance of the stored stones. 


\section{SUMMARY AND CONCLUSIONS}

A total of 25 units was excavated at carefully chosen locations over the mi11 site, in order to determine what structural elements remain beneath the surface. The entire foundation of the mill was located, and its condition and construction were examined. The remains of the decking in the wheel pit were recorded and removed, as were a number of other wooden structural members. The west wa17, which had survived the demolition of the mill in 1926 and numerous floods since that time, was recorded, removed, and then restored in the new concrete-7ined channel.

Investigation of the locations of buildings related to the mill tended to confirm the visible impression gained from early photographs that these buildings sat on cut stone supports rather than solid foundations. One later (ca. 1910) building, the ice house for the Riegler Creamery, had a cemented stone foundation, of which at least a part still remains below ground. The stone foundations of the Stribling House were found to be intact at about 20 inches below the present surface.

\section{THE MILL STRUCTURE}

Completion of this project involved many techniques common to historical archaeology, including search of archives and deed records, historical and technical research, consultation with experts in various fields, field survey and testing, and archaeological excavations. In the process, the authors assimilated a great deal of information on 19th-century mills and milling, which was then related to the structures found during the investigations. After examining the remaining structural elements of the mill and the historic photographs, it has been possible to make a tentative reconstruction of operations in the forebay/wheet pit area.

The reconstruction necessary to install the turbine would have eliminated most of the original structure in the wheel pit that supported the water whee1. However, traces of the water wheel operation remained in the opening in the west wall (Figs. 6 and 12) that supported one end of the horizontal shaft, and traces were found on the east wall of the wheel pit in Area B of the location of the gearing that transferred power to the vertical spindle. The wooden head gate and trash rack outside the west wall of the forebay (Fig. 6) remained in service throughout the time that the turbine was used for power. The wooden posts that stood just north of the stone wall separating forebay and wheel pit may have been part of the support for a flume that directed the water to the wheel (Fig. 3). This would have been dismantled when the turbine penstock was constructed, or it could have been converted to use in that construction.

The two parallel wooden beams that ran north-south at either side of the wooden floor of the wheel pit supported the frame of the penstock that controlled the flow of water to the turbine (Fig. 23). The timber structure that stood against the east wall of the wheel pit was probably also a part of the turbine installation, to judge from the position of the notches in its upper edge. Photographs of the mill after the turbine was installed show the 
massive timbers used in the frame for the penstock. These outlived the use of the turbine and apparently were not removed until the demolition in 1926 .

Returning to 01 iver Evans' (1832) instructions for building a mill, it would at first appear that Guenther followed them carefully. Since Guenther received his milling education in Germany ca. 1840 (Schuchard 1951:1) and might not at that time have had reference to Evans' work, it seems possible that Evans compiled all the best milling information then available to him, and that both Guenther and Evans drew from the same pool of basic milling technology.

In any case, we have found that Guenther was a careful builder and followed the basic precepts of good mill construction. He carefully controlled the flow of water to the mill through the headgate and the flood control gate in the dam. He chose the most efficient type of wheel for the circumstances of the mill, an undershot wheel. We found evidence that he built the wooden parts of the mill of large, heavy timbers to withstand the vibration and strain of the machinery. The mill foundations were made of large, we11shaped stones, set in the proper mortar, which did indeed "turn to the consistency of stone" as Evans advised.

Since we have none of the upper portion of the mill to examine, this is about as far as we can go in reconstructing the inner workings of the Upper Mill, other than the lists of equipment published on the Sanborn insurance maps. The 1885 and 1888 maps list the following equipment (for definitions see Glossary):
On the first floor:
On the second floor:
2 run of stone
3 flour \& 1 meal
1 meal bolting reel
bolting reels
1 hopper
1 Eureka smutter
1 Victor mill
1 purifier

This is a pretty standard inventory for a mill set up to grind for a custom trade. The Sanborn insurance map done in 1895 shows a transition to a roller mi17, probably by this time completely changed over to commercial grinding:
On the first floor:
1 double set Grays rolls
1 branduster
1 separator
1 stone braken hominy mill
1 Eureka smut machine

On the second floor:

1 centrifugal reel

1 Smith purifier

1 bolting chest

2 corn meal bolts

1 Cyclone dust collector

1 hominy and grits purifier

We can read about such machines and what their purpose was and estimate approximately how they were arranged within the mill, but nothing of them remains today as a tangible part of the mill. 
However, a fortuitous find has given us one last glimpse of the milling operation that, like the timbers and the foundation stones, can be examined and appreciated for what it says about the rugged construction and the aweinspiring power of the mill in operation. When the construction crew excavated the river channel to the southwest of the mill site, they found a circular iron band and a number of very heavy, oddly shaped stones. These were immediately recognized by the archaeologists as pieces of a French burr stone. Careful examination of the stones dredged from that area turned up all but one section of the original stone (Fig. 29,a,b). The stone probably was discarded in the river after the conversion of the mill to rollers. It was not mentioned in the newspaper article on the demolition in 1926, at which time it would probably have been saved, for sentimental reasons if for no other. The millstone is identical to a burr stone that once stood on display next to the gate at the Lower Mi11 (Schuchard 1951:41).

\section{GUENTHER, THE RIVER, AND THE TOWN}

Carl Guenther arrived in San Antonio when the flow of water from the springs was still heavy and dependable, when the population was comparatively low, and water use was minimal. He saw the gradual decrease in the river's flow brought about by the very increase in population that assured him success in his business, and he was flexible enough to change with the times. First he built a second mill; then he enlarged and modernized the first mill to meet the rising demand for flour. As waterpower continued to wane, he changed to steam power, always using the newest equipment and stressing the quality of his product.

From the time that Guenther built his first mill, his operation was a major industry in San Antonio. It did not take him long to assess the local situation and realize that commercial milling would better meet the needs of this community, where there was relatively little subsistence farming. When competition became strong, he renovated his mills and shrewdly anticipated the coming need for new forms of power. Thus, he was able to endure and outlast his competitors.

Guenther's mills and their milldams and ponds were an integral part of the San Antonio River and of the community. For many years they endured the major floods, due to C. H. Guenther's knowledge of mill construction. When it was finally decided that the dams were detrimental to the rapid evacuation of flood waters from the town, Guenther had already converted to other forms of power and no longer depended upon them. It is interesting that the west wall of the Upper Mill was not completely removed when the milldam was dynamited and the mill razed in 1926. No doubt this was a tribute to the strength of construction of the mill foundation, that required electric saws to finally dismantle it during this project. 


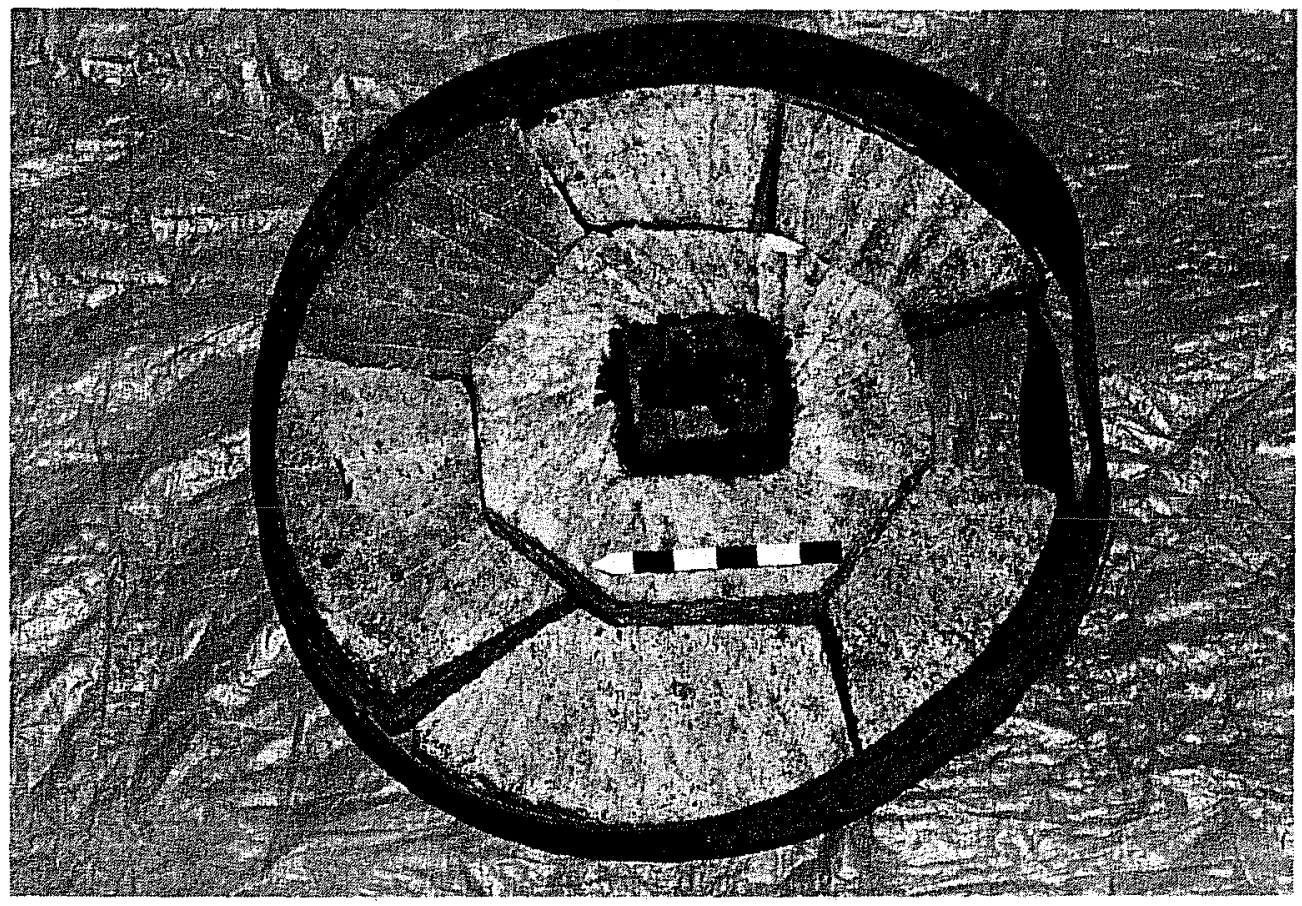

a

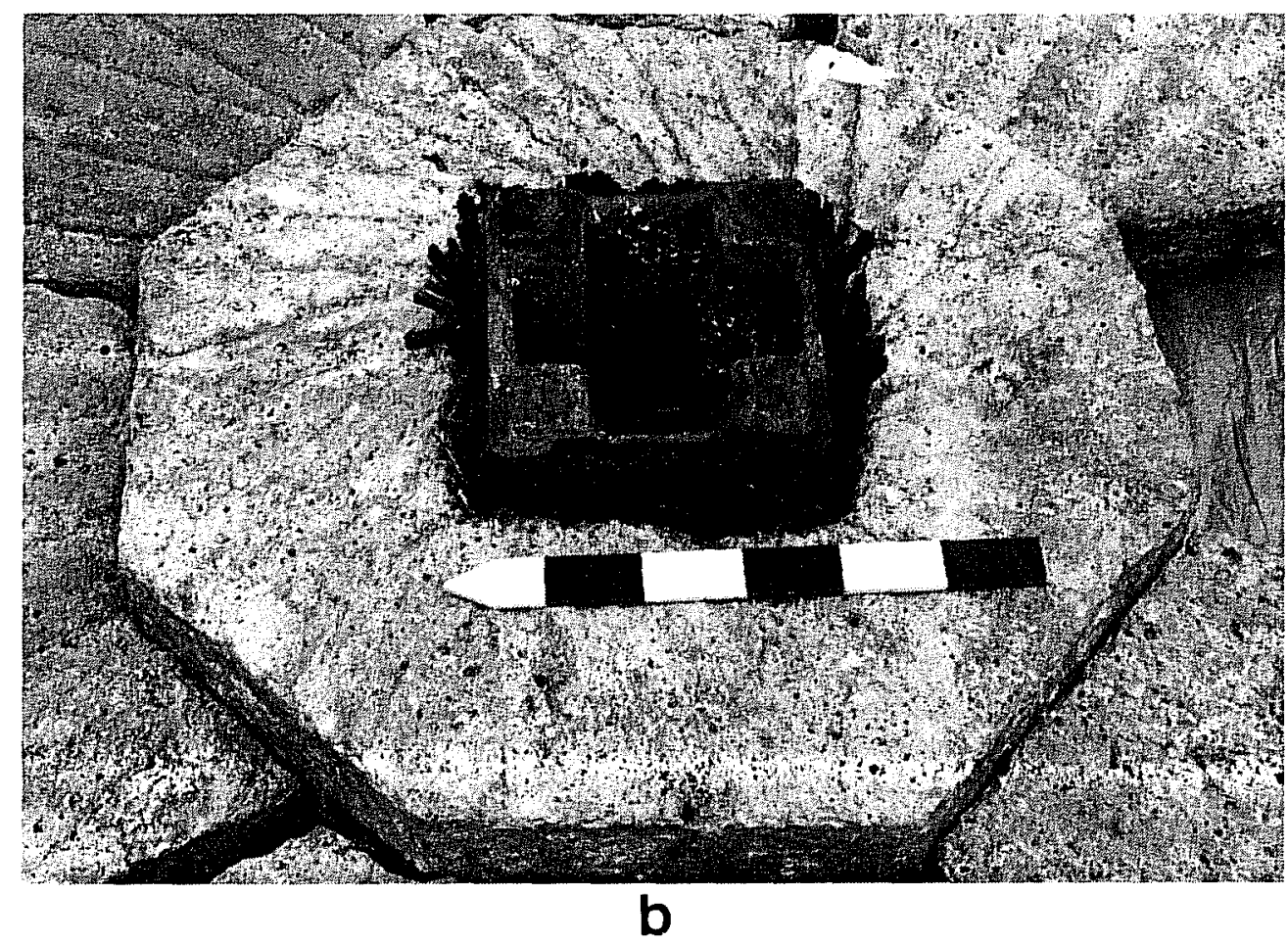

Figure 29. Millstone. a, French burr stone recovered during dredging of the river; $b$, central section showing metal portion that attached to the drive shaft, indicating that this was the runner, or upper, stone. 


\section{RECOMMENDATIONS}

Guenther's Upper Mill site, as mentioned in the Introduction, is protected as a cultural resource by its inclusion in the King William Historic District. Since the property belongs to the City of San Antonio, we recommend that it also be nominated as a State Archeological Landmark. We further strongly recommend that any future landscaping and possible reconstruction work planned for the site be done in consultation with a qualified professional archaeologist. 


\section{GLOSSARY}

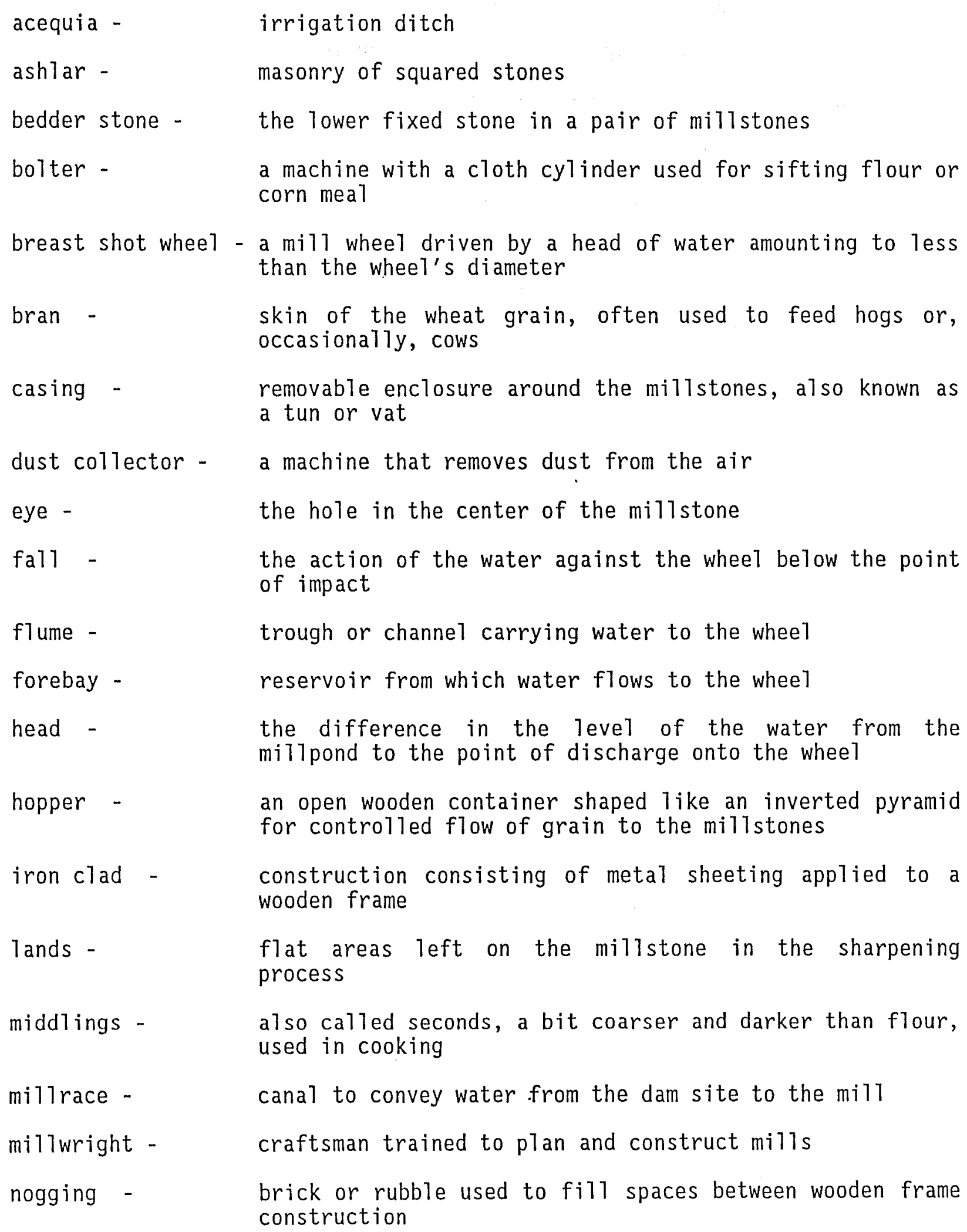

breast shot wheel - a mill wheel driven by a head of water amounting to less than the wheel's diameter

bran - skin of the wheat grain, often used to feed hogs or, occasionally, cows

casing - removable enclosure around the millstones, also known as a tun or vat

dust collector - a machine that removes dust from the air

eye -

the hole in the center of the millstone

fall -

the action of the water against the wheel below the point of impact

flume -

trough or channel carrying water to the wheel

forebay reservoir from which water flows to the wheel

head -

the difference in the level of the water from the millpond to the point of discharge onto the wheet

hopper -

an open wooden container shaped like an inverted pyramid for controlled flow of grain to the millstones

iron clad -

construction consisting of metal sheeting applied to a wooden frame

lands -

flat areas left on the millstone in the sharpening process

middlings -

also called seconds, a bit coarser and darker than flour, used in cooking

millrace -

canal to convey water from the dam site to the mill

millwright craftsman trained to $\mathrm{p} 7 \mathrm{an}$ and construct mills

nogging -

brick or rubble used to fill spaces between wooden frame construction 


$\begin{array}{ll}\text { penstock - } & \begin{array}{l}\text { trough or pipe carrying water to the wheel, or a sluice } \\ \text { gate controlling the flow }\end{array} \\ \text { rich mortar - } & \text { mortar made with a high proportion of quicklime or cement } \\ \text { runner stone - } & \text { the upper revolving stone in a pair of millstones } \\ \text { shaft - } & \text { transfers the power from the water wheel to the gears } \\ \text { shoe - } & \begin{array}{l}\text { tapering wooden trough discharging grain from the hopper } \\ \text { into the eye of the runner stone }\end{array} \\ \text { shorts - } & \begin{array}{l}\text { lowgrade flour containing germ and fine bran, generally } \\ \text { used for animal feed }\end{array} \\ \text { smutter - } & \begin{array}{l}\text { a machine that cleaned the wheat before grinding } \\ \text { spindle - }\end{array} \\ \text { stone and supports the runner stone } \\ \text { suerte - }\end{array}$




\section{REFERENCES CITED}

Amos, P. A.

1912 Processes of Flour Manufacture. Longmans, Green, and Co., New York.

Appler, J. A.

1903- General Directory of the City of San Antonio, 1903-1904. San 1904 Antonio.

Beckmann, W. N.

1951 Carl Hilmar Guenther and the Story of the Pioneer Flour Mills. In 100th Anniversary, Pioneer Flour Mi11s, 1851-1951, compiled by Ernst Schuchard. Naylor Publishing Company, San Antonio.

Bexar County, Texas

Bexar County Deed Records (BCDR)

Originals and microfilm in the Bexar County Courthouse, San Antonio, Texas.

Spanish Archives

Originals in the Bexar County Courthouse, San Antonio, Texas.

Burkholder, M. V.

1973 The King William Area: A History and Guide to the Houses. The King William Association, San Antonio.

Chabot, F. C.

1937 With the Makers of San Antonio. Artes Graficas, San Antonio, Texas.

City Directories

1881-1882 San Antonio, Texas. On microfilm at the Center for Archaeo$1887-1888$ logical Research, The University of Texas at San Antonio.

$1892-1893$

$1895-1896$

Corner, W.

1890 San Antonio de Bexar: A Guide and History. Bainbridge \& Corner, San Antonio. 
Cruse, $k$.

1985 History of the Yturri-Edmunds House and Mi11, 257 Yellowstone, San Antonio, Texas. Manuscript on file at San Antonio Conservation Society.

Department of the Army, Corps of Engineers, Fort Worth District

1969 Flood Plain Information, Salado Creek, San Antonio, Texas. october.

1980 San Antonio Channel Cultural Resource Investigations.

Durrenberger, E. P.

1965 Anderson's Mi11 (41 TX 130): A Historic Site in Travis County, Texas. Bulletin of the Texas Archeological Society 36:1-70.

Evans, 0.

1832 The Young Mill-Wright and Miller's Guide; Illustrated by Twenty-eight Descriptive Plates. 7th edition. Carey \& Lea, Philadelphia.

1972 The Young Mill-Wright and Miller's Guide. Arno Press, New York.

Everett, D. E.

1975 San Antonio, The Flavor of Its Past, 1845-1898. Trinity University Press, San Antonio, Texas.

Farris, F. B.

1985 From Rattlesnakes to Road Agents, Rough Times on the Frio. Texas Christian University Press, Chisholm Trail Series 3. Fort Worth.

Fox, A. A.

1986 Archaeological Investigations at the United States Arsenal Site (41 BX 622), San Antonio, Texas. Center for Archaeological Research, The University of Texas at San Antonio, Archaeological Survey Report 137.

Gerstle, A., T. C. Kelly, and C. Assad

1978 The Fort Sam Houston Project: An Archaeological and Historical Assessment. Center for Archaeological Research, The University of Texas at San Antonio, Archaeological Survey Report 40. 
GouTd, S.

1882 The Alamo City Guide, Historical Sketch of the City of the Alamo. Macgow \& S1 ipper (Printers), New York.

Hal1, G. D.

1977 U.T. Austin - Site Survey Form. Historic Mill, Kerrville Reservoir Project, site no. 41 LR 130. On file, Texas Archeological Research Laboratory, Austin.

Herff, F. P.

1973 The Doctors Herff: A Three Generation Memoir. Trinity University Press, San Antonio.

Hester, T. R.

1980 Digging Into South Texas Prehistory: A Guide for Amateur Archaeologists. Corona Publishing Company, San Antonio, Texas.

Howard, M. A.

1985 National Register of Historic P1aces Nomination Form for William Thompson Dam and Millrace Site. On file, Texas Archeological Research Laboratory, Austin.

Howe11, C.

1982 Letter to Lois Flynn, February 16, 1982. On file, Center for Archaeological Research, The University of Texas at San Antonio.

Hurst, R. B., translator

n.d. Literal Translation of Diary and Letters of Carl Hilmar Guenther. Unpublished manuscript on file at the Daughters of the Republic of Texas Research Library at the Alamo.

Jackson, A. T.

1971 Mills of Yesteryear. Texas Western Press, University of Texas at E1 Paso.

n.d. A. T. Jackson Papers. University of Texas Archives, Barker Texas History Center, The University of Texas at Austin.

James V. L.

1938 Frontier and Pioneer Recollections of Early Days in San Antonio and West Texas. Artes Graficas, San Antonio. 
Jeane, G.

1979 Archival and Fjeld Survey of McCosh's Mill, West Point Lake, Alabama. Auburn University, Department of Geography, Auburn, Al abama.

Koch, A.

1873 Bird's Eye View of the City of San Antonio, Bexar County, Texas, 1873. Reproduced from the collection of the San Antonio Museum Association. Published by R. H. Holland.

1886 Bird's Eye View of San Antonio, Texas, 1886, Looking North East. Reproduced from the collection of the Randolph Blueprint Company, San Antonio.

Kuhlmann, C. B.

1973 The Development of the Flour-Milling Industry in the United States. Reprint of 1929 edition. Augustus M. Kelly, New Jersey.

Land and Thompson, publishers

1885 Historical and Descriptive Review of the Industries of San Antonio, 1885. San Antonio.

Lauderdale, R. J. and J. M. Doak

1936 Life on the Range and on the Trail. Naylor Publishing Company, San Antonio.

Leutenegger, Fr. B. and Fr. M. Habig

1977 Journal of a Texas Missionary, 1767-1802, 01d Spanish Missions. Historic Research at San José Mission, Documentary Series 3, San Antonio, Texas.

Martinez, A.

1819 Report to the Viceroy concerning the July 5th Flood. Bexar Archives Microfilm Roll 63. John Peace Library, The University of Texas at San Antonio, San Antonio, Texas.

McEachern, M. and R. W. Ralph

1981 Archeological Investigations at the Thomas F. McKinney Homestead, Travis County, Texas: An Experiment in Historical Archeology Part II. Bulletin of the Texas Archeological Society 52:5-63. 
Metcalf and Eddy, Consulting Engineers

1920 Report to City of San Antonio, Texas, upon Flood Prevention. Copy in files of Center for Archaeological Research, The University of Texas at San Antonio.

Morrison, A.

1887 San Antonio: Her Prosperity and Prospects. George W. Engelhardt, St. Louis, Missouri.

Parsons, M. and R. E. Burnett

1984 Landmark Inn State Historic Site, Archeological Investigations, Medina County, Texas, 1975-1980. Texas Parks and Wildlife Department, Historic Sites and Restoration Branch.

Reilly, J. S.

1885 San Antonio, Texas, Past, Present and Future. Private7y published, San Antonio.

Reynolds, J.

1970 Windmills and Watermills. Praeger Publishers, New York.

San Antonio Express

1913 Heavy Flooding. October 2, 1913:1, San Antonio, Texas.

Dam the 01mos. October 2, 1913:Editorial Page, San Antonio, Texas.

The Waste of Water. Friday Morning, October 3, 1913:Editorial Page, San Antonio, Texas.

1921 San Antonio River Floods. September 11:1, San Antonio, Texas.

River Rise Brings Widespread Loss. September 11, 1921, San Antonio, Texas.

1926 01d Mill Wrecked to Straighten the River. August 26, 1926, San Antonio, Texas.

San Antonio Herald

1865 House for sale advertisement in issue of September 9, 1865. 
San Antonio River Authority (SARA)

1969 Flood Plain Information, Salado Creek, San Antonio, Texas. Prepared for SARA by the Department of the Army, Corps of Engineers, Fort Worth District, October.

1970 The San Antonio Channel Improvement Project. An Intergovernmental Effort to Reduce Flooding in the San Antonio Metropolitan Area. A Status Report. July 1970.

1980 The San Antonio Channel Improvement Project and The Salado Creek Watershed Protection and Flood Prevention Project. An Intergovernmental Effort to Reduce Flooding in the San Antonio Metropolitan Area. A Status Report. September 1980.

1985 Brief History of Flooding in San Antonio and Early Attempts to Correct Problem, SARA Management Report. Manuscript on file, Center for Archaeological Research, The University of Texas at San Antonio.

Sanborn Map and Publishing Company, Ltd.

1885 Map of San Antonio, Texas. New York.

1888 Map of San Antonio, Texas. New York.

1896 Map of San Antonio, Texas. New York.

1904 Map of San Antonio, Texas. New York.

1912 Map of San Antonio, Texas. New York.

1924 Map of San Antonio, Texas. New York.

Schuchard, E.

1951 100th Anniversary, Pioneer Flour Mills, San Antonio, Texas, 1851-1951. Naylor Publishing Company, San Antonio.

Scurlock, D., A. Benavides, Jr., D. Isham, and J. W. Clark, Jr.

1976 An Archeological and Historical Survey of the Proposed Mission Parkway, San Antonio, Texas. Office of the State Archeologist, Texas Historical Commission, Archeological Survey Report 17.

Southern Moving and Storage Co.

1970 San Antonio River--Once "The $01 d$ Mill Stream." One in a Series of Little Known Historical Sketches of Texas and San Antonio. San Antonio. 
Southwest Research Institute

1979 Environmental Resource Evaluation of Unit 7 of San Pedro Creek and 8-3 Units of the San Antonio Channel Improvement Project, San Antonio, Texas. Draft Final Report. Department of Environmental and Resource Engineering, Southwest Research Institute. April 1979. San Antonio.

Storck, J. and W. D. Teague

1953 Flour for Man's Bread. University of Minnesota, Minneapol is.

Turner, E. S. and T. R. Hester

1985 A Field Guide to Stone Artifacts of Texas Indians. Texas Monthiy Press, Austin.

United States Department of the Interior, Office of the Census

1870 The Ninth Census, 1870. Returns of Schedule One, Population. Government Printing Office, Washington, D.C.

Wangler, Msgr. A. C.

1974 Archdiocese of San Antonio, 1874-1974. Archbishop of San Antonio, Texas.

Webb, W. P., editor

1952 The Handbook of Texas. 2 vols. The Texas State Historical Association, Austin.

Wimberley, C. W.

1965 Stone Milling. Von Boeckmann-Jones Company, Austin.

Zimiles, M. and M. Zimiles

1973 Early American Mills. Clarkson N. Potter, Inc., New York. 


\title{
APPENDIX I. THE ARTIFACTS
}

\author{
Anne A. Fox
}

\section{INTRODUCTION}

Taken as a whole, the artifacts from the Guenther Upper Mill site excavations are suggestive of a late 19th-century home site. This is peculiar, since the site was occupied only by various industrial operations until ca. 1935. Investigations at other mill sites have yielded comparatively few domestic type artifacts such as ceramic sherds, glass containers, and personal items (see Durrenberger 1965 and Parsons and Burnett 1984). Most of this domestic material was found in the top two or three levels of all units, which were identified at the beginning of the excavations as fill probably brought in after the 1926 demolition and/or during landscaping efforts in connection with the Goldstein House. The fill was first identified in Unit 1 where it was found to overlie the remains of the demolished mill foundation. The identification was confirmed in other units on both the lower and upper terraces where it was similar in color, texture, and artifactual content. Once the crew was sure of the homogeneity of this layer across the site, the first fill layer was usually removed by the archaeological crew without screening, artifacts being collected as they were encountered. Layers identified either in the field or later in the laboratory as being fill are so indicated on the provenience table (Table 2). In several instances the probability of Layer 3 being fill was established by matching sherds of the same vessel in Layers 1 or 2 with one in Layer 3.

Description of the artifacts will be done by categories in order to demonstrate the uses to which one might reasonably expect them to be put. Table 2 also groups the artifacts by the structure being investigated.

\section{CERAMICS}

Unglazed ceramic sherds were from flower pots. With one possible exception, they all came from the fill. There were two sherds from Mexican-made leadglazed pots (Fig. 30,a) of a type popular from the 1750 s to the present day in south Texas. They are therefore not datable, but would seem to relate to kitchen, and therefore to domestic, functions. Several sherds of Mexicanmade tin-glazed earthenware popularly called majolica were found (Fig. 30,b). One blue on white sherd typical of the 18th century from the lower terrace, had been rounded by tumbling in the river and no doubt washed downstream from some other location. Two other sherds, although also blue on white, had the rim band and hard, red paste typical of later Mexican majolicas and could date anytime after the early 19 th century. These sherds came from Unit 9, Layer 8 .

White earthenwares decorated in various ways were particularly popular in the San Antonio area between 1830 and 1850 (Fox 1986). These early types are represented by six sherds. Two sherds that came from the lower terrace, one with a blue transfer design (Fig. 30,g) and one blue edged ware (Fig. 30,C), have also been noticeably rounded and probably washed in. Three matching hand-painted sherds, aTthough not as obviously tumbled, were found on the 
TABLE 2. PROVENIENCE OF ARTIFACTS

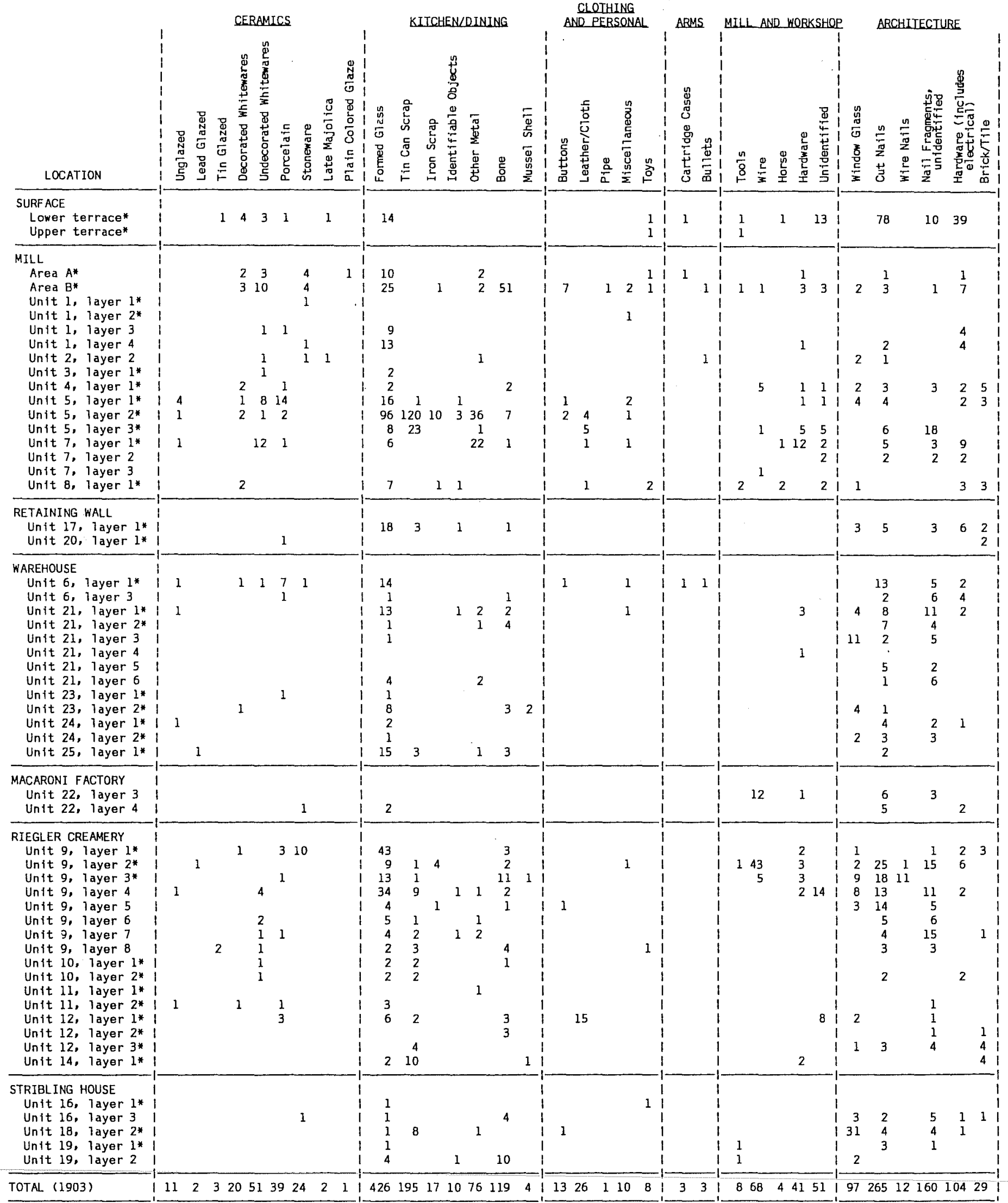


lower terrace and could have come from river deposits. A blue spattered sherd (Fig. 30,d) found in Unit 11, Layer 2, was in the fill. The other decorated sherds (Fig. $30, e, f, h, j, k$ ) bear patterns generally found on mid-toTate-19th-century sites in San Antonio, and were also in the fill deposits.

Undecorated whitewares as a category include both earthenwares and the harder-paste ironstone wares as well as numerous gradations in between. After the Civil War, San Antonio housewives replaced their decorated wares with plain, white ironstone, some with molded decoration. Also popular during this period and lasting into the early 20th century were plain white earthenwares. Of the 51 recovered sherds classified as undecorated whitewares, $82 \%$ came from the fill layers. A sherd collected from the surface of the lower terrace bears the mark of Knowles, Taylor and Knowles (Fig. 30,1), who made ironstone from about 1872 to 1900 (Ramsay 1976:216).

Plain white porcelain plates, cups, and saucers were popular in the late 19th century, especially in more well-to-do households. Of the 39 porcelain sherds, 37 or $95 \%$ came from the fill. Also among these were seven from two saucers with a decalcomania design of roses over-painted with touches of gold (Fig. 30,i). Such decoration on porcelain was very popular in fashionable San Antonio households at the turn of the century.

Twenty-four stoneware sherds too small to be identified as to vessel shape were also recovered primarily from the fill. Two sherds of Victorian majolica, a tin-glazed earthenware made in the last half of the 19th century (Ray 1974:129) were also present, and one earthenware sherd with plain blue glaze on both sides typical of the 1920 s era was found in clearing Area $A$.

\section{KITCHEN/DINING ARTIFACTS}

Formed glass container sherds, of which 317 or $74 \%$ were from the fill, were represented by 426 sherds from 01 ive and black glass wine bottles, brown whiskey and medicine bottles, aqua soda bottles and clear glass medicine bottles (Fig. 31,a,c,e), flavoring bottles (Fig. 31,d), food storage jars, and milk bottles. A milk bottle sherd from Layer 4 of Unit 9 was found to be from a bottle marked "REIGLER'S SAN ANTONIO" accompanied by a winged cherub holding a bow (Fig. 31,b). Layer 4 was below the fill and probably was undisturbed. Sherds of milk glass ointment jars and a few fragments of pressed glass tumblers and other vessels (Fig. 32,a-d,f,g) were also present.

Numerous fragments of thin rusted metal were categorized for convenience as tin can scrap, since that appeared to be the origin of most of it. Although this sort of metal was scattered throughout the site, the largest amount was found in the deep layers of fill in Unit 5 at the southeast corner of the mill basement. Generous amounts of formed glass and other kinds of metal were also in this deposit.

Iron scrap consisted of fragments of cast iron that appeared to have been from kitchen utensils of various kinds. Other metal included a brass washer, and unidentifiable fragments of lead, copper, and alloys of various types. Recognizable metal objects that could be directly related to this category 
included a silver-plated metal table knife (Fig. 32,e) from Unit 19, Layer 2, (the Stribling House), and an iron bottte opener from Unit 8, Layer 1.

A comparatively small amount of animal bone was found in the deposits. This was mostly cow and chicken bone, plus a number of small bird, rodent, and turtle bones that were probably from creatures native to the river bank. Four mussel she11 fragments were too small to properly identify.

\section{CLOTHING AND PERSONAL OBJECTS}

Five shell buttons ranging in diameter from $10 \mathrm{~mm}$ to $15 \mathrm{~mm}$ were found in the fill layers. Metal buttons $19 \mathrm{~mm}$ in diameter were recovered, six from Area B and one from Unit 9, Layer 5.

Fragments of cloth and leather were arbitrarily classified as clothing. Most of the leather was comparatively heavy and appeared to be shoe fragments. A few thin fragments from Unit 5, Layer 3, may possibly be part of a chamois used in the garage operations. A11 came from fill deposits. One piece of heavy knitted cloth appeared to be a charred section of a sock. In Layer 1 of Unit 12 were 15 fragments of a stiff, very fine linen such as was used for architectural drawings and other documents in the 19th century. There was no evidence of markings on either surface, however.

A fragment of a molded red clay smoking pipe with orange glaze was recovered from Area B (Fig. 33,f). Similar pipes are common in late-19th-century sites in San Antonio and el sewhere.

Under the miscellaneous category are included two U.S. pennies, one from Layer 1 of Unit 7, which is dated 1975 and one from Layer 2 of Unit 1, which is dated 1965. A cointike good luck piece was found in Layer 1 of Unit 1 (Fig. 33,a). Two slate fragments were found in the fill in Units 5 and 6 . A sma11 pocket knife came from Area B (Fig. 33,i), and part of a drawing compass came from Layer 2 of Unit 5 (Fig. 33,j). A smal1 hinged rouge compact with a mirror inside the 1id (Fig. 33,d) from Layer 1 of Unit 21 could date to the 1930s, while a bone toothbrush fragment (Fig. 33,h) from Layer 1 of Unit 5 was probably used closer to the turn of the century according to observations of recent excavations in downtown San Antonio. Half of a wooden spool for sewing thread came from Layer 2 of Unit 5 (Fig. $33, \mathrm{c})$.

Toys recovered are mainly glass marbles of uncertain age. Also found were a small plastic fish from the surface of the upper terrace and a glazed porcelain doll's arm from Unit 9, Layer 8 (Fig. 33, k). The latter probably dates to the late 19th century. Fragments of dolls' dishes found in the fill include half of a plain white porcelain saucer and three sherds from a porcelain tea pot with green, white, and lavender underglaze painted decoration (Fig. 33,1). An imitation coin (Fig. 33,b) inscribed "PLAY DOUGH" came from Layer 1 in Unit 8. 
Figure 30 . Ceramics.

a, lead-glazed Mexican ware;

b, tin-glazed majolica, 18th century;

$c$, blue-edged ware;

d, blue-spattered ware, early to mid-19th century;

e, brown transfer ware, late 19th century;

$f$, green transfer ware, 1ate 19th century;

$\mathrm{g}$, blue transfer ware, 1ate 19th century;

$h$, blue painted edge ware, 1ate 19th century;

$i$, decalcomania and hand-painted porcelain, late 19th century;

$j$, hand-painted ironstone, mid-19th century;

$k$, late version of banded slip ware, blue green on cream, late 19th century;

1, ironstone, maker's mark: KNOWLES, TAYLOR AND KNOWLES, late 19th century. 


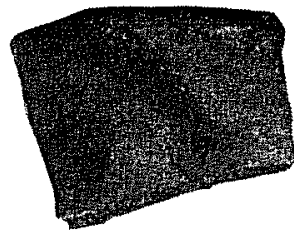

a
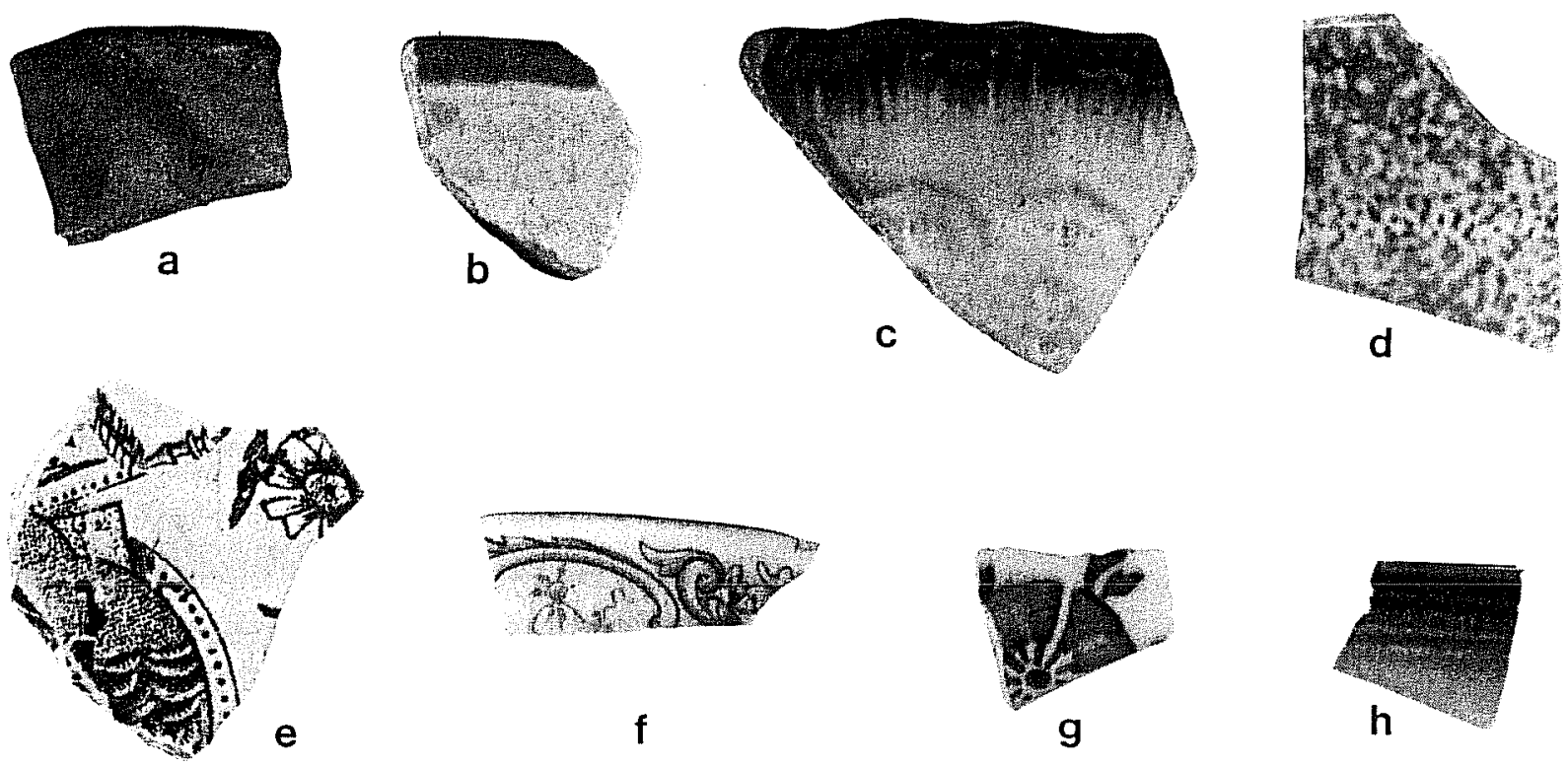

f
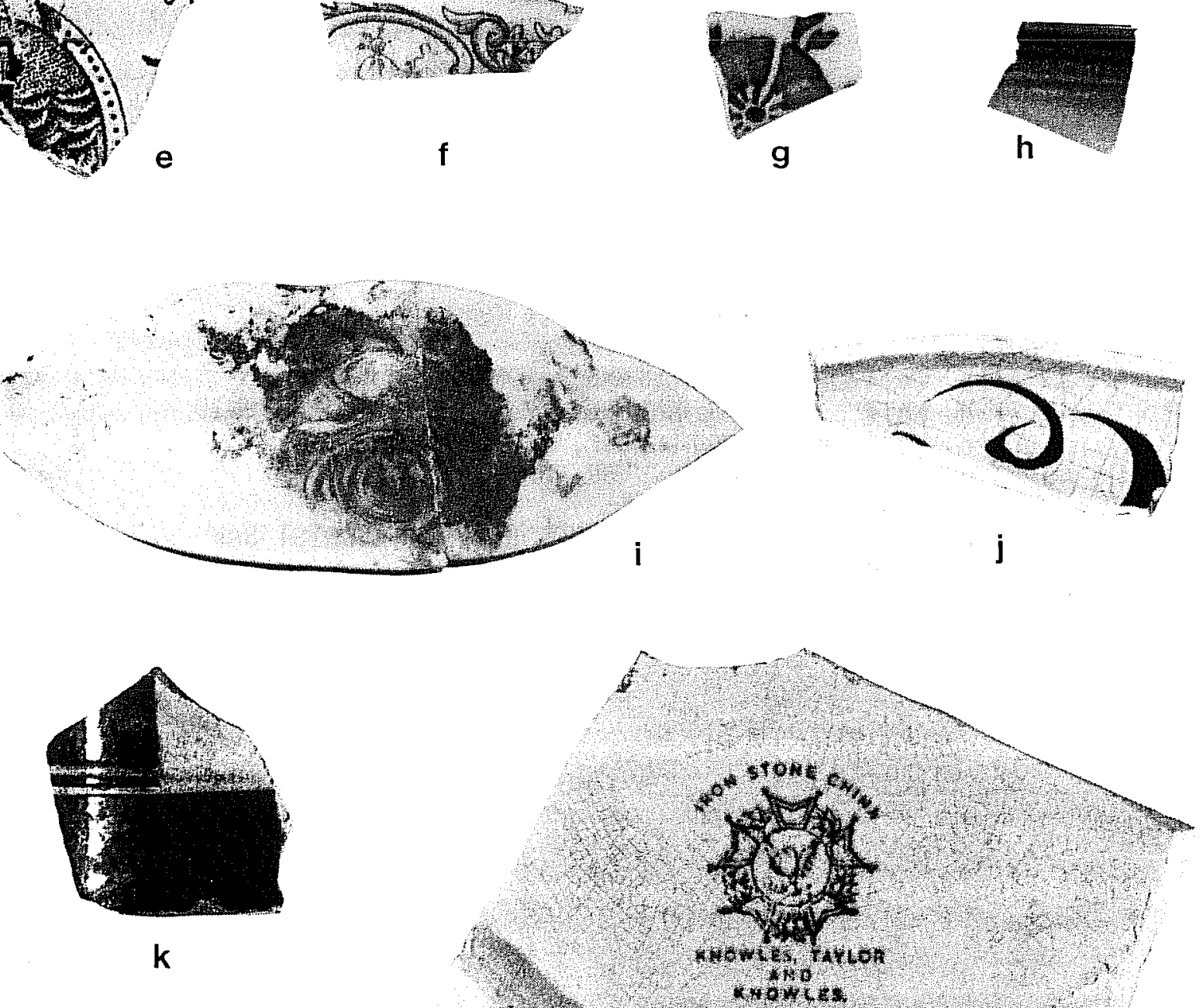

$\mathrm{cmL}_{1}+1,1,1,1,1$ 
Figure 31. Glass Containers.

a, cylindrical container, no marks;

b, half pint milk bottle, "RIEGLER'S SAN ANTONIO";

c, cylindrical container, no marks;

d, flavoring bottle, "DR. PRICE'S DELICIOUS FLAVORING EXTRACTS";

e, medicine bottle, "A. NETTE, JR. DRUGGIST SAN ANTONIO," ca. 1877. 
CHANNEL IMPROVEMENT / Appendix I

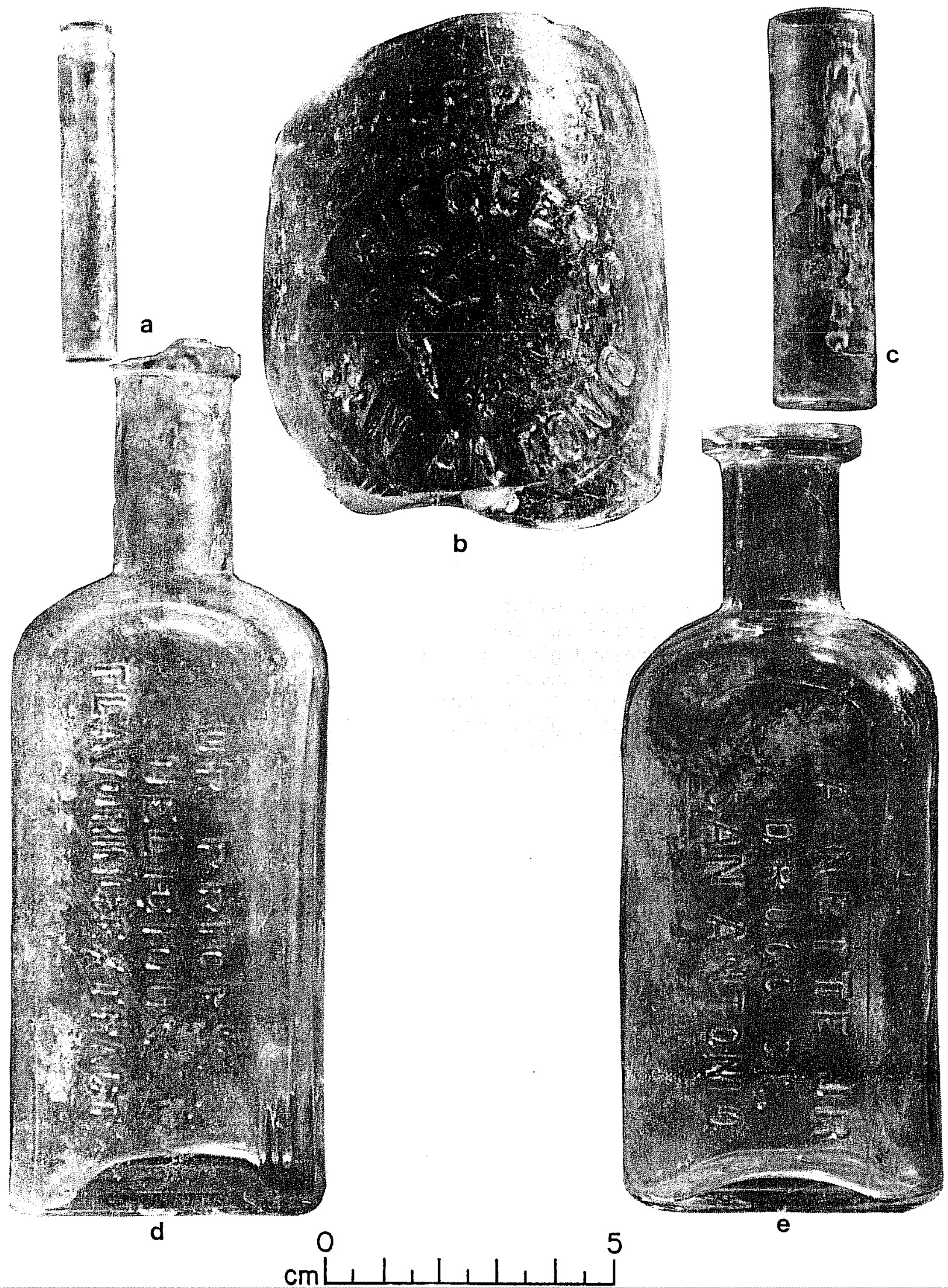


Figure 32. Tablewares.

a, pressed glass tumbler;

b, fluted tumbler;

$c$, pressed glass cylindrical vessel;

d, fluted tumbler;

e, silver-plated table knife;

$f$, frosted glass decorative globe or jar;

$\mathrm{g}$, pressed glass bow1. 


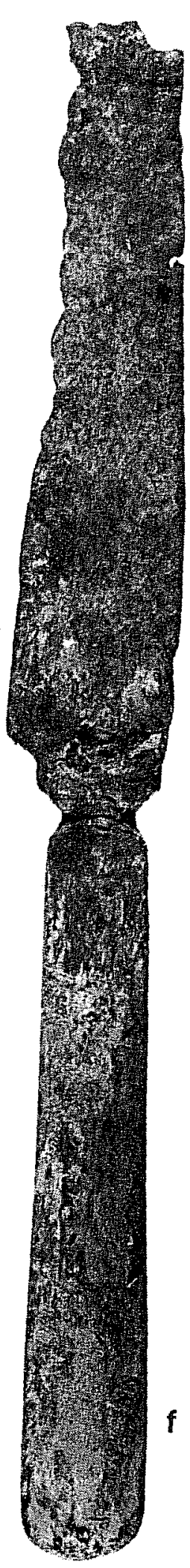

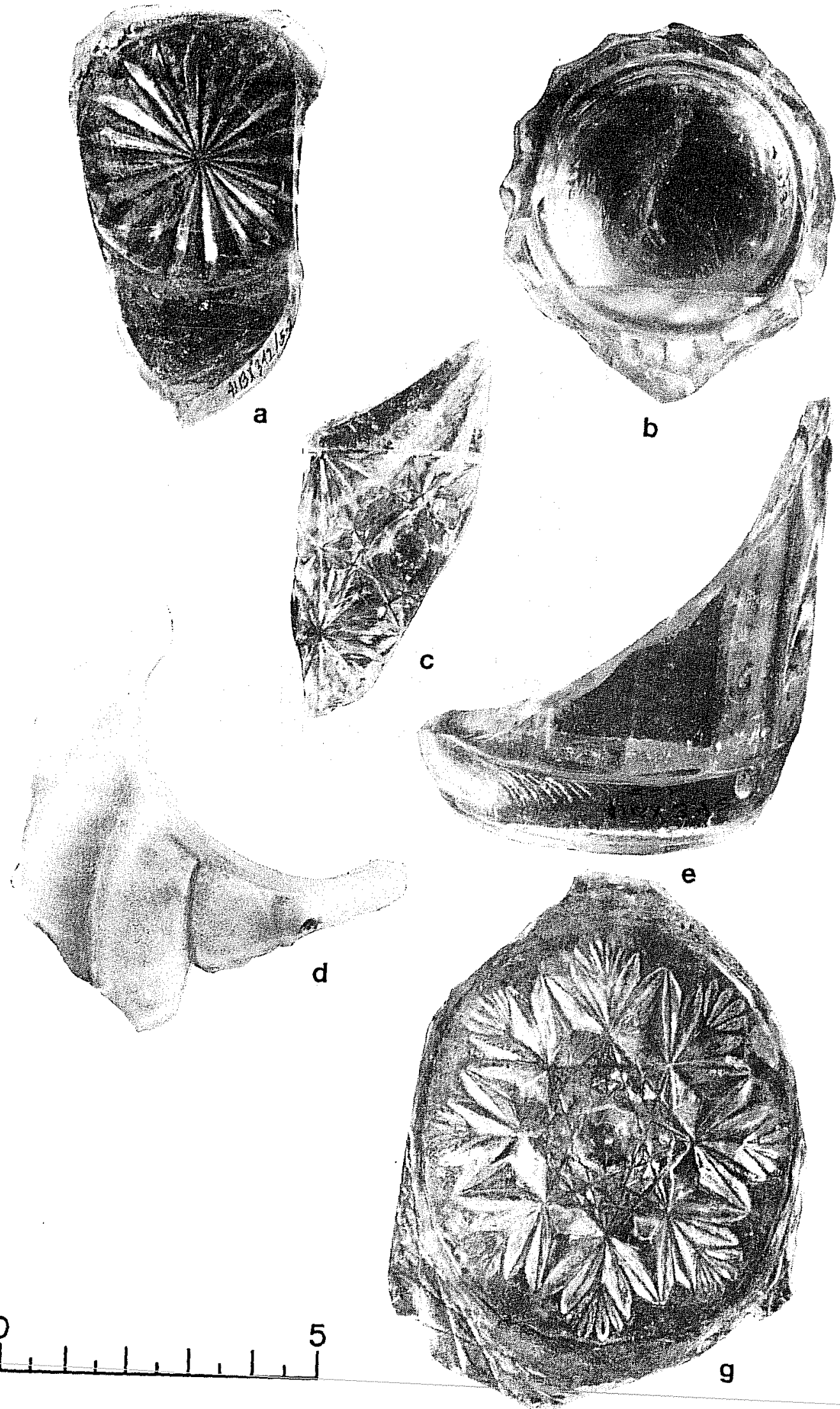


Figure 33. Miscellaneous Small objects.

a, good luck piece, "GOOD LUCK WILL ACCOMPANY THE BEARER";

b, toy coin;

c, wooden spool;

d, rouge compact;

e, brass fitting, possibly for carriage or automobile;

$f$, glazed red clay pipe fragment;

$g$, stamped brass fragment;

$h$, bone toothbrush fragment;

$i$, pocket knife;

$j$, drawing compass;

$k$, porcelain doll's arm;

T, porcelain toy tea pot fragment;

$\mathrm{m}$, glazed porcelain insulator;

$n$, unglazed porcelain insulator. 


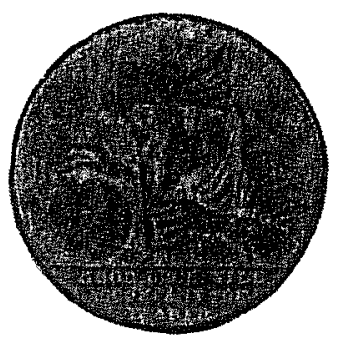

a

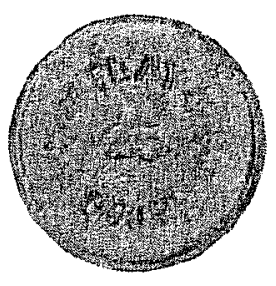

b

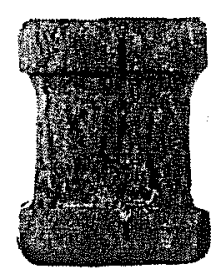

C

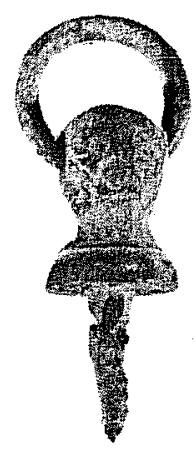

e

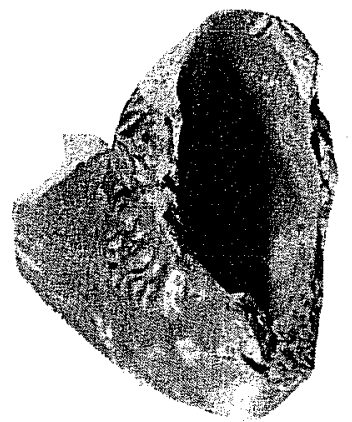

f
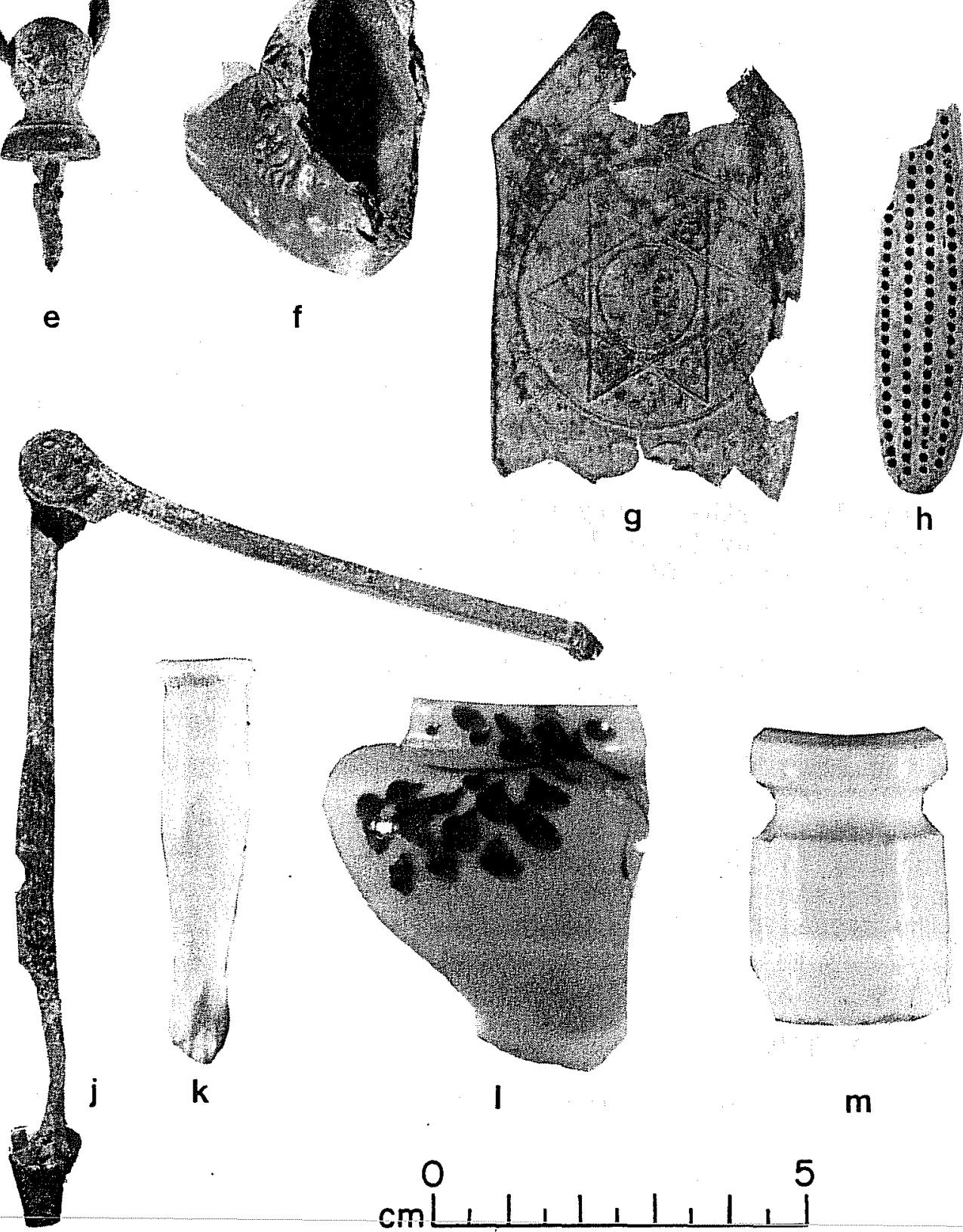

$\mathrm{cm}+1,1,1,1,1$

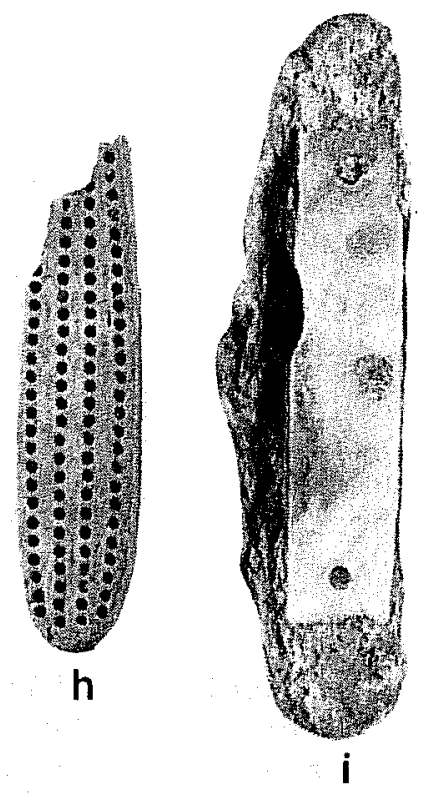

d

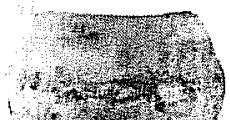

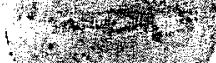

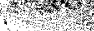

\%
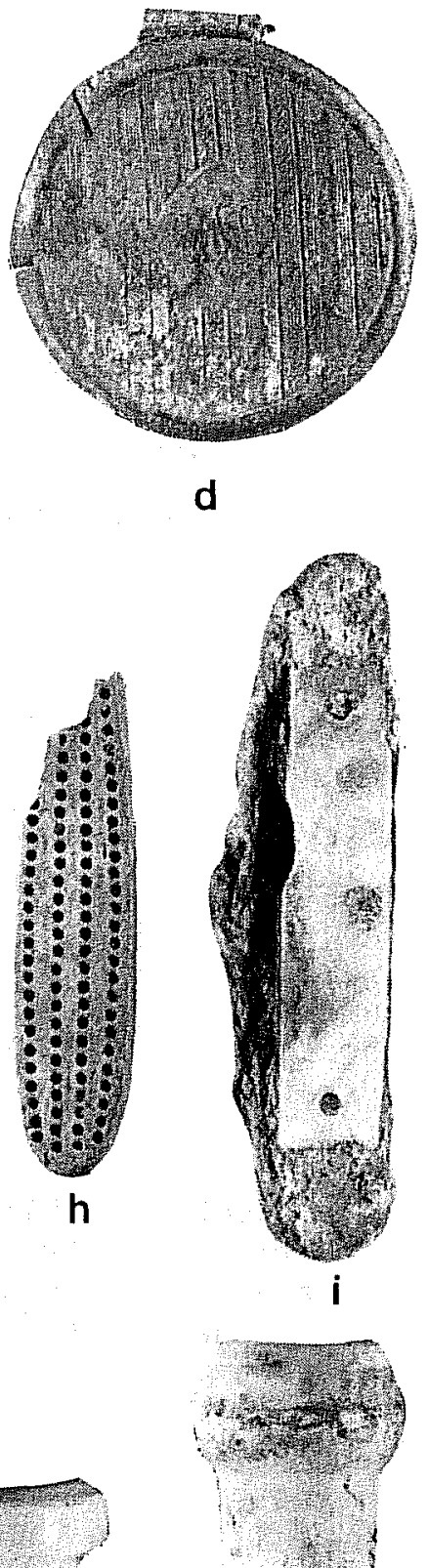

n
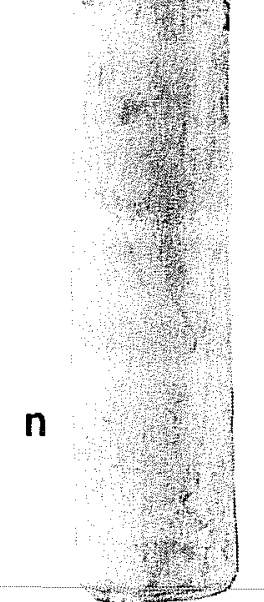


\section{ARMS}

The following objects were identified by Robert Harrison of the Center staff:

12 gauge shotgun she11 from Area A

ba110on head pistol she11 from Unit 6 , Layer 1

25 gauge automatic Colt pistol bullet from Area B

.44 or .45 caliber pistol bullet from Unit 6 , Layer 1

.38 caliber pistol bullet from Unit 2, Layer 2

.32 caliber pistol shell from the lower terrace surface

\section{MILL AND WORKSHOP ITEMS}

Identifiable tools are a 1920s automobile wrench (Fig. 34,b) from Layer 1 of Unit 8 , a heavy wedge (Fig. 34,e) from the surface of the upper terrace, and a broken chisel (Fig. 34,d) from Unit 9, Layer 2. A gimlet with a metal handle came from Area B.

Numerous scraps and fragments of wire of various descriptions were found throughout the excavations. Undoubted7y some was debris from the garage operations on the site. There were also a few fragments of coated electrical wire.

Consistent with the 1ate-19th-century date of the fill were three fragments of horseshoes, one each from Layer 1 of Unit 8, Layer 1 of Unit 7, and the surface of the lower terrace. Of course, horseshoes could just as well have been connected with the mill activities.

Pieces of metal recognizable as mill or workshop hardware are heavy bolts, automobile parts (Fig. $33, \mathrm{e}, \mathrm{g}$ ), metal rings and washers of various sizes, pieces of rubber hose, and a metal wire spool. These were spread throughout the fill and in the lower deposits as well.

Unidentified tools (Fig. 34,C) and machine parts (Fig. 34,a) of heavy iron were found primarily in the excavation of units around the mill proper, particularly on the lower terrace. There were also numerous pieces of heavy iron in among the stones removed from the forebay and wheel pit, that could have been parts of the mill machinery.

\section{ARCHITECTURE-RELATED ITEMS}

Window glass was found throughout the site both in the fill and below. It was consistently ca. $2 \mathrm{~mm}$ in thickness, except for a few fragments of heavy mirror glass $5 \mathrm{~mm}$ thick with reflective coating on onn farn from llnit 9, Layer 1. 
Machine cut nails were present in nearly every layer excavated. Since there were only 12 wire nails found during the excavations, it is probable that most of the unidentifiable fragments were also from cut nails. These are equally as likely to have come from the mill as from the fill material, since wire nails came into popular use ca. 1900 in San Antonio.

Architectural hardware from the site are screws, common door hinges and 1 atch parts, porcelain electrical fixtures and insulators (Fig. 33,m,n), and light bulb parts. They came from both fill and lower layers, primarily on. the upper terrace.

Fragments of six different colors of brick were found during the excavations. These ranged in hardness from a tan fragment of firebrick from Layer 1 of Unit 5, to a very soft yellow fragment from Layer 1 of Unit 4 which has nearly disintegrated after drying out in the laboratory. With the exception of a small piece of red brick from Layer 4 of Unit 9, and a yellow brick from the Stribling House, all of this appears to have been deposited with the fill and probably does not relate to the mill site.

Pieces of bathroom tile probably from residential construction were found in Layer 1 of Unit 8, Layer 1 of Unit 17, and Layer 3 of Unit 16. The first two probably came from the demolition of the Goldstein House, while the latter, a sma11, hexagonal porcelain tile, was once installed in the Stribling House. Fragments of glazed sewer tile were found in Unit 20, and unglazed drainage tile came from Layer 1 of Unit 14.

\section{SUMMARY}

After the demolition of the mill, little structure remained above the surface, and apparently the entire area was covered with a deposit of fill brought in from a late-19th-century residential site. Proof of the origin of this fill can be established by examination of its contents. The following list of artifacts from the fill confirms its residential character as well as its late-19th-century date:

unglazed ceramic flower pots undecorated white earthenwares 1ate-19th-century transfer patterns white porcelain decal-decorated porcelain stoneware utility vessels Victorian majolica wine bottles brown and aqua beverage bottles clear glass food storage jars clear glass medicine bottles milk glass ointment jars pressed glass cast iron vessels she 11 buttons molded ceramic smoking pipe slate fragments bone toothbrush handle ceramic do17's arm ceramic dolls' dishes horseshoes

cut nails

Similar inventories have been recovered from archaeological excavations at other 1ate-19th-century sites in San Antonio and south Texas (Katz 1978; Fox and Cox 1983; Fox 1985). 
Figure 34. Miscellaneous Tools and Machine Parts.
a, unidentified machine part;
b, early automobile wrench;
c, unidentified tool with glazed porcelain inset;
d, broken chisel;
e, iron splitting wedge. 

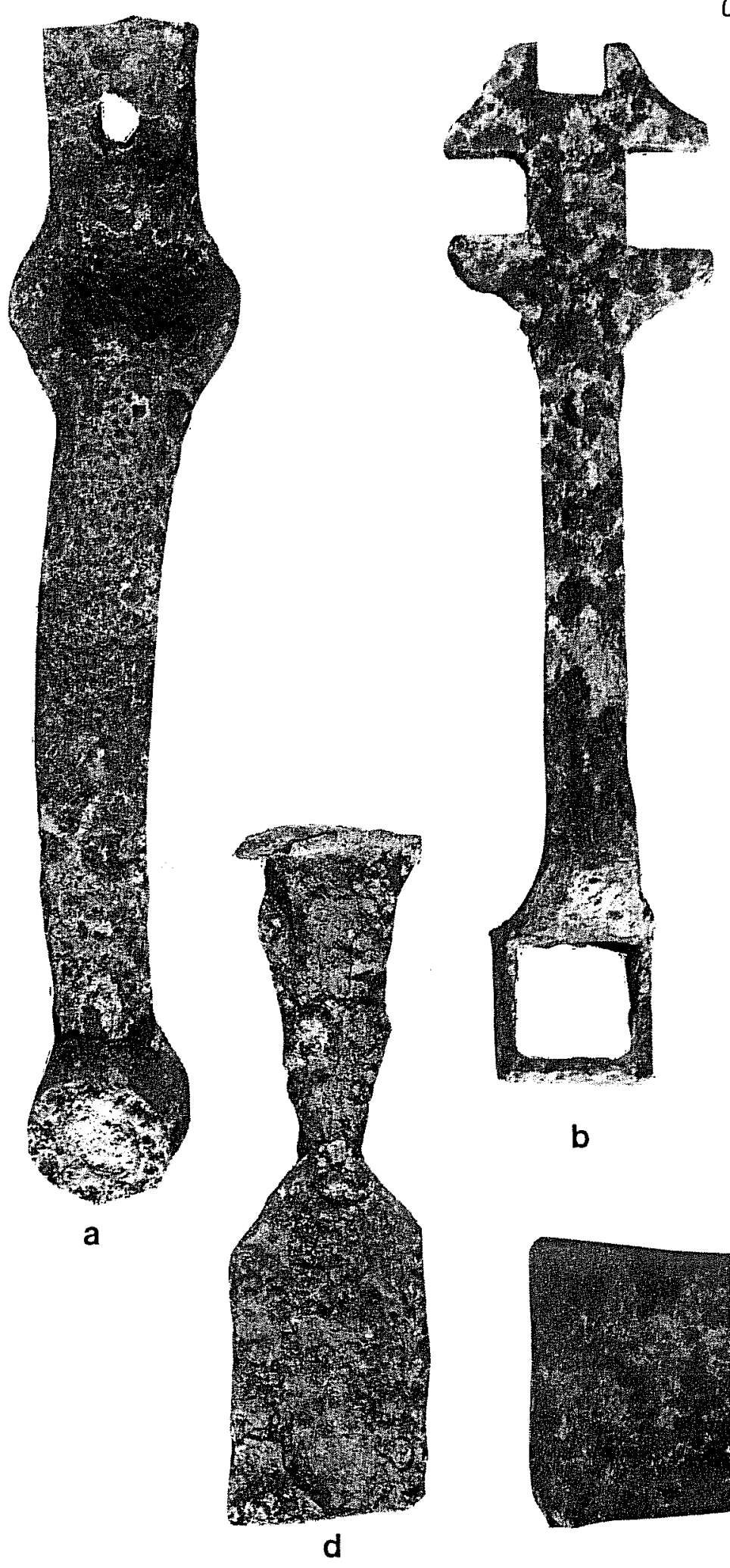

CHANNEL IMPROVEMENT / Appendix I 


\section{REFERENCES CITED}

Durrenberger, E. P.

1965 Anderson's Mi11 (41 TX 130): A Historic Site in Travis County, Texas. Bulletin of the Texas Archeological Society $36: 1-70$.

Fox, A. A.

1985 Testing for the Location of the Alamo Acequia (41 BX 8) at Hemisfair Plaza, San Antonio, Texas. Center for Archaeological Research, The University of Texas at San Antonio, Archaeological Survey Report 142.

1986 Ceramics. In La Villita Earthworks (41 BX 677): San Antonio, Texas. A Preliminary Report of Investigations of Mexican Siege Works at the Battle of the Alamo, assembled by J. H. Labadie:107-127. Center for Archaeological Research, The University of Texas at San Antonio, Archaeological Survey Report 159.

Fox, A. A. and I. W. Cox

1983 Archaeological and Historical Investigations at the Valenzuela Ranch, Dimmit County, Texas. Center for Archaeological Research, The University of Texas at San Antonio, Archaeological Survey Report 126.

Katz, P. R.

1978 Archaeological and Historical Investigation in the Arciniega Street Area, Downtown San Antonio, Texas. Center for Archaeological Research, The University of Texas at San Antonio, Archaeological Survey Report 61.

Parsons, M. and R. E. Burnett

1984 Landmark Inn State Historic Site, Archeological Investigations, Medina County, Texas, 1975-1980. Texas Parks and Wildlife Department, Historic Sites and Restoration Branch.

Ramsay, J.

1976 American Potters and Pottery. Ars Ceramica, Ltd. Ann Arbor, Michigan.

Ray, M.

1974 Collectible Ceramics. Crown Publishers, Inc., New York. 


\section{APPENDIX II. FAUNAL ANALYSIS}

Robert Harrison

\section{INTRODUCTION}

Among the artifacts recovered during archaeological testing at Guenther's Upper Mill site was a moderate quantity of animal bone. Of the 129 bones or bone fragments recovered, preservation is generally good, and the majority are identifiable as to species and gross anatomical location. Most of the bones or bone fragments represent remains of domestic animals. Many of the bone fragments are the result of butchering activities. Evidence of butchering consisted of saw marks or chop marks.

\section{METHODS}

Twenty-five units of various dimensions were excavated. Unit levels were determined by the stratigraphy of a particular unit. In the opinion of the project director (Anne Fox, personal communication) the stratigraphic levels from which the vast majority of faunal remains were recovered represented fill dirt brought in from another location during the 20th century.

Recovered faunal material was given to the author after being washed and labeled as to unit, level, and lot number. Specimens were then sorted by species and gross anatomical location. Identification was made using the faunal collection at the Center for Archaeological Research, The University of Texas at San Antonio.

A11 bones and bone fragments were examined for evidence of human modification, such as butcher marks or the spiral fractures associated with intentional splitting (Gilbert 1980). Butcher marks were noted as to type of mark and location of mark on the bone or bone fragment. Local area butchers were consulted for additional information on butchering techniques, species identification, and cuts of meat represented by many of the bone fragments.

Because of the secondary depositional nature and limited numbers of bones and bone fragments represented, the author did not believe that the calculation of minimal numbers of individuals would be appropriate for this analysis. The nature of the sample precluded analysis for individual age of animals beyond the statement that all bones or bone fragments appear to represent adult animals.

\section{DESCRIPTION OF THE FAUNAL ASSEMBLAGE}

The domestic animals represented among the 41 BX 342 faunal assemblage are cow (Bos taurus), pig (Sus scrofa), and chicken (Gallus gallus). Wild animals include white-tailed deer (Odocoileus virginianus), an unidentified smal1 rodent, and fragments of freshwater mussel she11. Table 3 lists the species, number of bones or bone fragments associated with that species, and cultural significance. 
TABLE 3. SPECIES LIST AND SPECIMEN INFORMATION

\begin{tabular}{|c|c|c|}
\hline Taxon & $\begin{array}{l}\text { Number of } \\
\text { Specimens }\end{array}$ & Cultural Significance \\
\hline $\begin{array}{l}\text { Class Aves } \\
\text { Gallus gallus } \\
\text { (domestic chicken) }\end{array}$ & 4 & None \\
\hline \multicolumn{3}{|l|}{ Class Mammalia } \\
\hline Unidentifiable & 20 & Sma11 fragments or burned \\
\hline $\begin{array}{l}\text { Order Artiodactyla } \\
\text { Bos taurus } \\
\text { (domestic cow) }\end{array}$ & 93 & $\begin{array}{l}49 \text { demonstrate evidence } \\
\text { of butchering ( } i . e . \text {, saw } \\
\text { or cleaver marks); } 44 \text { are } \\
\text { small cranial fragments }\end{array}$ \\
\hline $\begin{array}{l}\text { Odocoileus virginianus } \\
\text { (white-tailed deer) }\end{array}$ & 5 & $\begin{array}{l}\text { A11 demonstrate butcher- } \\
\text { ing marks }\end{array}$ \\
\hline $\begin{array}{l}\text { Sus scrofa } \\
\text { (domestic pig) }\end{array}$ & 1 & None \\
\hline $\begin{array}{l}\text { Order Rodentia } \\
\text { Smal1 rodent }\end{array}$ & 2 & None \\
\hline $\begin{array}{l}\text { Class Mollusca } \\
\text { Freshwater mussel }\end{array}$ & 4 & Probably none \\
\hline
\end{tabular}

Domestic cow (Bos taurus) remains represent the greatest number of specimens from this site. All of these specimens appear to have derived from adult anima7s. Forty-four bone fragments appear to be from the cranium. Fortynine specimens denote the result of butchering activity as evidenced by saw marks or cleaver marks. These are postcranial in origin. Fragments of rib bones were the most common, followed by fragments originating from the hind or forequarters.

White-tailed deer (Odocoileus virginianus) represented the next most common animal. Five fragments of postcranial bone were recovered. Four originated from the hindquarters, and one was a vertebral fragment. All of these fragments demonstrate evidence of butchering. 
Domestic chicken (Gallus gallus) was represented by four femurs. None of these bones demonstrate evidence of knife marks or other butchering activity. The only skeletal material referable to domestic pig (Sus scrofa) was an isolated lower canine tooth. A portion of a mandible and scapula from a small rodent and four fragments of freshwater mussel shell were also recovered.

Among the recovered skeletal material are 20 fragments of bone which are too badly fragmented or burned to identify. Tentatively, these fragments are associated with large- or medium-sized mammals. None of the identifiable bones or bone fragments demonstrate evidence of burning or exposure to high heat.

\section{BUTCHERING PATTERNS}

Forty-three percent of the bones recovered from the Guenther's Upper Mill site show evidence of butchering. Butcher marks on these bones include axe, hatchet, or cleaver cuts visible as deep cuts, sometimes wedge shaped and/or causing local crushing of the bone. Large cleavers are often used by butchers to divide beef carcasses into sides. Saw marks are easily recognized as an extensive smooth or polished surface, often with visible striations. Gust (1983) has compared the saw marks left on bone by handsaws and powered bandsaws. The striations left by handsaws appear more irregular and less smooth than those produced by powered bandsaws.

All of the saw marks visible on the bones or bone fragments recovered from Guenther's Upper Mill site appear to have been produced by a powered bandsaw. Chop marks resulting from axe, hatchet, or cleaver blows are restricted to three specimens: a proximal rib fragment, a vertebral fragment from a cow, and a fragment of white-tailed deer vertebra.

The majority of butchered domestic cow bone fragments are short sections of rib with saw marks on both ends. Also included are bones from the hindquarters. These are two round steak bones, a T-bone steak bone, three marrow bones, and a split fragment of vertebra. With the exception of a vertebral fragment, all of the deer bones are of the round steak variety derived from the hindquarters. The domestic chicken bones are all drumsticks (femurs).

Winkler (1985) analyzed the butchered remains of domestic cattle from an early to mid-19th-century refuse dump in the La Villita area, located in downtown San Antonio. She found that during that period, ribs were generally chopped through, or partially chopped and broken the rest of the way.

\section{DISCUSSION AND CONCLUSIONS}

The faunal assemblage from Guenther's Upper Mill site suggests that the bones and bone fragments represent refuse from domestic cooking activity. This is evidenced by the large number of bone fragments that are the result of butchering and/or represent domestic food animals. Saw marks are of the type produced by a powered bandsaw. This would indicate commercial butchering as 
opposed to domestic butchering and probably dates the bones to no earlier than the latter part of the 19 th century.

Beef was apparently the meat of choice as shown by the large number of cow bone fragments as compared to other animal bones. The paucity of domestic pig remains does not indicate that pork was not eaten. Rather, it is quite probable that pork was eaten in the form of bacon or sausage, which would not produce refuse in the form of skeletal elements.

The number of butchered fragments of deer bone probably represents hunting activity. It is currently normal for many south Texas deer hunters to take their kill to a commercial meat processing plant or local butcher for processing. The evidence of deer bones cut by a bandsaw from Guenther's Upper Mill site suggests that this practice was observed by at least one turn-of-the-century San Antonio household.

Cuts of meat represented by the butchered bones from this site do not differ greatly from those found in a modern middle class San Antonio household. Beef ribs and steaks are popular fare for those able to afford them. Gust (1983) states that bone ends or marrow bones were more popular in the past as the prime ingredients of soups and sauces. Today these bones are sold to pet owners for their dogs.

The faunal assemblage recovered during testing at Guenther's Upper Mill site most likely represents secondary deposition of domestic cooking refuse. The large numbers of bone fragments which demonstrate butcher marks similar to those made by a bandsaw suggest that meat was purchased from a commercial butcher rather than being butchered at home. Cuts of meat and species of animals consumed are not incompatible with a modern middle class San Antonio household.

\section{REFERENCES CITED}

GiTbert, B. M.

1980 Mammalian 0steology. Privately printed, Laramie.

Gust, C. M.

1983 Problems and Prospects in Nineteenth Century California Zooarchaeology. In Forgotten Places and Things: Archaeological Perspectives on American History, edited by A. E. Ward:341348. Center for Anthropological Studies, Albuquerque.

Winkler, A. J.

1985 Preliminary Analysis of Faunal Remains. Manuscript on file, Center for Archaeological Research, The University of Texas at San Antonio. 


\title{
APPENDIX III. MONITORING THE REMOVAL OF WOOD STORED DURING THE EXCAVATION OF GUENTHER'S UPPER MILL SITE
}

\author{
I. Waynne Cox
}

\section{INTRODUCTION}

On January 14, 1986, the Center for Archaeological Research (CAR) was notified by the San Antonio River Authority (SARA) that the contractors for the river channelization were prepared to move the stone and timbers from the storage pit at Guenther's Upper Mill site, in connection with landscaping of the river bank. The timbers had been cribbed and packed in sand since 1982. It was agreed by all parties that the CAR would be contracted to monitor and document their relocation. The author was assigned to monitor and provide photographic documentation of the operation. The work was conducted under the direct supervision of Anne Fox, research associate and laboratory director, and the general supervision of $\mathrm{Dr}$. Thomas R. Hester, Center director, and Jack D. Eaton, associate director.

\section{THE MONITORING}

The stored stone was removed first and deposited within a fenced, secure area along with other cut limestone recovered during the river channelization and landscaping excavations. All were spread out into a single layer so that an assessment of quantity could be made toward their incorporation into any planned reconstruction of the structure.

The mill timbers had been deposited in a shallow pit which was cribbed to a height of approximately eight inches above ground level. The timbers were packed in clean sand and treated with a fungicide. On January 17, 1986, removal of the sand with hand tools began at 8:05 A.M. The first layer of timbers was exposed by 8:30 A.M. They were in excellent condition except for dampness, which had caused some minor surface deterioration to a depth of approximately 1 to $2 \mathrm{~mm}$. Since it had been decided that it would be desirable for the wood to dry slowly, an above-ground location was set aside for their relocation.

The timbers were lifted with double straps by a crane and transported in one operation to the secure area. As each layer was exposed and transported, they were stacked, separated by scrap pieces of 2 inch by 4 inch boards, to form a drying "rick." The lower layers were progressively more water-logged, so that it was necessary to provide sound timber planking for support during their transportation. The final layer of timbers, resting upon a layer of sand only about 30 to $60 \mathrm{~mm}$ above the natural clay subsurface, was in an extremely water-logged and spongy condition. The aggregate of timbers created a rick of four layers, which was covered by black plastic to insure a slow drying condition.

A follow-up inspection, on January 20 , revealed that the timbers were drying as had been planned with no sign of further deterioration. A second inspection, on January 30 , revealed that the drying process was continuing, 
but the timbers that had absorbed the most moisture were experiencing some surface scaling, however, the interior appeared sound. The timbers that had been nearer the top of the original storage showed almost no damage.

\section{RECOMMENDATIONS}

Since the primary factor in the deterioration of the timbers appeared to be moisture, in future operations of this nature, it would appear to be preferable to allow them to slowly air-dry above ground in an enclosed facility. If this is not possible, all efforts to create rapid drainage should be considered. For example, an above-ground crib with a layer of 30 to $35 \mathrm{~mm}$ of gravel at the base, with the timbers enclosed entirely in clean, coarse sand and some form of moisture barrier provided over the top of the structure, would probably be adequate. 